\title{
Predicting inflation, and the relationship between financial integration, financial *development and economic *growth
}

\author{
Lillian T. Kamal \\ West Virginia University
}

Follow this and additional works at: https://researchrepository.wvu.edu/etd

\footnotetext{
Recommended Citation

Kamal, Lillian T., "Predicting inflation, and the relationship between financial integration, financial *development and economic *growth" (2006). Graduate Theses, Dissertations, and Problem Reports. 4238.

https://researchrepository.wvu.edu/etd/4238

This Dissertation is protected by copyright and/or related rights. It has been brought to you by the The Research Repository @ WVU with permission from the rights-holder(s). You are free to use this Dissertation in any way that is permitted by the copyright and related rights legislation that applies to your use. For other uses you must obtain permission from the rights-holder(s) directly, unless additional rights are indicated by a Creative Commons license in the record and/ or on the work itself. This Dissertation has been accepted for inclusion in WVU Graduate Theses, Dissertations, and Problem Reports collection by an authorized administrator of The Research Repository @ WVU. For more information, please contact researchrepository@mail.wvu.edu.
} 
Predicting Inflation, and the Relationship Between Financial Integration, Financial Development and Economic Growth

\author{
Lillian T. Kamal
}

Dissertation submitted to the College of Business and Economics at West Virginia University in partial fulfillment of the requirements for the degree of

\author{
Doctor of Philosophy \\ In \\ Economics
}

\author{
Ronald Balvers, Ph.D., Chair \\ Ashok Abbott, Ph.D. \\ Arabinda Basistha, Ph.D. \\ Alexei Egorov, Ph.D. \\ Kern Kymn, Ph.D. \\ Department of Economics
}

Morgantown, West Virginia, 2006

Keywords: Forecasting, Inflation, Financial Integration, Financial Development, Economic Growth, Development. 


\section{ABSTRACT \\ Predicting Inflation and the Relationship between Financial Integration, Financial Development and Economic Growth \\ Lillian T. Kamal}

Three essays are presented. The first essay re-visits the P* model (developed by Hallman, Porter and Small, 1991) with an application to US data. The central idea behind the $\mathrm{P} *$ model is that the price level is determined by the money stock, output and velocity. This study brings together criticisms of the $\mathrm{P}^{*}$ model together in an attempt to address the major concerns with an improvement upon the existing model. A horse race is then run between the original $\mathrm{P}^{*}$ model, two variant $\mathrm{P}^{*}$ models, and three other models - an atheoretic naïve AR process and an ARMA process as well as a standard output gap type model (the Phillips curve approach). The results show that the $\mathrm{P}^{*}$ approach modeled using a Hodrick Prescott filter marginally out-performs all the other models of inflation in terms of forecast accuracy, suggesting that it may be more useful for inflation-targeting purposes. The results indicate that models based on past information cannot outperform the more sophisticated $\mathrm{P}$-type models. The second essay looks at the relationship between financial development and growth from a developing country perspective, while controlling for financial repression. The proxy of choice is the ratio of currency outside the banking system $(\mathrm{CB})$ to real output. The empirical results show that $\mathrm{CB}$ relates negatively to growth in countries that are less financially liberalized and positively with growth in countries that are more financially liberalized. An innovative measure of financial repression is then proposed that combines the use of currency inside banks and currency outside banks, and is tested concurrently with a broad money depth measure. The study concludes that there is overwhelming evidence that financial repression, which is indicative of financial under-development is negatively related to growth. The final essay implements an innovative approach that examines the impact of financial integration on financial development, and subsequently on economic growth within a sample of EU countries. The study looks at bank-based measures of financial development in an effort to establish whether a relationship exists between financial development and growth in the European Union countries, and if so, whether this relationship has been affected by financial integration. The results support the hypothesis that the benefits of economic and financial integration are not uniform. 


\section{Dedication}

This dissertation is dedicated to my parents, and family, without whose love, support and encouragement, I could never have made it this far. Thank you always - you are my strength.

\section{Acknowledgements}

I would like to thank the following people, without whom this work would not have been possible. To my parents, Kamru and Ranu, and my brother and sister, Sameer and Susie, for their endless love, support and encouragement, and for giving me the opportunity to

pursue this degree. Professor Ron Balvers, who has had endless patience with me in the completion of this project, and who has provided me with invaluable support and guidance throughout this process. I could not have had a better dissertation supervisor, professor and mentor. Professors Abbott, Basistha, Egorov and Kymn - many thanks for being such a wonderful committee and for all your excellent comments and guidance. To

Professor Hassan Arvin-Rad at Northwestern University, who gave me many useful econometric comments. Christine Harrington, for many valuable comments, and for being such a good friend. And last, but certainly not least, John Hagen, for patiently answering all my endless questions on preparing this manuscript for ETD submission, and for being the best friend anybody could ask for. Go Mountaineers! 


\section{Table of Contents}

\section{Chapter 1}

On Refining the Traditional P* Model of Inflation Forecasting

Page 1

Theory

Page 3

Data and Methodology

Page 8

Results

Page 10

Robustness tests

Page 15

Conclusion

Page 21

Appendix 1

Page 24

Appendix 2

Page 25

Appendix 3

Page 26

\section{Chapter 2}

Re-examining the Relationship Between Financial Development and Growth - A Developing Country Perspective

Page28

Theory

Page 29

Methodology

Page 35

Results

Page 41

Robustness tests

Page 43

Conclusion

Page 46

Appendix 1

Page 50

Appendix 2

Page 52

Appendix 3

Page 61

\section{Chapter 3}

The effect of Financial Integration on Financial Development and Growth: A Case Study of the European Union 
Theory

Page 64

Methodology

Page 69

Results

Page 75

Robustness tests

Page 84

Conclusion

Page 85

Appendix 1

Page 89

Appendix 2

Page 91

Appendix 3

Page 93

Appendix 4

Page 94 


\section{Chapter 1}

\section{On Refining the Traditional P* Model of Inflation Forecasting}

\footnotetext{
This paper re-visits the $\mathrm{P}^{*}$ model (developed by Hallman, Porter and Small, 1991) with an application to US GDP and M2 data from 1959 to 2003 . The central idea behind the $\mathrm{P}^{*}$ model is that the price level is determined by the money stock, output and velocity. This paper brings together criticisms of the $\mathrm{P}^{*}$ model together in an attempt to address the major concerns with an improvement upon the existing model. To this end, two variants of the classic $\mathrm{P}^{*}$ approach are tested. The first approach departs from the traditional approach of using potential GDP as the measure of equilibrium velocity and instead models equilibrium GDP with a constant and a trend, thus redefining the output gap. Equilibrium velocity is also modeled in this way, and the new output and velocity gaps are used to redefine P*. The second approach uses a Hodrick-Prescott filter to extract the mean of velocity and of output, and uses this smoothing mechanism to construct new velocity and output gaps. A horse race is then run between the original $\mathrm{P} *$ model, the two variant $\mathrm{P} *$ models, and three other models - an atheoretic naïve AR process and an ARMA process as well as a standard output gap type model (the Phillips curve approach). Inflation is forecasted in both levels and differences. The Hodrick-Prescott price gap has twice the explanatory power of the original price gap suggesting that it better captures the effects of money on inflation. Furthermore, the results show that the $\mathrm{P}^{*}$ approach modeled using a Hodrick Prescott filter marginally out-performs all the other models of inflation in terms of forecast accuracy, suggesting that it may be more useful for inflation-targeting purposes. Overall the results indicate that models based on past information cannot outperform the more sophisticated $\mathrm{P} *$-type models.
}

JEL Classification: E30, E31, E37, E52

Policy-makers must always keep their eye on macroeconomic variables for the purposes of designing and sequencing policy measures. Economic studies have thus spent a fair amount of time understanding the forces behind changes in the macro-economy, and forecasting macroeconomic variables such as output, employment and inflation. A section of the forecasting literature has dealt with understanding the behaviour of and predicting inflation.

Lillian Kamal, Department of Economics, West Virginia University, P.O. Box 6025, Morgantown, WV 26506.E-mail: ltkamal@mail.wvu.edu 
Accurate forecasting is important when it comes to inflation targeting. It has been suggested that since inflation responds to monetary policy with a lag of about one-two years (Bernanke and Woodford, 1997), monetary authorities would be better off targeting forecasts of inflation rather than the inflation rate itself. If this is an important strategy, then it is all the more important to accurately forecast inflation.

Past papers have emphasized the role of Phillips-curve type models (output gap models) in predicting inflation. In general, Phillips curve type models argue that inflation can be explained by lags of inflation and information contained in an output gap (reflecting the gap between current unemployment and the natural rate of unemployment). When the output gap is positive, inflation accelerates and the central monetary authority's usual response is to increase the interest rate (Razzak, 2002). Higher interest rates serve to slow the economy down, and output returns to the full employment level, this eliminating the output gap and reducing inflation.

Output gap models hinge on estimating the output gap correctly as the measure of full employment is always subject to discussion. There is always concern that incorrectly estimating the output gap would lead to unnecessary tightening and loosening of monetary policy (Razzak, 2002). This viewpoint is also shared by Orphanides (1998), who observes that "if policy-makers mistakenly adopt policies that are optimal under the presumption that their understanding of the state of the economy is accurate when, in fact, such accuracy is lacking, they inadvertently induce instability in both inflation and economic activity".

A portion of the inflation forecasting literature has concentrated on the link between money and prices. This paper focuses on one such link - the $\mathrm{P}^{*}$ approach. The $\mathrm{P}^{*}$ relationship relies on two fundamentals: the quantity theory of money and the lagged adjustment of prices. $\mathrm{P}^{*}$ is basically defined as that equilibrium price level that is consistent with current money supply and equilibrium in the goods and financial markets.

The $\mathrm{P}^{*}$ model was developed by Hallman, Porter and Small (1991) - henceforth referred to in this paper as HPS. The model arose out of an attempt to find the link between M2 and prices in the long run and also to solve the problem of which monetary aggregate to target to design effective monetary policy. The unique quality of this model is its emphasis on deviations of money velocity from "equilibrium" values as important in the determination of the level of prices.

The $\mathrm{P}^{*}$ approach is derived from the quantity theory of money. The basic idea is that there is an optimal price level $\left(\mathrm{P}^{*}\right)$ that is derived from the equilibrium values of velocity $\left(\mathrm{V}^{*}\right)$ and output $\left(\mathrm{Y}^{*}\right)$ in the economy. The $\mathrm{P}^{*}$ model assumes that output in the economy follows a smooth deterministic trend. The measure of equilibrium output $\mathrm{Y}^{*}$, is assumed not to be affected by monetary policy. Money is therefore neutral in the long run. The original $\mathrm{P}^{*}$ model also assumes that $\mathrm{V}^{*}$ is constant. To this end $\mathrm{V}^{*}$ is taken to be the mean or average value of velocity over a sample while the equilibrium measure of output growth in the economy is the potential GDP measure. Based on $\mathrm{V}^{*}$ and $\mathrm{Y}^{*}$, and actual money growth an equilibrium price level $\mathrm{P}^{*}$ is developed (as explained in section 2). $\mathrm{V}^{*}$ and $\mathrm{Y}^{*}$ are expected to return to their equilibrium values over time and this in turn drives $\mathrm{P}$ back to $\mathrm{P}^{*}$. Ultimately the main difference between the $\mathrm{P}^{*}$-type models and other inflation models such as the output gap models is the introduction of the velocity gap.

Policy recommendations then depend on the relationship of $\mathrm{P}^{*}$ to the actual price level. Needless to say the direction and magnitude of the difference between $\mathrm{P}$ and $\mathrm{P}^{*}$ is very important for policy formulation. The usefulness of the $\mathrm{P}^{*}$ model is only highlighted if it provides information that is not provided by other inflation models (Christiano, 1990).

The remainder of this paper is organized as follows: section 2 presents the theoretical formulation for the traditional $\mathrm{P}^{*}$ model, discusses further studies on the $\mathrm{P}^{*}$ model and considers some criticisms of the traditional $\mathrm{P}^{*}$ model. This section also introduces other models that are tested against the HPS approach, and discusses adjustments to the classic model. Overall the paper tests four other models - these are a benchmark ARMA process, a simple Phillips-curve 
model, and two re-defined $\mathrm{P}^{*}$-type models. Section 3 presents data and methodology. Section 4 discusses in-sample results for all the models, and also presents the out-of-sample forecasting performance of each of the above models. Section 5 presents robustness results and section 6 concludes.

\section{Theory}

\section{I. The P* Model According to HPS}

As mentioned, the basis of the $\mathrm{P}^{*}$ model lies in the quantity theory of money and the equation of exchange. The equation of exchange forms the root of the model:

$$
\mathrm{MV}=\mathrm{PY}
$$

Where $\mathrm{M}=\mathrm{M} 2$ (broad money stock); $\mathrm{V}=$ Velocity; $\mathrm{P}=$ GDP deflator, and $\mathrm{Y}=$ output in the economy at constant prices. The second step involves solving for the price level in the aggregate economy:

$$
\mathrm{P}=\mathrm{M}(\mathrm{V} / \mathrm{Y})
$$

Thereafter two key assumptions are made. Velocity and output are assumed to be mean reverting over time (that is they display cyclical behaviour). Output is assumed to revert to a measure of potential output over time. Potential output theoretically refers to the full employment level of national real output. The equilibrium values for velocity (for velocity this is taken to be the sample-mean) and output are entered into the equation of exchange and the equilibrium price level is solved for, resulting in equation (3) below.

Assumptions: $V$ and $Y$ will return to the equilibrium values $V^{*}$, and $Y^{*}$ over time.

$$
\mathrm{P}^{*}=\mathrm{M}\left(\mathrm{V}^{*} / \mathrm{Y}^{*}\right)
$$

$\mathrm{P}^{*}$ is the level of prices that is proportional to the money stock per unit of potential output. The next step involves taking natural logs of equations (2) and (3) - this gives us equations 2 ' and 3' below.

$$
\begin{aligned}
& \ln \mathrm{P}=\ln \mathrm{M}+\ln \mathrm{V}-\ln \mathrm{Y} \\
& \ln \mathrm{P}^{*}=\ln \mathrm{M}+\ln \mathrm{V}^{*}-\ln \mathrm{Y}^{*}
\end{aligned}
$$

Equation 4 below then solves explicitly for the price gap (done by subtracting equation 3 ' from 2').

$$
\left(\ln \mathrm{P}-\ln \mathrm{P}^{*}\right)=\left(\ln \mathrm{V}-\ln \mathrm{V}^{*}\right)+\left(\ln \mathrm{Y}^{*}-\ln \mathrm{Y}\right)
$$

To conserve on notation, equation (4) above is reduced to the form below:

$$
\left(\mathrm{p}-\mathrm{p}^{*}\right)=\left(\mathrm{v}-\mathrm{v}^{*}\right)+\left(\mathrm{y}^{*}-\mathrm{y}\right)
$$

Equation 4' carries an important implication - the only way that $\mathrm{P}$ can differ from $\mathrm{P}^{*}$ is if $\mathrm{V}$ differs from $\mathrm{V}^{*}$ or if $\mathrm{Y}$ differs from $\mathrm{Y}^{*}$. Equation (4') thus highlights the fact that the deviations 
of price from its equilibrium value can be measured by the summation of a velocity gap and an output gap. At this point, HPS refer to the work of Mussa (1981) and McCallum (1980) who present inflation adjustment equations that model current inflation as dependent on forwardlooking information. Mussa's equation is equation (5) below:

$$
\pi_{t}=\alpha\left[p_{t}-\bar{p}_{t}\right]+\bar{\pi}_{t} ; \alpha>0
$$

Where $\bar{\pi}_{t}$ is an estimate of the expected growth in the equilibrium price level $\bar{p}$. In Mussa's model, the equilibrium price level is the price level when the money market is in equilibrium, although the variables that affect money demand are not expected to be in equilibrium. McCallum's equation is equation (6) below; again, inflation responds to the gap between actual and equilibrium price levels. McCallum's equilibrium price level is also forward looking - it represents the equilibrium price level that would occur if the economy were performing at capacity, given current aggregate demand. The main difference between Mussa's and McCallum's equilibrium price levels and HPS $\mathrm{p}^{*}$ is that the former do not incorporate deviations in velocity.

$$
\pi_{t}=\alpha\left[p_{t-1}-\tilde{p}_{t-1}\right]+\mathrm{E}_{t-1}\left[\tilde{p}_{t}-\tilde{p}_{t-1}\right] ; \alpha>0
$$

HPS incorporate all forward-looking information into $\mathrm{p}^{*}$ itself, and include only backward looking information instead of the second term used by Mussa and McCallum. They propose a simple ad hoc formulation that uses the previous period's inflation measure as the best estimation of lagged information over their sample period (1955-1988).

HPS then present their versions of equations 5 and 6 above in the form of equation 5 , below.

$$
\begin{aligned}
& \pi_{t}=\alpha\left[p_{t-1}-p^{*}{ }_{t-1}\right]+\pi_{t-1} ; \alpha>0 \\
& \Delta \pi_{t}=\alpha\left[p_{t-1}-p^{*}{ }_{t-1}\right] ; \alpha>0
\end{aligned}
$$

Equation 6' simply has the last lag of inflation moved to the left hand side of equation 5', and thus shows that accelerations of inflation are also related to the price gap. HPS include the possibility that further lags of inflation can be included - they extend the model to include four lags of the accelerations in inflation. In generalized form then, HPS then present the P* model as a function of a price gap and the sum of lagged changes in inflation:

$$
\Delta \pi_{t}=\alpha\left(p-p^{*}\right)_{t-1}+\beta_{1} \Delta \pi_{t-1}+\beta_{2} \Delta \pi_{t-2}+\beta_{3} \Delta \pi_{t-3}+\beta_{4} \Delta \pi_{t-4}
$$

Overall, it is vital to note that the validity of the money-supply driven models of the price level depend on two key assumptions: that there is an identifiable trend in the velocity of money and that money is in fact, neutral in the long run. Potential output is therefore not affected by money supply changes. 


\section{II) Further Work on the P* Model}

The $\mathrm{P}^{*}$ approach is based on a long-run view of the equation of exchange. HPS have shown that the model has proven explanatory power over the 2-3 year forecasting horizon. However, it has received a fair amount of criticism over the years. The basic model assumes that velocity is mean reverting, and thus returns to its equilibrium value over time. Pecchenino and Rasche (1990) have discussed the idea that neither velocity nor output is in fact, mean reverting. This criticism loses its significance, however, when one considers that velocity and output do not enter the $\mathrm{P}^{*}$ model directly - they do so in terms of gaps. Hoeller and Poret (1991) have shown that if a linear combination of two non-stationary gaps is stationary, then the non-stationary gaps can enter a regression as right hand side variables. For econometric stability then it need only be necessary for the price gaps to be stationary and not the individual component deviations of velocity and output from equilibrium values.

The basic $\mathrm{P}^{*}$ model forecasts inflation in accelerations of the inflation rate. Ebrill and Fries (1991) have suggested that it is more appropriate to predict inflation in levels rather than differences. They find that the equation specified in levels has a better fit. The original $\mathrm{P}^{*}$ model regresses changes in the inflation rate on current inflation - in effect a change in the inflation rate is a difference of a difference and can lead to serial correlation. This paper cannot confirm this finding. When a model in differences is run against a model in levels, there is no evidence of serial correlation (as evidenced by the Durbin-Watson statistic). ${ }^{1}$

A criticism of the model offered by Christiano (1989) is that the introduction of Super NOW (Negotiable Order of Withdrawal) accounts has led to a permanent downward shift in M2 velocity (with NOW-type accounts, a minimum balance is required to earn a higher interest rate this restricts expenditure from an account of this type). Hallman and Anderson (1993) tested for this hypothesis, however, and were able to reject the hypothesis of a shift in M2 velocity. Related to this concern, is Orphanides and Porter's (2000) criticism of the modeling of equilibrium velocity as a constant. A constant $\mathrm{V}^{*}$ does not allow for shifts or changes, and may cause an unnecessary increase in the magnitude of the velocity gap.

A key issue that then arises with the $\mathrm{P}^{*}$ models is the identification of the $\mathrm{Y}^{*}$ process, and the $\mathrm{V}^{*}$ process. Past studies have used the notion of deterministic trends to identify these processes. Christiano (1989) used a linear time trend to calculate equilibrium output. Hoeller and Poret (1991) test two alternative specifications of this process (in a group of OECD countries) - one of these is a linear process, and the other utilizes a filter method that extracts the low frequency component of real GDP. However, it has been suggested by time series analysis that real GDP may follow a stochastic rather than deterministic trend. The identification of stochastic trends in a process can be done using two approaches. The first approach would be the use of a structural approach. Ebrill and Fries (1990) and Pecchenino and Rasche (1990) use measures based on a combination of the natural rate of unemployment and Okun's Law to identify potential output. HPS (1990) use the fitted values of a cointegration approach - they regress velocity on a measures of the labour force employed in agriculture. They use this labour variable as a proxy for the industrialization and monetization of the US (Hoeller and Poret, 1991). However, the use of structural approaches may yield non-stationary price gaps, which would then violate the assumptions of the $\mathrm{P}^{*}$ model.

The second approach to identity potential output and equilibrium velocity is the use of filters, which serve to extract the stochastic trends from the series. Bomhoff (1990) used a Kalman filter to identify velocity in OECD countries. Hoeller and Poret (1991) use of a Hodrick-Prescott filter

\footnotetext{
${ }^{1}$ The DW statistic is 1.98 for a model in differences and 1.97 for a model in levels. The finding of no evidence of any serial correlation is subject to debate as it has been suggested that the DW statistic loses its significance somewhat when lagged dependent variables are included on the RHS.
} 
to extract the equilibrium value of output. The main advantage that the Hodrick-Prescott filter has over the Kalman filter is its computational ease. The smoothing parameter is chosen based on split of the series into a "transitory" component and a "permanent" component. A very large smoothing factor would indicate that most of the series is an almost constant trend. This indicates that most of the shocks are transitory. On the other hand, a very small smoothing factor would indicate that most of the shocks are, in fact, permanent, that is they are reflective of changes in trend. (Hoeller and Poret, 1991.) The exact choice of the smoothing factor then becomes critical.

As mentioned, Orphanides and Porter (2000) experimented with using a time trend in identifying equilibrium velocity and they find that while significant, a time trend has a very small positive effect on equilibrium velocity. Including a time trend alone cannot then explain the apparent upward shift in velocity over the last 15 years. They therefore include a dummy variable for a shift in velocity. Hoeller and Poret's filter technique then becomes more attractive because the complications of including a dummy for an unknown shift date in velocity are removed. The use of a filter allows the smooth extraction of equilibrium velocity that has already endogenized minor breaks in the data.

Tatom (1990) cites two flaws with the $\mathrm{P} *$ model - the assumptions of stationarity of M2 velocity and of the price gap, and the lack of an MA error process in any autoregressive specification of current inflation. Tatom also suggests that the $\mathrm{P} *$ approach with $\mathrm{M} 2$ velocity may have specification errors and thus models a $\mathrm{P}^{*}$ model using M1 velocity. He finds that the M1 P* approach finds a significant relationship between M1 and prices. It is important to note, however, that the introduction of innovations such as Super-NOW accounts will have increased M1 velocity and thus will over-identify the velocity gap. M2 velocity on the other hand will not be affected by such innovations.

Hoeller and Poret (1991) have found that the $\mathrm{P}^{*}$ model works better in larger rather than smaller countries. Kool and Tatom (1994) test to see whether differences in the prevailing exchange rate systems are an explanation for this dichotomy. The original $\mathrm{P}^{*}$ approach models prices as a function of the money supply. Under fixed exchange rate systems, however, the price level is determined abroad and money supply is exogenously determined. Money supply under fixed exchange rate schemes then becomes demand-determined. Kool and Tatom therefore develop a generalized $\mathrm{P}^{*}$ approach that accounts for an international effect by including crosscountry gaps. They find that the $\mathrm{P}^{*}$ model holds for both flexible and fixed-exchange rate system countries although in countries with fixed exchange rate schemes, the equilibrium price level is determined by foreign monetary policy.

Fleissig and Fisher (1995) make the assumption that the $\mathrm{P}^{*}$ model is in fact, correct, and thereafter work on searching for the best monetary aggregate that fits the model. They disagree with the use of simple sum aggregates. Simple sum aggregates do not account for the imperfect substitutability between the components of the aggregates. For example, with reference to M2, cash and money market mutual funds are imperfect substitutes. Fleissig and Fisher use divisia aggregates that better account for the different rates of return on each of the components of the aggregates. They find that the use of divisia-type aggregates improves the explanatory power of the $\mathrm{P} *$ model.

As is evident from the above discussion, a significant amount of work has been done with $\mathrm{P}^{*}$ type models. While some studies have found support for the models, an equal number of studies have suggested modifications that are expected to increase their explanatory power. The following section adopts some of the modifications in an attempt to improve upon the original HPS model. 


\section{III) Adjustments to the Model}

This section attempts to address some of the concerns raised in the literature about the formulation of the original $\mathrm{P}^{*}$ model. One of the first criticisms that is addressed is the HPS use of a constant equilibrium value. Following HPS, assumptions are made that velocity and output are mean reverting. However, the equilibrium values of velocity and output are modeled as timevariant. The simplest model of such a process would reflect a constant and a time trend. These processes are therefore modeled as follows:

$$
\begin{aligned}
& v_{t}^{*}=\alpha+b t \\
& y^{*}{ }_{t}=\phi+\gamma t
\end{aligned}
$$

where $\mathrm{t}$ is a time trend. Equations 8' and 8', are then nested into the velocity and output gaps.

Including a linear time trend ${ }^{2}$ in the equation for equilibrium velocity allows $\mathrm{v}^{*}$ to vary over time - this then allows equilibrium velocity to change over time. From the above process for equilibrium velocity, the velocity gap; ( $\left.\mathrm{v}-\mathrm{v}^{*}\right)$, can then be derived. Equilibrium output is also modeled in this way to allow for a constant growth rate. The output gap; $\left(\mathrm{y}^{*}-\mathrm{y}\right)$, can then be derived as being positive during downturns in the economy (contractions in the business cycle), and negative during growth periods in economic activity (expansions).

HPS have differenced inflation rates - the acceleration of past inflation - as RHS variables to deal with stationarity issues. A drawback of differencing the data as HPS have done is that there is a loss of long-run information - "differencing eliminates all info on the long run properties of the model" 3 . One solution is to run the model in a levels ${ }^{4}$ form, while another solution is to run a vector error correction model. This paper runs the equations in both levels and differenced forms. Constant terms are also included in both the levels and differenced equation forms.

$$
\begin{aligned}
& \pi_{t}=\delta+\beta_{1}\left(p-p^{*}\right)_{t-1}+\beta_{2} \pi_{t-1}+\beta_{3} \pi_{t-2}+\beta_{4} \pi_{t-3}+\beta_{5} \pi_{t-4}+\mu_{t} \\
& \text { where }\left(p-p^{*}\right)_{t-1}=\left(v-v^{*}\right)_{t-1}+\left(y^{*}-y\right)_{t-1}
\end{aligned}
$$

\section{IV) Models Based on Past Information}

The basic approach to forecasting a series would be to use only past information. Studies have compared the $\mathrm{P}^{*}$ type models with AR-type models. Hoeller and Poret (1991) compare the $\mathrm{P}^{*}$ approach with a standard second order autoregressive model. In this paper, the benchmark models are two-fold - an AR(4) approach and a simple ARMA $(4,4)^{5}$ approach - adopting the

\footnotetext{
${ }^{2}$ Non-linear time trends are tested and found to be insignificant.

${ }^{3}$ See Maddala, Page 262.

${ }^{4}$ As mentioned earlier, Ebrill and Fries have shown that modeling inflation in levels is the more appropriate specification.

${ }^{5}$ This model is chosen based on both the minimum AIC and SBC criteria.
} 
MA terms is necessary to remove serial correlation. By modeling inflation using an ARMA process, Tatom's (1990) concern about the lack of MA terms is addressed. Using this approach, the current inflation rate is explained using four lags of inflation and four MA terms. Equation 9 and 10 below presents the models based on past information alone.

$$
\begin{aligned}
& \pi_{t}=\delta+\alpha_{1} \pi_{t-1}+\alpha_{2} \pi_{t-2}+\alpha_{3} \pi_{t-3}+\alpha_{4} \pi_{t-4}+\mu_{t} \\
& \pi_{t}=\delta+\alpha_{1} \pi_{t-1}+\alpha_{2} \pi_{t-2}+\alpha_{3} \pi_{t-3}+\alpha_{4} \pi_{t-4}+\gamma_{1} \varepsilon_{t-1}+\gamma_{2} \varepsilon_{t-2}+\gamma_{3} \varepsilon_{t-3}+\gamma_{4} \varepsilon_{t-4}
\end{aligned}
$$

\section{Data and Methodology}

\section{I) Methodology}

The sample is split into an in-sample period from 1959:1-1989:4 and then an out-of-sample period (for forecasting purposes) from 1990:1 2003:4. The data is from the Federal Reserve Bank of St. Louis (FRED2).

Based on the discussion in section 2, the following six models are run:

1. A benchmark AR(4) model;

2. The benchmark ARMA $(4,4)$ model;

3. HPS model with a constant equilibrium velocity (the traditional $\mathrm{P}^{*}$ ); (This model is henceforth referred to as P*-HPS)

4. A redefined $\mathrm{P}^{*}$-type model where the equilibrium values of output and velocity are each modeled on a constant and a time trend; (This model is henceforth referred to as $\mathrm{P}^{*}$ BASIC)

5. A P* type model where equilibrium velocity and output are filtered out using a HodrickPrescott filter. (This model is henceforth referred to as $\mathrm{P}^{*}$-HOD)

6. A standard Phillips-curve type model with an output gap.

A standard Phillips-curve type model based on Lucas is used in this paper. This is the most basic form of the Phillips curve type model, where the output gap is measured as a deviation of output from the potential output level. The idea of potential output was first introduced by Okun (1965) - it basically refers to that level of output that exists when the economy is producing at the full employment level. In general, the Phillips curve represents the relationship between the output gap (unemployment gap) and inflation (wage inflation). When the output gap is positive, inflation accelerates, and monetary authorities respond by increasing the interest rate if they wish to reduce inflation. A higher interest rate reduces demand for investment and consumption and thus reduces inflation.

Following HPS, inflation is defined as: $\pi_{t}=400 / \mathrm{k}^{*} \log (\mathrm{Pt} / \mathrm{Pt}-\mathrm{k})$ where $\mathrm{k}$ is the quarter and $\mathrm{P}$ is the price level (the GDP deflator). The six models are run over the in-sample period and 
then a rolling forecast method is adopted over the out-of-sample period 1990:1 to 2003:4, whereby the in-sample data set is increased by a quarter each time. Initially the forecasts are performed for the $\mathrm{k}=1$ horizon and $\mathrm{k}=4$ horizons. For robustness purposes, in section 6 , the forecasting horizon is expanded to 12 quarters ahead.

\section{II) Data and Statistics}

Reflecting the concern that the price gaps may not be stationary over time, standard Augmented Dickey-Fuller tests are performed. As mentioned a linear combination of two nonstationary variables may be stationary. Table 1 displays the results of unit root tests for the different price gaps over the sample period. The augmented Dickey-Fuller tests show that the basic price gap is clearly non-stationary, while the HPS price gap is stationary between the 5\% and $10 \%$ significance levels. The HOD gap is stationary at the $1 \%$ significance level. It is important to note that, as mentioned earlier, the velocity gaps and the output gaps do not need to be stationary if the price gap (which is a linear combination of the velocity gap and the output gap) is stationary.

Table 1: Unit Root Tests on The Different Price Gaps

\begin{tabular}{|l|l|}
\hline Type of Price Gap & ADF test statistic \\
\hline$P-P^{*}$ (HPS) & -2.652987 \\
\hline$P-P^{*}$ (Basic) & -2.397577 \\
\hline$P-P^{*}$ (Hodrick-Prescott Filter) & -4.813505 \\
\hline & \\
\hline & ( Critical Values are -3.4861 at the $1 \%$ significance level and -2.5795 at the $10 \%$ significance level.
\end{tabular}

Johansen's cointegration test is then performed on the HPS price gap and the basic price gap. The HPS and BASIC velocity gaps and output gaps show evidence of cointegration ${ }^{6}$.

All three types of velocity and output gaps are tested for structural breaks. The methodology used follows the assumption that the break dates are unknown. The basic methodology is as follows: Chow tests are performed for each possible break date by quarter. The maximal $F$ statistic is then compared with critical values generated through bootstrap techniques ${ }^{7}$. This technique effectively endogenizes the break date. The F values are presented in the Appendix in Table A1.

6 The cointegrating relationships are ygapbasic -7.377177 vgapbasic +0.005430 , and ygaphps -3.890184 vgaphps -0.015666

${ }^{7}$ For a detailed discussion, see Christiano (1988). 


\section{Results}

Table One presents in-sample results from the model based on past information, the three $\mathrm{P}^{*}$ type models, and the simple Phillips-Curve type model. The dependent and independent inflation variables are all specified in terms of accelerations. The results above indicate that all price gaps tested are significant in explaining inflation. The HOD gap has twice the explanatory power of the HPS gap, and it is also the gap that is the most significant in explaining current changes in inflation. The overall regression with the Hodrick-Prescott filter has an adjusted Rsquared of 0.23 which is marginally better than the HPS approach. While the AR and ARMA approaches are appealing in their simplicity and their econometric sense, they have the lowest adjusted R-squared values. It is interesting to note that the output gap in the Phillips-curve type model has about the same explanatory power as the HPS price gap, indicating that the HPS price gap is not capturing much more information than a simple output gap. This suggests that the HPS gap is deficient in capturing the effect of changes in velocity on inflation; the result is more obvious when compared with the Hodrick-Prescott gap that has double the explanatory power.

Table 1: Dependent Variable - Acceleration of Inflation

\section{Sample period: 1959:1 1989:4}

\begin{tabular}{|c|c|c|c|c|c|c|}
\hline Model & $A R(4)$ & $\operatorname{Arma}(4,4)$ & HPS P* & $P *$ Basic & $P *-H P$ filter & Phillips \\
\hline$\delta$ & $\begin{array}{l}0.015651 \\
(0.138073)\end{array}$ & $\begin{array}{l}0.029025 \\
(0.138969)\end{array}$ & $\begin{array}{l}0.243659 \\
(1.964409)\end{array}$ & $\begin{array}{l}0.000858 \\
(0.007841)\end{array}$ & $\begin{array}{l}0.032649 \\
(0.306634)\end{array}$ & $\begin{array}{l}0.251681 \\
(1.941815)\end{array}$ \\
\hline$\left(p-p^{*}\right)_{t-1}$ & & & $\begin{array}{l}-14.11991 \\
(-3.687117) \\
\end{array}$ & $\begin{array}{l}-9.764301 \\
(-3.064566)\end{array}$ & $\begin{array}{l}-28.526630 \\
(-4.034140) \\
\end{array}$ & \\
\hline$(y *-y)_{t-1}$ & & & & & & $\begin{array}{l}-14.46439 \\
(-3.335855)\end{array}$ \\
\hline $\boldsymbol{\Pi}_{t-1}$ & $\begin{array}{l}-0.338084 \\
(-3.649262)\end{array}$ & $\begin{array}{l}-0.744503 \\
(-0.568910)\end{array}$ & $\begin{array}{l}-0.448039 \\
(-4.828072)\end{array}$ & $\begin{array}{l}-0.418739 \\
(-4.493912)\end{array}$ & $\begin{array}{l}-0.460596 \\
(-5.000793)\end{array}$ & $\begin{array}{l}-0.438612 \\
(-4.679568)\end{array}$ \\
\hline $\boldsymbol{\Pi}_{t-2}$ & $\begin{array}{l}-0.190784 \\
(-1.946159) \\
\end{array}$ & $\begin{array}{l}-0.369909 \\
(-0.344978) \\
\end{array}$ & $\begin{array}{l}-0.321998 \\
(-3.234107) \\
\end{array}$ & $\begin{array}{l}-0.286790 \\
(-2.878390)\end{array}$ & $\begin{array}{l}-0.337671 \\
(-3.412464) \\
\end{array}$ & $\begin{array}{l}-0.317025 \\
(-3.131078) \\
\end{array}$ \\
\hline $\boldsymbol{\Pi}_{t-3}$ & $\begin{array}{l}-0.065791 \\
(-0.671324)\end{array}$ & $\begin{array}{l}-0.318862 \\
(-0.420008)\end{array}$ & $\begin{array}{l}-0.194561 \\
(-1.959280)\end{array}$ & $\begin{array}{l}-0.158622 \\
(-1.597602)\end{array}$ & $\begin{array}{l}-0.213768 \\
(-2.158692)\end{array}$ & $\begin{array}{l}-0.194042 \\
(-1.912645)\end{array}$ \\
\hline $\boldsymbol{\Pi}_{t-4}$ & $\begin{array}{l}0.176816 \\
(1.902570)\end{array}$ & $\begin{array}{l}-0.024270 \\
(-0.036852)\end{array}$ & $\begin{array}{l}0.080643 \\
(0.877224)\end{array}$ & $\begin{array}{l}0.107666 \\
(1.164454)\end{array}$ & $\begin{array}{l}0.067837 \\
(0.742900)\end{array}$ & $\begin{array}{l}0.079023 \\
(0.843058)\end{array}$ \\
\hline $\mathcal{E}_{t-1}$ & & $\begin{array}{l}0.410236 \\
(0.314239)\end{array}$ & & & & \\
\hline $\mathcal{E}_{t-2}$ & & $\begin{array}{l}0.039694 \\
(0.056684)\end{array}$ & & & & \\
\hline $\mathcal{E}_{t-3}$ & & $\begin{array}{l}0.177702 \\
(0.474420)\end{array}$ & & & & \\
\hline $\mathcal{E}_{t-4}$ & & $\begin{array}{l}0.131580 \\
(0.305962)\end{array}$ & & & & \\
\hline $\begin{array}{l}\text { Adjusted } \\
R \text {-squared }\end{array}$ & 0.12 & 0.09 & 0.21 & 0.18 & 0.23 & 0.20 \\
\hline
\end{tabular}

t-statistics significant at the $5 \%$ level or less. 
Following Ebrill and Fries, the various models are also tested in terms of levels, where the current inflation rate is predicted as opposed to the changes in the current inflation rate. The dependent inflation specifications are in levels. These findings are presented in Table 3 below. The results are similar - the Hodrick-Prescott filter gap has more than double the explanatory power of the HPS gap, and the explanatory power of the HPS gap is approximately the same the simple output gap tested in the Phillips-curve type model. An interesting vindication of the Ebrill-Fries levels approach is the jump in adjusted R-squared values when the models are run in levels terms.

Table 2: Dependent variable: level of inflation

\section{Sample period: 1959:1 1989:4}

\begin{tabular}{|c|c|c|c|c|c|c|}
\hline \multicolumn{7}{|c|}{ Dependent variable: Inflation Rate: Independent variables are levels of inflation rate } \\
\hline Model & AR(4) & $\operatorname{Arma}(4,4)$ & HPS P* & Re-defined $P^{*}$ & $P *$ - HP filter & Phillips \\
\hline$\delta$ & $\begin{array}{c}0.369540 \\
(1.598738)\end{array}$ & $\begin{array}{c}0.652576 \\
(1.463616)\end{array}$ & $\begin{array}{c}0.308548 \\
(1.403088)\end{array}$ & $\begin{array}{c}0.522945 \\
(2.370464)^{*}\end{array}$ & $\begin{array}{c}0.322320 \\
(1.499609)\end{array}$ & $\begin{array}{c}0.404675 \\
(1.829496)\end{array}$ \\
\hline$\left(\mathbf{p}-\mathbf{p}^{*}\right)_{t-1}$ & & & $\begin{array}{c}-14.68059 \\
(-3.696414)^{*}\end{array}$ & $\begin{array}{c}-12.17137 \\
(-4.004955) *\end{array}$ & $\begin{array}{c}-29.25946 \\
(-4.378905) *\end{array}$ & \\
\hline$\left(\mathbf{y}^{*}-\mathbf{y}\right)_{t-1}$ & & & & & & $\begin{array}{r}-14.70485 \\
(-3.428551)^{*}\end{array}$ \\
\hline$\left(\mathbf{v}-\mathbf{v}^{*}\right)_{t-1}$ & & & & & & \\
\hline$\pi_{t-1}$ & $\begin{array}{c}0.611103 \\
(6.557607)^{*}\end{array}$ & $\begin{array}{c}0.324534 \\
(0.833800)\end{array}$ & $\begin{array}{c}0.533920 \\
(5.877521)^{*}\end{array}$ & $\begin{array}{c}0.509574 \\
(5.588311)^{*}\end{array}$ & $\begin{array}{c}0.503581 \\
(5.597726) *\end{array}$ & $\begin{array}{c}0.537997 \\
(\mathbf{5 . 8 7 3 4 0 4}) *\end{array}$ \\
\hline $\boldsymbol{\pi}_{t-2}$ & $\begin{array}{c}0.114753 \\
(1.051446)\end{array}$ & $\begin{array}{c}0.341659 \\
(0.924570)\end{array}$ & $\begin{array}{c}0.115806 \\
(1.118471)\end{array}$ & $\begin{array}{c}0.099213 \\
(0.966477)\end{array}$ & $\begin{array}{c}0.102218 \\
(1.008093)\end{array}$ & $\begin{array}{c}0.107222 \\
(1.027512)\end{array}$ \\
\hline $\boldsymbol{\pi}_{t-3}$ & $\begin{array}{c}0.087263 \\
(0.799934)\end{array}$ & $\begin{array}{c}-0.030543 \\
(-0.081424)\end{array}$ & $\begin{array}{c}0.115219 \\
(1.110361)\end{array}$ & $\begin{array}{c}0.096102 \\
(0.937060)\end{array}$ & $\begin{array}{c}0.103300 \\
(1.018973)\end{array}$ & $\begin{array}{c}0.106682 \\
(1.021536)\end{array}$ \\
\hline$\pi_{t-4}$ & $\begin{array}{c}0.108845 \\
(1.176404)\end{array}$ & $\begin{array}{c}0.222092 \\
(0.645547) \\
\end{array}$ & $\begin{array}{c}0.223382 \\
(2.399753)^{*}\end{array}$ & $\begin{array}{c}0.179022 \\
(2.017999)\end{array}$ & $\begin{array}{c}0.225899 \\
(2.510295) *\end{array}$ & $\begin{array}{c}0.215277 \\
(2.296656) *\end{array}$ \\
\hline $\mathcal{E}_{t-1}$ & & $\begin{array}{c}0.305295 \\
(0.789486)\end{array}$ & & & & \\
\hline $\mathcal{E}_{t-2}$ & & $\begin{array}{c}-0.023549 \\
(-0.061161)\end{array}$ & & & & \\
\hline $\mathcal{E}_{t-3}$ & & $\begin{array}{c}0.186397 \\
(0.601499) \\
\end{array}$ & & & & \\
\hline $\mathcal{E}_{t-4}$ & & $\begin{array}{c}0.166112 \\
(0.986327)\end{array}$ & & & & \\
\hline $\begin{array}{c}\text { Adjusted } \\
\text { R-squared }\end{array}$ & 0.78 & 0.79 & 0.80 & 0.80 & 0.81 & 0.79 \\
\hline
\end{tabular}

t-statistics significant at $5 \%$ level or less.

As has been shown earlier, the HOD price gap has greater explanatory power than the HPS price gap, and the BASIC price gap. An interesting exercise is to test for the difference in explanatory power of the various velocity and output gaps for the different models. The purpose of this exercise is to identify whether it is indeed a money shock or a supply shock that has the greater impact on future inflation. The equations are presented below as equations 10-12. Table 3 below separates the price gaps into velocity gaps and output gaps for all three price gap models.

The results are startling. The lagged velocity gaps using both the classic HPS approach and the BASIC approach are insignificant in explaining current inflation. The implication is 
unmistakable - both these gaps are inadequate in capturing the link between money and inflation. The HOD velocity gap on the other hand is highly significant in explaining current inflation. The coefficient on the lagged velocity gap is as expected - it is negative indicating that if the velocity gap were positive for example, inflation would decelerate as velocity reverted back to its equilibrium value. The lagged output gaps in all the three models are similar in terms of magnitude and significance, although the HOD output gap is most significant. Under all three $\mathrm{P}^{*}$ approaches, the output gaps are significant in explaining inflation. This would indicate the dominance of a supply-side effect (the output gap is significant). A failure to compare the classic $\mathrm{P}^{*}$ approach with other variations of the price gap models would result in a conclusion base don the dominance of supply gaps in explaining inflation, and a lesser role of money. The implication is unmistakable - a greater role for money in explaining inflation exists only if the gap is measured correctly.

$$
\begin{aligned}
& \pi_{t}=\boldsymbol{\delta}+\beta_{1}\left(v-v^{*}\right)_{t-1} H P S+\beta_{2}\left(y^{*-y}\right)_{t-1} H P S+\delta_{1} \pi_{t-1}+\delta_{2} \pi_{t-2}+\delta_{3} \pi_{t-3}+\delta_{4} \pi_{t-4}+\mu_{t} \\
& \pi_{t}=\boldsymbol{\delta}+\beta_{1}\left(v-v^{*}\right)_{t-1} B A S I C+\beta_{2}\left(y^{*-y)}\right)_{t-1} B A S I C+\delta_{1} \pi_{t-1}+\delta_{2} \pi_{t-2}+\delta_{3} \pi_{t-3}+\delta_{4} \pi_{t-4}+\mu_{t} \\
& \pi_{t}=\boldsymbol{\delta}+\beta_{1}\left(v-v^{*}\right)_{t-1} H O D+\beta_{2}\left(y^{*}-y\right)_{t-1} H O D+\delta_{1} \pi_{t-1}+\delta_{2} \pi_{t-2}+\delta_{3} \pi_{t-3}+\delta_{4} \pi_{t-4}+\mu_{t}
\end{aligned}
$$

\begin{tabular}{|c|c|c|c|}
\hline \multicolumn{4}{|c|}{ Dependent variable: Inflation rate } \\
\hline Model & HPS P* & Re-defined P* & P* - HP filter \\
\hline$\delta$ & $\begin{array}{l}0.2132 \\
(0.8407)\end{array}$ & $\begin{array}{c}0.4596 \\
(1.8228)\end{array}$ & $\begin{array}{l}0.14038 \\
(0.6421)\end{array}$ \\
\hline$\left(\mathrm{y}^{*}-\mathrm{y}\right)_{t-1}$ & $\begin{array}{l}-13.3277 \\
(-3.0567)^{*}\end{array}$ & $\begin{array}{l}-11.3477 \\
(-3.3090)^{*}\end{array}$ & $\begin{array}{l}-30.6374 \\
(-4.7079) *\end{array}$ \\
\hline$\left(\mathrm{V}-\mathrm{V}^{*}\right)_{t-1}$ & $\begin{array}{l}-28.7542 \\
(-1.5159)\end{array}$ & $\begin{array}{l}-23.8274 \\
(-1.0624)\end{array}$ & $\begin{array}{l}-116.6621 \\
(-3.6541)^{*}\end{array}$ \\
\hline$\Pi_{t-1}$ & $\begin{array}{l}0.5366 \\
(5.8917)^{*}\end{array}$ & $\begin{array}{l}0.5133 \\
(5.5943) *\end{array}$ & $\begin{array}{l}0.4903 \\
(5.6034) *\end{array}$ \\
\hline$\Pi_{t-2}$ & $\begin{array}{l}0.1247 \\
(1.1946)\end{array}$ & $\begin{array}{l}0.1066 \\
(1.0255)\end{array}$ & $\begin{array}{l}0.1368 \\
(1.3780)\end{array}$ \\
\hline$\Pi_{t-3}$ & $\begin{array}{l}0.1216 \\
(1.1662)\end{array}$ & $\begin{array}{l}0.1012 \\
(0.9792)\end{array}$ & $\begin{array}{l}0.1281 \\
(1.2963)\end{array}$ \\
\hline$\Pi_{t-4}$ & $\begin{array}{l}0.2215 \\
(2.3745)^{*}\end{array}$ & $\begin{array}{l}0.1767 \\
(1.9835) \\
\end{array}$ & $\begin{array}{l}0.2215 \\
(2.5345) *\end{array}$ \\
\hline $\begin{array}{l}\text { Adjusted R- } \\
\text { squared }\end{array}$ & 0.80 & 0.80 & 0.82 \\
\hline
\end{tabular}

Table 3: Dependent variable: levels of inflation

To evaluate the best forecast in any horizon, previous studies such as those by Christiano (1989), HPS (1991, and Fisher (1995) are followed in using the root mean square error (RMSE) measure. Table 4 presents the RMSE values for all five models over three different forecast horizons. To reiterate, the forecasts are generated using a rolling-regression forecast method where the in-sample regression period is extended one quarter at a time. 
Table Four: RMSE for forecasts over different horizons

\begin{tabular}{|c|c|c|c|}
\hline \multicolumn{4}{|c|}{ RMSE values for forecasts of the various models } \\
\hline & One quarter ahead & Four quarters ahead & Twelve quarters ahead \\
\hline $\begin{array}{c}\text { AR(4) } \\
(C H A N G E S A P P R O A C H)\end{array}$ & 0.750162 & 0.735665 & 0.697726 \\
\hline $\begin{array}{c}\mathrm{AR}(4) \\
\text { LEVELS APPROACH }\end{array}$ & 0.792505 & 0.777376 & 0.728175 \\
\hline $\begin{array}{c}\text { ARMA }(4,4) \\
\text { CHANGES APPROACH }\end{array}$ & 0.759487 & 0.743610 & 0.724363 \\
\hline $\begin{array}{c}\text { ARMA }(4,4) \\
(\mathrm{LEVELS} \mathrm{APPROACH})\end{array}$ & 0.787097 & 0.776273 & 0.754799 \\
\hline $\begin{array}{c}\text { PHILLIPS CURVE } \\
\text { (CHANGES APPROACH) }\end{array}$ & 0.728281 & 0.723850 & 0.716098 \\
\hline $\begin{array}{c}\text { PHILLIPS CURVE } \\
\text { (LEVELS APPROACH) }\end{array}$ & 0.757872 & 0.753415 & 0.743973 \\
\hline $\begin{array}{c}\text { PSTAR-HPS } \\
(C H A N G E S \text { APPROACH) }\end{array}$ & 0.709787 & 0.701652 & 0.698050 \\
\hline $\begin{array}{c}\text { PSTAR-HPS } \\
(\text { LEVELS APPROACH) }\end{array}$ & 0.704194 & 0.693700 & 0.684242 \\
\hline $\begin{array}{c}\text { PSTAR-HOD } \\
(C H A N G E S \text { APPROACH) }\end{array}$ & 0.665462 & 0.659512 & 0.639282 \\
\hline $\begin{array}{c}\text { PSTAR-HOD } \\
\text { (LEVELS APPROACH) }\end{array}$ & 0.688707 & 0.683009 & 0.657129 \\
\hline $\begin{array}{c}\text { PSTAR-BASIC } \\
(C H A N G E S \text { APPROACH }\end{array}$ & 0.954041 & 0.952337 & 0.987512 \\
\hline $\begin{array}{c}\text { PSTAR-BASIC } \\
(\text { LEVELS APPROACH) }\end{array}$ & 0.863352 & 0.857674 & 0.879028 \\
\hline
\end{tabular}


The different models are initially tested in terms of forecasting ability over the onequarter-ahead horizon, and then the forecasts are tested over the one-year-ahead (four-quarterahead) horizon. Forecasts are evaluated for all models formulated both in terms of accelerations of inflation and levels of inflation. Table four presents the RMSE measures for all the models over the $\mathrm{k}=1$ and $\mathrm{k}=4$ horizons. The model that performs the worst in terms of forecasts is $\mathrm{P} * \mathrm{BASIC}$ - this is not totally unexpected due to the simplistic nature of the equilibrium velocity and output processes. The Phillips curve forecasts mildly out-perform the autoregressive forecasts of inflation. The classic P*HPS approach and P*HOD are similar in terms of RMSE measures. However, the lowest-error predictions of forecasts are generated by P*HOD; this findings holds over both the shorter-term horizons and regardless of whether it is the changes of inflation or the levels of inflation that are being predicted. Table 4 also includes a robustness check for forecasting accuracy - the forecasting horizon is extended to the $\mathrm{k}=12$ horizon. Again, $\mathrm{P}^{*} \mathrm{HOD}$ out-performs the other models in terms of forecasting accuracy, both in changes of and levels of inflation. In general a more refined variant of a $\mathrm{P}^{*}$-type model cannot be beaten by a model based on pure past information.

A recent trend in the econometric literature has been the comparison of predictive accuracy among forecasting models. This method of forecast evaluation extends the analysis beyond RMSE measures because it tests for differences in the actual predictive power of the models that are being compared. Diebold and Mariano (1995) suggest a technique which allows for the testing of the significance of differences in forecasts. The basic methodology is presented in Appendix A3, while the results are presented in Table 5 below.

Table 5: Results from the Diebold-Mariano approach

\begin{tabular}{|l|l|l|l|}
\hline \multicolumn{4}{|l|}{ S statistic for forecasts over different horizons } \\
\hline & 1-qtr ahead & 4-qtrs ahead & 12 -qtrs ahead \\
\hline AR(4) & 2.953231 & -1.12125 & -0.61392 \\
\hline ARMA(4,4) & 3.384291 & -1.61562 & -0.44765 \\
\hline PHILLIPS & -0.57494 & -0.66036 & -0.85421 \\
\hline P*BASIC & -6.34648 & 2.293158 & -8.12123 \\
\hline P*HOD & 2.08268 & -6.45529 & 2.759139 \\
\hline
\end{tabular}

Null hypothesis: equal accuracy forecasts

Alternate hypothesis: Forecasts are significantly different in accuracy

The comparative distribution for the above statistics is a $\mathrm{N}(0,1)$, as explained in the appendix. The S-statistics above represent the tests of equality of forecast accuracy between the HPS $\mathrm{P}^{*}$ approach and the other four models. Interestingly the Phillips curve model provides significantly different forecasts over all three forecast horizons. The $\operatorname{AR}(4)$ and the $\operatorname{ARMA}(4,4)$ models' forecasts are significantly different from the HPS approach over the longer horizons indicating that the predictive power of the HPS approach is significantly different from a forecast based on pure past information over these horizons. $\mathrm{P}^{*}$-BASIC and the filter approach do not provide significantly different forecasts over all three horizons when compared to the HPS approach. Although the RMSE tests indicate that the Hodrick-Prescott filter approach provides the superior forecasts, the Diebold-Mariano tests do not indicate that these forecasts are significantly different from forecasts generated by the HPS approach. 


\section{Robustness}

Several robustness checks are performed. First, an interesting deviation from the standard approach is to test for the source of improvement in leading $\mathrm{P}^{*}$-type models. To do this, the HPS and HOD P* models are run with the velocity and output gaps interchanged consecutively. The results are displayed in Table 6 below. Panel A in Table 6 shows the results when the models are run in terms of accelerations of inflation while Panel B shows the results when the models are run in terms of levels of inflation.

If indeed using a filter approach extracts velocity and output gaps with superior explanatory power compared to P* HPS, then mixed models should outperform the HPS approach (in terms of adjusted R-squared values). To test this approach the mixed models (A',A",B', and B") in equations 15-18 are run against equation 10 (presented in section 5), and equation 14 below. Panel A in Table 6 below displays the results for the changes approach while panel B displays the results for the levels approach.

$\Delta \pi_{t}=\delta+\beta_{1}\left(v-v^{*}\right)_{t-1} H P S+\beta_{2}\left(y^{*}-y\right)_{t-1} H P S+\delta_{1} \Delta \pi_{t-1}+\delta_{2} \Delta \pi_{t-2}+\delta_{3} \Delta \pi_{t-3}+\delta_{4} \Delta \pi_{t-4}$ $+\mu_{t}$

Mixed Model $A^{\prime}: \pi_{t}=\delta+\beta_{1}\left(v-v^{*}\right)_{t-1} H O D+\beta_{2}\left(y^{*}-y\right)_{t-1} H P S+\delta_{1} \Delta \pi_{t-1}+\delta_{2} \Delta \pi_{t-2}+$ $\delta_{3} \Delta \pi_{t-3}+\delta_{4} \Delta \pi_{t-4}+\mu_{t}$

Mixed Model B': $\pi_{t}=\delta+\beta_{1}\left(v-v^{*}\right)_{t-1} H O D+\beta_{2}\left(y^{*}-y\right)_{t-1} H P S+\delta_{1} \pi_{t-1}+\delta_{2} \pi_{t-2}+\delta_{3} \pi_{t-3}$ $+\delta_{4} \pi_{t-4}+\mu_{t}$

Mixed Model A": $\pi_{t}=\alpha+\beta_{1}\left(v-v^{*}\right)_{t-1} H P S+\beta_{2}\left(y^{*}-y\right)_{t-1} H O D+\delta_{1} \Delta \pi_{t-1}+\delta_{2} \Delta \pi_{t-2}+$ $\delta_{3} \Delta \pi_{t-3}+\delta_{4} \Delta \pi_{t-4}+\mu_{t}$

Mixed Model B": $\pi_{t}=\alpha+\beta_{1}\left(v-v^{*}\right)_{t-1} H P S+\beta_{2}\left(y^{*}-y\right)_{t-1} H O D+\delta_{1} \pi_{t-1}+\delta_{2} \pi_{t-2}+\delta_{3} \pi_{t-3}$ $+\delta_{4} \pi_{t-4}+\mu_{t}$ 
Table 6: HPS P* versus mixed models

\begin{tabular}{|c|c|c|c|}
\hline \multicolumn{4}{|c|}{ PANEL $A$} \\
\hline \multicolumn{4}{|c|}{$\begin{array}{c}\text { Dependent variable is change in inflation rate: independent variables are changes in } \\
\text { inflation (In-sample) }\end{array}$} \\
\hline Model & HPS P* & Mixed model A' & Mixed Model B' \\
\hline$\delta$ & $\begin{array}{c}0.201764 \\
(1.535725)\end{array}$ & $\begin{array}{c}0.023005 \\
(0.222347) \\
\end{array}$ & $\begin{array}{c}\mathbf{0 . 2 6 1 4 0 6} \\
(2.114013) \\
\end{array}$ \\
\hline$\left(v-v^{*}\right) H P S_{t-1}$ & $\begin{array}{l}-29.98755 \\
(-1.784007)\end{array}$ & $\begin{array}{c}-\mathbf{5 8 . 1 0 8 5 2} \\
(-3.731277) \\
\end{array}$ & \\
\hline$\left(y^{*}-y\right) H P S_{t-1}$ & $\begin{array}{l}-11.71779 \\
(-2.568548)\end{array}$ & & $\begin{array}{c}-15.22466 \\
(-3.676460) \\
\end{array}$ \\
\hline$\left(v-v^{*}\right) H O D_{t-1}$ & & & $\begin{array}{c}-104.3773 \\
(-3.480518) \\
\end{array}$ \\
\hline$\left(y-y^{*}\right) H O D_{t-1}$ & & $\begin{array}{c}-27.72465 \\
(-4.038294) \\
\end{array}$ & \\
\hline$\Delta \pi_{t-1}$ & $\begin{array}{c}-0.444628 \\
(-4.786594)\end{array}$ & $\begin{array}{c}-0.499517 \\
(-5.501491) \\
\end{array}$ & $\begin{array}{r}-0.467549 \\
(-5.207471) \\
\end{array}$ \\
\hline$\Delta \pi_{t-2}$ & $\begin{array}{c}-0.310001 \\
(-3.089018)\end{array}$ & $\begin{array}{c}-0.369548 \\
(-3.789201) \\
\end{array}$ & $\begin{array}{c}-0.311748 \\
(-3.227720) \\
\end{array}$ \\
\hline$\Delta \pi_{t-3}$ & $\begin{array}{c}-0.177279 \\
(-1.756701) \\
\end{array}$ & $\begin{array}{c}-0.234453 \\
(-2.402894) \\
\end{array}$ & $\begin{array}{c}-0.162628 \\
(-1.673393) \\
\end{array}$ \\
\hline$\Delta \pi_{t-4}$ & $\begin{array}{c}0.096088 \\
(1.029613)\end{array}$ & $\begin{array}{c}0.055486 \\
(0.618330) \\
\end{array}$ & $\begin{array}{c}0.120941 \\
(1.340665) \\
\end{array}$ \\
\hline $\begin{array}{c}\text { Adjusted } \\
\text { R-squared }\end{array}$ & 0.21 & 0.27 & 0.27 \\
\hline \multicolumn{4}{|c|}{ PANEL B } \\
\hline \multicolumn{4}{|c|}{$\begin{array}{c}\text { Dependent variable is levels of inflation rate: independent variables are levels of } \\
\text { inflation (In-sample) }\end{array}$} \\
\hline Model & HPS P* & Mixed Model A" & Mixed Model B" \\
\hline$\delta$ & $\begin{array}{c}0.2132 \\
(0.8407) \\
\end{array}$ & $\begin{array}{c}0.194626 \\
(0.876678) \\
\end{array}$ & $\begin{array}{c}0.429544 \\
(2.642001)^{*}\end{array}$ \\
\hline$\left(v-v^{*}\right) H P S_{t-1}$ & $\begin{array}{l}-28.7542 \\
(-1.5159) \\
\end{array}$ & & $\begin{array}{c}-13.67479 \\
(-2.571726) *\end{array}$ \\
\hline$\left(y^{*}-y\right) H P S_{t-1}$ & $\begin{array}{c}-13.3277 \\
(-3.0567)^{*}\end{array}$ & $\begin{array}{c}-17.66042 \\
(-4.187511) *\end{array}$ & \\
\hline$\left(v-v^{*}\right) H O D_{t-1}$ & & $\begin{array}{c}-103.9247 \\
(-3.250237) *\end{array}$ & \\
\hline$\left(y-y^{*}\right) H O D_{t-1}$ & & & $\begin{array}{c}-27.94137 \\
(-5.204373) *\end{array}$ \\
\hline$\pi_{t-1}$ & $\begin{array}{c}0.5366 \\
(\mathbf{5 . 8 9 1 7}) * \\
\end{array}$ & $\begin{array}{c}0.513334 \\
(5.814903)^{*}\end{array}$ & $\begin{array}{c}0.451833 \\
(6.180847)^{*} \\
\end{array}$ \\
\hline$\pi_{t-2}$ & $\begin{array}{c}0.1247 \\
(1.1946) \\
\end{array}$ & $\begin{array}{c}0.148146 \\
(1.467012) \\
\end{array}$ & $\begin{array}{c}0.108625 \\
(1.346231) \\
\end{array}$ \\
\hline$\pi_{t-3}$ & $\begin{array}{c}0.1216 \\
(1.1662)\end{array}$ & $\begin{array}{c}0.139682 \\
(1.385895)\end{array}$ & $\begin{array}{c}0.097278 \\
(1.203505)\end{array}$ \\
\hline $\boldsymbol{\pi}_{t-4}$ & $\begin{array}{c}0.2215 \\
(2.3745)^{*}\end{array}$ & $\begin{array}{c}0.224730 \\
(2.495593) * \\
\end{array}$ & $\begin{array}{c}0.260501 \\
(3.579481)^{*}\end{array}$ \\
\hline $\begin{array}{c}\text { Adjusted } \\
\text { R-squared }\end{array}$ & 0.80 & 0.81 & 0.83 \\
\hline
\end{tabular}

t-statistics significant at $5 \%$ level or less

As discussed earlier, and that is immediately apparent in Table 6 above, the velocity gap under the HPS approach is insignificant in explaining both accelerations in and levels of inflation. The following short discussion refers to panel A of Table 6 above. Mixed model A' includes the HPS velocity gap, and the HOD output gap. Interestingly, in this formulation, the HPS velocity gap becomes significant. The HOD output gap has double the explanatory power of the HPS 
output gap and the adjusted R-squared for this model is higher than the unadulterated HPS approach. Next a mixed model that has the HOD velocity gap and the HPS output gap is tested against the pure HPS approach (model B'). Both gaps are significant and the model has the same adjusted R-squared as model A'. The mixed models in panel A out-perform the HPS model (in terms of adjusted R-squared values).

Panel $\mathrm{B}$ displays the results for the comparisons between equation 10, and the mixed models represented in equations 15 and 17. The results are very similar to panel A - the mixed models outperform the pure HPS approach, in terms of adjusted R-squared values. The conclusion echoes earlier findings in this paper - the HPS approach does not adequately capture the effect of money on inflation. Both mixed models and the pure HOD approach capture the effect of the velocity gap better. 
Table 7: Tests for the Nixon dummy

\begin{tabular}{|c|c|c|c|}
\hline \multicolumn{4}{|c|}{ PANEL A (TESTING FOR THE NIXON DUMMY } \\
\hline \multicolumn{4}{|c|}{$\begin{array}{c}\text { Dependent variable is change in inflation rate: independent variables are } \\
\text { changes in inflation (In-sample) }\end{array}$} \\
\hline Model & HPS P* & $P * B A S I C$ & $P * H O D$ \\
\hline$\delta$ & $\begin{array}{c}0.207688 \\
(1.660459)\end{array}$ & $\begin{array}{c}0.002681 \\
(0.024825)\end{array}$ & $\begin{array}{c}0.029917 \\
(0.281188)\end{array}$ \\
\hline$\left(p-p^{*}\right)_{t-1}$ & $\begin{array}{c}-11.92852 \\
(-2.959013) *\end{array}$ & $\begin{array}{c}-8.090476 \\
(-2.489125)^{*}\end{array}$ & $\begin{array}{c}-24.63932 \\
(-3.125330) *\end{array}$ \\
\hline$N I X D$ & $\begin{array}{c}0.986384 \\
(1.633021)\end{array}$ & $\begin{array}{c}1.203903 \\
(2.022018)^{*}\end{array}$ & $\begin{array}{c}0.702859 \\
(1.110336)\end{array}$ \\
\hline$\pi_{t-1}$ & $\begin{array}{c}-0.449344 \\
(-4.877850) *\end{array}$ & $\begin{array}{l}-0.427334 \\
(-4.643996)\end{array}$ & $\begin{array}{c}-0.456992 \\
(-4.963736) *\end{array}$ \\
\hline$\pi_{t-2}$ & $\begin{array}{c}-0.310129 \\
(-3.129537)^{*}\end{array}$ & $\begin{array}{c}-0.280701 \\
(-2.854520)^{*}\end{array}$ & $\begin{array}{c}-0.323710 \\
(-3.248594) *\end{array}$ \\
\hline$\pi_{t-3}$ & $\begin{array}{c}-0.160973 \\
(-1.598629)\end{array}$ & $\begin{array}{l}-0.126106 \\
(-1.270493)\end{array}$ & $\begin{array}{c}-0.183912 \\
(-1.794030)\end{array}$ \\
\hline$\pi_{t-4}$ & $\begin{array}{c}0.115201 \\
(1.229788) \\
\end{array}$ & $\begin{array}{c}0.143481 \\
(1.544206) \\
\end{array}$ & $\begin{array}{c}0.096675 \\
(1.019300) \\
\end{array}$ \\
\hline $\begin{array}{l}\text { Adjusted } \\
\text { R-squared }\end{array}$ & 0.22 & 0.21 & 0.23 \\
\hline \multicolumn{4}{|c|}{ PANEL B (TESTING FOR THE NIXON DUMMY) } \\
\hline \multicolumn{4}{|c|}{$\begin{array}{c}\text { Dependent variable is levels of inflation rate: independent variables are } \\
\text { levels of inflation (In-sample) }\end{array}$} \\
\hline Model & HPS P* & $P * B A S I C$ & $P * H O D$ \\
\hline$\delta$ & $\begin{array}{c}0.224333 \\
(0.985865)\end{array}$ & $\begin{array}{c}0.455842 \\
(1.944587)\end{array}$ & $\begin{array}{c}0.295982 \\
(1.316532)\end{array}$ \\
\hline$\left(p-p^{*}\right)_{t-1}$ & $\begin{array}{c}-13.68675 \\
(-3.402534)^{*}\end{array}$ & $\begin{array}{c}-11.34644 \\
(-3.554454)^{*}\end{array}$ & $\begin{array}{c}-28.11221 \\
(-3.877039)^{*}\end{array}$ \\
\hline$N I X D$ & $\begin{array}{c}0.830103 \\
(1.367898)\end{array}$ & $\begin{array}{c}0.532824 \\
(0.854537)\end{array}$ & $\begin{array}{c}0.264886 \\
(0.416169) \\
\end{array}$ \\
\hline$\pi_{t-1}$ & $\begin{array}{c}0.528864 \\
(5.839393)^{*}\end{array}$ & $\begin{array}{c}0.509856 \\
(5.584689)^{*}\end{array}$ & $\begin{array}{c}0.504516 \\
(5.585837)^{*}\end{array}$ \\
\hline$\pi_{t-2}$ & $\begin{array}{c}0.126343 \\
(1.221534)\end{array}$ & $\begin{array}{c}0.107076 \\
(1.037674)\end{array}$ & $\begin{array}{c}0.106095 \\
(1.038150)\end{array}$ \\
\hline$\pi_{t-3}$ & $\begin{array}{c}0.133334 \\
(1.279427)\end{array}$ & $\begin{array}{c}0.108346 \\
(1.045058)\end{array}$ & $\begin{array}{c}0.109056 \\
(1.062041)\end{array}$ \\
\hline$\pi_{t-4}$ & $\begin{array}{c}0.215205 \\
(2.315999)^{*}\end{array}$ & $\begin{array}{c}0.173994 \\
(1.954699)\end{array}$ & $\begin{array}{c}0.221175 \\
(2.429669)^{*}\end{array}$ \\
\hline $\begin{array}{c}\text { Adjusted } \\
\text { R-squared }\end{array}$ & 0.80 & 0.81 & 0.81 \\
\hline
\end{tabular}

t-statistics significant at $5 \%$ or less.

As a second robustness check, the forecasting horizon (for all models) is increased to a $\mathrm{k}=12$ horizon over the period 1990:1 2003:4. As mentioned earlier, to evaluate the best forecast in any horizon, previous studies such as those by Christiano (1989), HPS (1991, and Fisher (1995) are followed in using the root mean square error (RMSE) measure. Table five presents the RMSE measures for all the models over the $\mathrm{k}=12$ horizons. The filter approach again outperforms the other models in having the lowest RMSE values. 
As a third robustness check, the models are tested with an explicit variable that captures stagflation. The models are extended with the inclusion of the Nixon dummy. This allows for the control of the OPEC oil crisis when the over-riding concern was stagflation. The Nixon dummy however, turns out to be insignificant for all formulations of the $\mathrm{P}$ *-type models, seemingly indicating that the price gaps are able to capture the supply shocks represented by the OPEC oil crisis.

As a final robustness check, the p-star models are tested using divisia aggregates. Divisia aggregates are different from simple sum aggregates because they are weighted by the returns to the components. Since the Hodrick Prescott method involves extracting a trend in velocity that captures movements over time, it is expected that the smoothed trend will capture innovations in money. Divisia aggregates are measured based on weighting of different innovations. If the HP filter has done a good job, then it is expected that the velocity gap should be insignificant when divisia aggregates are used because divisia aggregates have already accounted for shifts in velocity. The results are presented in Table 8 below (the regression samples are adjusted for the availability of divisia aggregate data). In turns out however, that for both the levels approach and the changes approach, both pgaphod and vgaphod are still significant in explaining inflation. This suggests that velocity gaps capture information beyond monetary innovations that are encompassed in divisia aggregates. 
Table 8: Robustness checks with divisia aggregates

\begin{tabular}{|c|c|c|c|}
\hline \multicolumn{4}{|c|}{ Price Gaps Based on Divisia Aggregates } \\
\hline \multicolumn{4}{|c|}{$\begin{array}{c}\text { Dependent variable is change in inflation rate: independent variables are changes in inflation } \\
\text { (Sample is 1960:1 1992:4) }\end{array}$} \\
\hline Model & HPS P* & $P *$ Basic & $P *-H P$ filter \\
\hline$\delta$ & $\begin{array}{c}0.241607 \\
(1.842982) \\
\end{array}$ & $\begin{array}{c}0.795775 \\
(0.795094)\end{array}$ & $\begin{array}{c}0.007997 \\
(0.073370) \\
\end{array}$ \\
\hline$\left(v-v^{*}\right) H P S_{t-1}$ & $\begin{array}{l}-2.147260 \\
(-0.592456)\end{array}$ & & \\
\hline$\left(y^{*}-y\right) H P S_{t-1}$ & $\begin{array}{c}-13.82529 \\
(-3.085693)\end{array}$ & & \\
\hline$\left(v-v^{*}\right) H O D_{t-1}$ & & & $\begin{array}{c}-118.3765 \\
(-3.370047)\end{array}$ \\
\hline$\left(y-y^{*}\right) H O D_{t-1}$ & & & $\begin{array}{l}-5.431309 \\
(-0.789061)\end{array}$ \\
\hline$(v-v *) B A S I C C_{t-1}$ & & $\begin{array}{c}-4.453175 \\
(-1.105657)\end{array}$ & \\
\hline$\left(y^{*}-y\right) B_{A S I C}{ }_{t-1}$ & & $\begin{array}{c}-8.519857 \\
(-2.532160)\end{array}$ & \\
\hline$\Delta \pi_{t-1}$ & $\begin{array}{c}-0.440903 \\
(-4.686397)\end{array}$ & $\begin{array}{c}-0.416312 \\
(-4.425117)\end{array}$ & $\begin{array}{c}-0.396306 \\
(-4.315573)\end{array}$ \\
\hline$\Delta \pi_{t-2}$ & $\begin{array}{c}-0.318882 \\
(-3.138784)\end{array}$ & $\begin{array}{c}-0.286326 \\
(-2.836243)\end{array}$ & $\begin{array}{c}-0.243168 \\
(-2.468316)\end{array}$ \\
\hline$\Delta \pi_{t-3}$ & $\begin{array}{c}-0.195449 \\
(-1.920400)\end{array}$ & $\begin{array}{c}-0.160502 \\
(-1.591337)\end{array}$ & $\begin{array}{c}-0.097979 \\
(-0.987381)\end{array}$ \\
\hline$\Delta \pi_{t-4}$ & $\begin{array}{c}0.077009 \\
(0.818658)\end{array}$ & $\begin{array}{c}0.102569 \\
(1.091468)\end{array}$ & $\begin{array}{c}0.167966 \\
(1.800289)\end{array}$ \\
\hline $\begin{array}{l}\text { Adjusted } \\
\text { R-squared }\end{array}$ & 0.19 & 0.17 & 0.19 \\
\hline \multicolumn{4}{|c|}{$\begin{array}{c}\text { Price Gaps Based on Divisia Aggregates } \\
\end{array}$} \\
\hline \multicolumn{4}{|c|}{$\begin{array}{l}\text { Dependent variable is levels of inflation rate: independent variables are levels of inflation rate } \\
\text { (Sample is 1960:1 1992:4) }\end{array}$} \\
\hline Model & HPS P* & $P *$ Basic & $P *-H P$ filter \\
\hline$\delta$ & $\begin{array}{c}0.375381 \\
(1.626217) \\
\end{array}$ & $\begin{array}{c}0.470492 \\
(0.482971) \\
\end{array}$ & $\begin{array}{c}0.289886 \\
(1.232163) \\
\end{array}$ \\
\hline$\left(v-v^{*}\right) H P S_{t-1}$ & $\begin{array}{c}-1.705492 \\
(-0.462429) \\
\end{array}$ & & \\
\hline$\left(y^{*}-y\right) H P S_{t-1}$ & $\begin{array}{c}-14.31654 \\
(-3.264822)\end{array}$ & & \\
\hline$\left(v-v^{*}\right) H O D_{t-1}$ & & & $\begin{array}{c}-109.3706 \\
(-3.062224)\end{array}$ \\
\hline$\left(y-y^{*}\right) H O D_{t-1}$ & & & $\begin{array}{l}-10.92888 \\
(-1.609495)\end{array}$ \\
\hline$\left(v-v^{*}\right) B A S I C_{t-1}$ & & $\begin{array}{c}-1.351374 \\
(-0.328800)\end{array}$ & \\
\hline$\left(y^{*}-y\right) B A S I C C_{t-1}$ & & $\begin{array}{l}-12.30784 \\
(-3.687289)\end{array}$ & \\
\hline$\pi_{t-1}$ & $\begin{array}{c}0.537325 \\
(5.844902)\end{array}$ & $\begin{array}{c}0.509516 \\
(5.532087)\end{array}$ & $\begin{array}{c}0.556633 \\
(6.040949)\end{array}$ \\
\hline$\pi_{t-2}$ & $\begin{array}{c}0.108345 \\
(1.034381)\end{array}$ & $\begin{array}{c}0.093430 \\
(0.901896)\end{array}$ & $\begin{array}{c}0.119458 \\
(1.127784)\end{array}$ \\
\hline$\pi_{t-3}$ & $\begin{array}{c}0.108239 \\
(1.032297)\end{array}$ & $\begin{array}{c}0.092051 \\
(0.890047)\end{array}$ & $\begin{array}{c}0.108426 \\
(1.025472) \\
\end{array}$ \\
\hline$\pi_{t-4}$ & $\begin{array}{c}0.218351 \\
(2.315554)\end{array}$ & $\begin{array}{c}0.181541 \\
(2.019761)\end{array}$ & $\begin{array}{c}0.154904 \\
(1.695314)\end{array}$ \\
\hline Adjusted R-squared & 0.79 & 0.80 & 0.79 \\
\hline
\end{tabular}




\section{Conclusion}

Economic literature is filled with different models to forecast inflation. The literature has suggested that the Fed should target inflation forecasts rather than the actual inflation rate itself, because of the lag between monetary policy and the effect on inflation. The $\mathrm{P} *$ approach was hailed by many as an innovative approach to forecasting inflation. Redefining the velocity gap and the output gap in the model by using a Hodrick-Prescott smoothing method gains better forecasts for a one-quarter-ahead horizon. However, the $\mathrm{P}^{*}$ model gained fame because of its forecasting capability over the longer horizons between two and three years.

This paper finds, however, that $\mathrm{P}^{*}$-HOD improves upon $\mathrm{P}^{*}$-HPS, in terms of forecast accuracy. In both the accelerations and levels of inflation specification, the HOD price gap has double the explanatory power of the HPS gap. Moreover, when the gap is separated into the velocity and output gaps, the HPS velocity gap is insignificant. This seems to indicate that the HPS model is unable to capture the effect of money on inflation, and the significance of its price gap stems from supply side effects.

The difference in magnitude displayed by the HOD price gap has important monetary policy implications, because of the monetary policy response to the correct identification of the gap. The direction of the gap is also important - if the gap between $\mathrm{P}^{*}$ and $\mathrm{P}$ is positive, this indicates that inflation will accelerate in the future to meet $\mathrm{P}^{*}$. If the Fed wishes to control inflation, they would then need to increase the interest rate. One the other hand, if the gap is negative, inflation will decelerate and monetary loosening may be in order. Only the $\mathrm{P}^{*}$ approach with the HodrickPrescott filter displays the importance of the money-side shock in explaining inflation. Ultimately, this paper provides support for the link between money and prices - naïve models based on past information cannot beat the $\mathrm{P}^{*}$-type models.

\section{LITERATURE CITED}

Bernanke, Ben S. and Michael Woodford (1997), "Inflation Forecasts and Monetary Policy", Journal of Money, Credit and Banking, Vol. 29, No. 4, (November 1997 Part Two).

Bomhoff, Eduard J., (1990), "Stability of Velocity in the G-7 Countries: A Kalman Filter

Approach", International Monetary Fund IMF Working Papers, 90/80.

Christiano, Lawrence J. (1989). "P*: Not the Inflation Forecaster's Holy Grail,” Quarterly

Review (Fall), Federal Reserve Bank of Minneapolis.

Christiano, Lawrence, and Lars Ljungqvist, (1988), "Money Does Granger-Cause Output in the Bivariate Money-Output Relation”, Journal of Monetary Economics v22, n2 (September): 217-35 
Diebold, Francis and Roberto Mariano (1999). “Comparing Predictive Accuracy”, Economic Forecasting, Vol. 2 263-73.

Ebrill, Liam and Steven M. Fries, (1991). "Broad Money Growth and Inflation in the United States", IMF Staff Papers, Vol. 38, No. 4, December.

Fisher, Douglas and Adrian R. Fleissig (1995). "Monetary Aggregates and the P* Model of Inflation In the United States", Working Paper.

Hallman, Jeffrey J. and Richard G. Anderson (1993). "Has the Long-Run Velocity of M2 Shifted? Evidence from the P* Model", Economic Review, Federal Reserve Bank of Cleveland 29(1).

Hallman, Jeffrey J., Richard D. Porter and David H. Small (1991). "Is the Price Level Tied to the M2 Aggregate in the Long Run?" American Economic Review (September).

Hoeller, Peter, and Pierre Poret, "P-Star as an Indicator of Inflationary Pressure", OECD Department of Economics and Statistics Working Papers, March 1991.

Kool, Clemens, and John Tatom, (1994), "The P-Star Model In Five Small Open Economies" Federal Reserve Bank of St. Louis Review (May/June), pp. 11-29.

Maddala, G.S. Introduction to Econometrics, Second Edition, 1992, Macmillan Publishing Company.

Masih, Abul, M. and Rumi Masih, (1988), “Does Money Cause Prices or the Other Way Around? Multi-Country Econometric Evidence Including Error-Correction Modeling from South-East Asia", Journal of Economic Studies v25, n2-3: 138-60

Orphanides, Athanasios and Richard Porter, (2000), "P* Revisited: Money-Based Inflation Forecasts with a Changing Equilibrium Velocity". Journal of Economics and Business v52, n1-2 (Jan.-April): 87-100 
Pecchenino, R.A., and Robert H. Rasche, (November, 1990), "P*-Type Models: Evaluation and Forecasts", International Journal of Forecasting.

Razzak, W.A. (March, 2002). "Monetary Policy and Forecasting Inflation with and without the Output Gap", Reserve Bank of New Zealand Discussion Paper Series.

Tatom, John A. (1990). "The P-Star Approach to the Link Between Money and Prices", Working Paper, Federal Reserve Bank of St. Louis. 
Appendix 1: Tests for structural breaks in velocity and output gaps under the three $P *$ type approaches

\begin{tabular}{|l|c|c|}
\hline & Break & Maximal \\
& Dates & f-stat \\
\hline vgapbasic & $1995: 1$ & 10.21069 \\
\hline ygapbasic & $1973: 3$ & 4.835721 \\
\hline vagphps & $1995: 1$ & 11.07638 \\
\hline ygaphps & $1960: 3$ & 4.521267 \\
\hline vgaphod & $2001: 3$ & 3.94824 \\
\hline ygaphod & $1960: 3$ & 4.592403 \\
\hline
\end{tabular}

Based on bootstrapping techniques prescribed by Lawrence Christiano (1988), critical F statistics (for 5000 iterations) indicate no structural breaks for HOD gaps, but indicate the presence of a structural break for vgapbasic and vgaphps at the indicated dates. 
Appendix 2: Velocity gaps under the HPS and HOD approaches over time

vgaphps

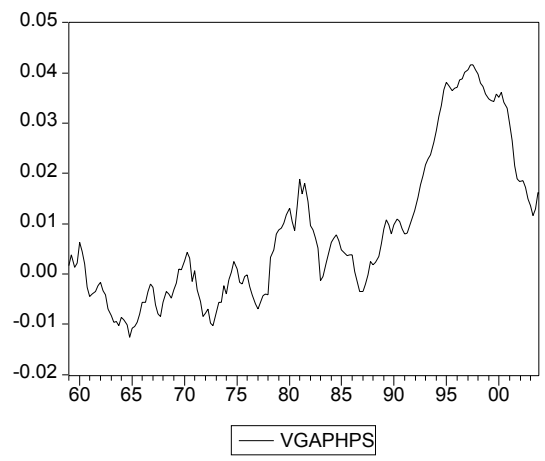

vgaphod

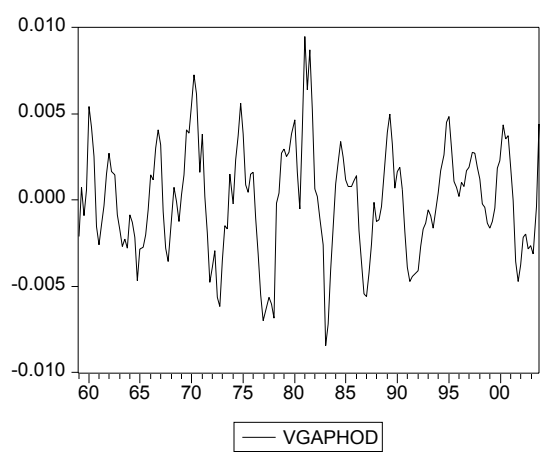

ygaphps

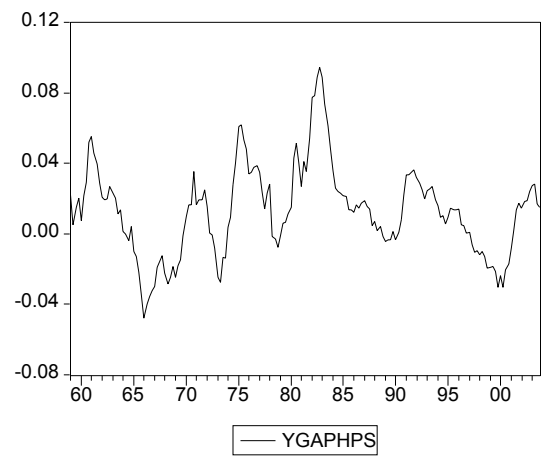

ygaphod

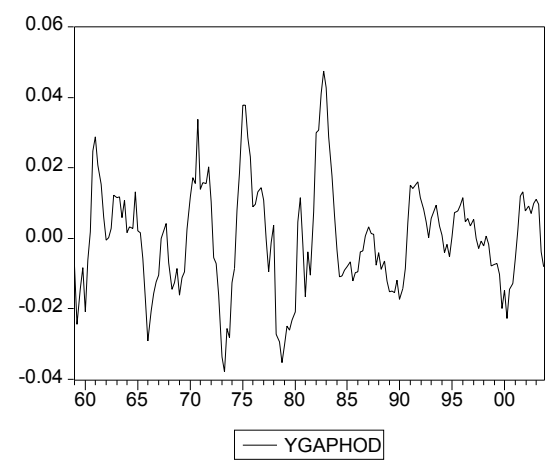

Gaps calculated under the Hodrick-Prescott filter approach clearly indicate mean reversion around 0. Calculating the deviations from trend using the Hodrick-Prescott filter approach defines a smoother set of deviations that improve forecasting ability. 


\section{Appendix 3: A Brief Explanation of the Diebold Mariano test for the null hypothesis of equal accuracy in two forecasts.}

Consider two forecasts: $\left\{\hat{y}_{i t}\right\}_{t=1}^{T}$ and $\left\{\hat{y}_{j t}\right\}_{t=1}^{T}$ of the time series $\left\{\hat{y}_{t}\right\}_{t=1}^{T}$. The associated forecast errors are $\left\{\hat{e}_{i t}\right\}_{t=1}^{T}$ and $\left\{\hat{e}_{j t}\right\}_{t=1}^{T}$. A time-t loss function associated with a forecast $i$ is identified as $\mathrm{g}\left(\hat{y}_{t}, \hat{y_{i t}}\right)$. In most cases the loss function will be a direct function of the forecast error, that is $\mathrm{g}\left(\hat{y_{t}}, \hat{y_{i t}}\right)=\mathrm{g}\left(\mathrm{e}_{i t}\right)$. The loss function is hereafter referred to as $\mathrm{g}\left(\mathrm{e}_{i t}\right)$.

The hypotheses associated with the D-M test are as follows:

$\mathrm{H}_{0}=\mathrm{E}\left[\mathrm{g}\left(\mathrm{e}_{i t}\right)\right]=\mathrm{E}\left[\mathrm{g}\left(\mathrm{e}_{j t}\right)\right]$ or $\mathrm{E}\left[\mathrm{d}_{t}\right]=0$, where $\mathrm{d}_{t} \equiv\left[\mathrm{g}\left(\mathrm{e}_{i t}\right)-\mathrm{g}\left(\mathrm{e}_{j t}\right)\right]$ is the loss differential. The null hypothesis then states that the two forecasts are equally accurate, or that the population mean of the series of loss differentials over time $t$ is 0 .

The path of the loss differential series is $\left\{d_{t}\right\}_{t=1}^{T}$. If this series is covariance stationary and short memory, then standard results are used to deduce the asymptotic distribution of its mean.

$\sqrt{T}(\bar{d}-\mu) \stackrel{d}{\longrightarrow} N\left(0,2 \pi f_{d}(0)\right)$

where

$\bar{d}=\frac{1}{T} \sum\left[\mathrm{g}\left(\mathrm{e}_{\mathrm{it}}\right)-\mathrm{g}\left(\mathrm{e}_{j t}\right)\right]$

is the sample mean loss differential,

$$
f_{d}(0)=\frac{1}{2 \pi} \sum_{\tau=-\infty}^{\infty} \gamma_{d}(\tau)
$$

is the spectral density function of the loss differential at frequency 0 ,

$\gamma_{d}(\tau)=E\left[\left(d_{t}-\mu\right)\left(d_{t-\tau}-\mu\right)\right.$

is the autocovariance of the loss differential at displacement $\tau$, and $\mu$ is the population mean loss differential. 
In large samples, the sample mean loss differential $\bar{d}$ is approximately normally distributed with mean $\mu$, and variance $2 \pi f_{d}(0) / \mathrm{T}$. The $\mathrm{N}(0,1)$ statistic for testing the null hypothesis of equal forecast accuracy is then the following s-statistic

$$
S_{1}=\frac{\bar{d}}{\sqrt{\frac{2 \pi \hat{f}(0)}{T}}},
$$

where $f(0)$ is a consistent estimator of $f_{d}(0)$. Diebold and Mariano show that a consistent estimator of $2 \pi f_{d}(0)$ is found by taking a weighted sum of the available sample autocovariances,

$2 \pi \hat{f_{d}}(0)=\sum_{\tau=-(T-1)}^{(T-1)} 1\left(\frac{\tau}{S(T)}\right) \hat{\gamma}_{d}(\tau)$

where

$\gamma_{d}(\tau)=\frac{1}{T} \sum\left(d_{t}-\bar{d}\right)\left(d_{T-|\tau|}-\bar{d}\right)$

$1(\tau / S(T))$ is the lag window and $\mathrm{S}(\mathrm{T})$ is the truncation lag. 


\title{
Chapter 2
}

\section{Re-examining the Relationship Between Financial Development and Growth - A Developing Country Perspective}

\begin{abstract}
Many studies have examined the relationship between economic growth and finance. Some of the continuing issues in this area include the choice of a clear proxy for financial development and the question of causality between financial development and economic growth. This paper attempts to answer these questions from a developing country perspective, while controlling for financial repression. The proxy of choice is the ratio of currency outside the banking system to real output. This proxy is unique in that it is related to the degree of financial repression, and thus relates differently to economic growth depending on the level of financial development. The statistics support the hypothesis of the U-shaped behaviour of $\mathrm{CB}$ with financial liberalization. The empirical results show that $\mathrm{CB}$ relates negatively to growth in countries that are less financially liberalized and positively with growth in countries that are more financially liberalized. The literature has used real interest rates as a measure of financial repression. An innovative measure of financial repression is then proposed that combines the use of currency inside banks and currency outside banks, and is tested concurrently with a broad money depth measure. The study is carried out using a panel approach, and the sample is also divided into different geographical regions, in order to see whether the relationship differs between geographical regions. The study concludes that there is overwhelming evidence that financial repression, which is indicative of financial underdevelopment is negatively related to growth. Recent econometric Granger causality methods are then applied to test the finance-growth hypotheses.
\end{abstract}

JEL Classification: O11,O57

Developing countries have been engaging in financial reforms for the past two decades now. The purpose of this study is to look at the empirical relationship between financial development and economic development from a developing country perspective, while controlling for geographical proximity. It must be noted that the relationship between financial development and growth is by no means widely accepted.

Lillian Kamal, Department of Economics, West Virginia University, P.O. Box 6025, Morgantown, WV 26506.E-mail: ltkamal@mail.wvu.edu 
Robert Lucas (1988) has suggested that the link has been "badly over-stressed". Stern (1989) writes a review of development economics, but does not mention the financial system. However, financial reforms in most developing countries are part and parcel of a move towards establishing economies that are more heavily private sector led. This paper then attempts to highlight the relationship, if one exists, but purely from a developing country perspective. To this end, the effect of financial development on growth is tested while controlling for financial repression, and geographical proximity. The rest of the paper is organized as follows: section 1 discusses past studies in the area, and discusses the proxies of choice within this paper. Section 2 is the methodology section; sections 3 and 4 present results and robustness checks, and section 5 presents concluding remarks.

\section{I) Theory}

The literature in this area is vast. The seminal work in the area was by Goldsmith (1969). In his paper, he measured the level of financial development by using the value of financial intermediary assets relative to GNP. The key assumption here was that the size of the financial system has a positive correlation with the level of financial services provided. This study was carried out on 35 countries with pre-1964 data, and also did not control for other factors influencing economic growth. Goldsmith was able to find evidence that, as countries develop, the size of their banking sectors tend to become larger relative to national output. Overall, this study did not attempt to make any causal relationships. It simply indicated a correlation between financial development and economic development. Some criticism has been aimed at the measure Goldsmith chose for financial development - critics argue that the size of the formal financial system may not be captured well by this measure.

McKinnon (1973) and Shaw (1973) were among the first to provide a theoretical background for why financial development could cause growth. King and Levine (1993a,b) look at 77 countries and also systematically control for other factors affecting economic growth. They also look at the capital accumulation and productivity growth channels, and create new measures of the level of financial development.

Since then the literature has looked at financial development through measures of banking activity (King and Levine, 1993 a,b) and measures of stock market development (Atje and Jovanovic, 1993), and Levine and Zervos (1998). The continuous problem identified in the literature has been a measure that can adequately capture the degree of financial development in all its changing aspects. Several issues exist - the services provided by the financial system are diverse - these include mobilization of savings, diversification of risk, and management of the payment system. Secondly, the agents that provide these financial services are diverse - these include banks, securities markets, and insurance companies, among others (Andres, Ignacio, and Lopez-Salido, 1999). A third issue that has been tackled in a few instances in the literature is the fact that financial development also involves financial market deregulation, and this involves a reduced level of government restrictions, such as interest rate controls and price distortions in the financial sector.

Two strands have developed in this literature. The development of these opposing schools of thought is reminiscent of the chicken-egg problem. Patrick (1966) coined the terms for the two opposing hypotheses. One is the demand-following hypothesis that proposes that financial development responds passively to economic growth. The financial sector thus develops as a result of an increased demand for financial services that is fuelled by the growth of the real sector. The basic logic is as follows - as the real sector grows, there will be a greater demand by firms for external sources of finance. There then develops a role for financial 
intermediaries such as banks. Thus the banking sector evolves out of a need to match firms (borrowers) and households (savers). Clearly the causation in this case would run from economic growth to finance.

The supply-leading hypothesis proposes the polar opposite. Basically, this theory states that the creation of the financial sector occurs in advance of the demand for it. The supplyleading hypothesis stresses the importance of the financial sector in transferring funds between low-growth and high-growth sectors, and highlights the importance of the financial sector in causing an entrepreneurial response in these high-growth sectors. (Kar, and Pentecost, 2000). In this case, the causation runs from financial development to growth.

The direction of causality is vital for the choice of development strategy (Hurlin and Venet, 2004). If it is determined that the optimal allocation of resources within an economy is enhanced by the development of the financial system (supply-leading hypothesis), then development strategy should be centred around financial sector liberalization. For example, policy should be focused on the free entry of firms into the banking sector, controls on international capital movement should be lifted and interest rate ceilings should be removed. On the other hand, if it is determined that economic growth causes the development of the financial sector, development policy should be centred on other growth-enhancing policies.

What impact does the financial system theoretically have on an economy? To understand this link, one must first understand the functions that a financial system performs. Levine (1997) has listed five functions that a financial system performs. These are to:

1. assist the trading, hedging, diversification and pooling of risk,

2. allocate resources,

3. supervise managers,

4. mobilize savings, and

5. enhance the exchange of goods and services.

In general, the literature has presented two channels through which each of these financial functions can affect economic growth - the capital accumulation channel and the technological innovation channel. A financial system will alter the rate of capital accumulation by affecting the rate of savings, or by reallocating savings among new and different capital producing technologies. The financial system will also affect the rate of technological innovation and thus affect the steady state level of growth in an economy.

It is expected that from a developing country perspective, development of a financial system will affect savings mobilization initially. The logic of this idea is as follows: developing countries rely on the banking system. As the financial system develops, the banking system is able to provide varied instruments that allow the mobilization of savings in new ways. Savers are then able to take advantage of better financial instruments that provide them with a better riskreturn trade-off. Ultimately financial development means that savers can hold better portfolios.

But financial development is also expected to affect economic growth through savings mobilization in another way. Producers in an economy that is financially under-developed do not have access to multiple investors. There exists an informational asymmetry. Thus they produce at a scale that is economically inefficient. A developed financial system provides a better opportunity for the efficient exchange of resources between savers and firms. Firms can thus expand, and increase their production. As they produce at a larger economic scale, they also become more efficient and productivity is improves, raising the rate of economic growth. As Levine (1997) puts it, financial development can "profoundly affect economic development". 
Figure 1: The Theoretical Link Between Finance and Growth (Levine, 1997)

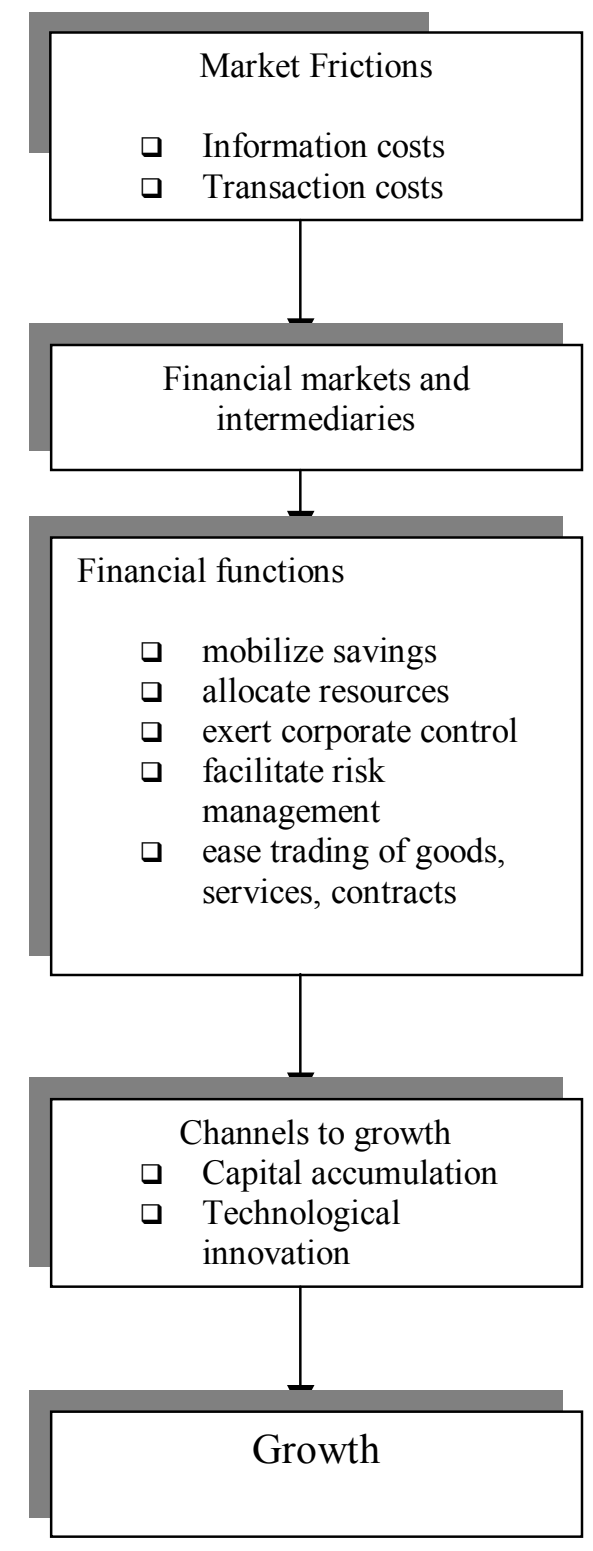

Given that development of the financial sector is expected to positively impact economic growth, there are factors that are often present in developing countries that can hinder the development of the finance sector. Governments may place regulations on the financial sector in the form of price distortions and restrictions in order to maintain the financial sector as a source of public finance. Examples of restrictions that often exist in developing countries are subsidized or directed credit, credit rationing, collusive contracts between public firms and banks, and interest rate ceilings on deposits (Creane, et al, 2003). These kind of distortions in a free financial sector are commonly referred to as "financial repression". Some studies have even gone as far as 
to link a strong degree of financial repression with a fall in real GDP growth of over one percentage point per year.

Giovanni and de Melo (1993) have defined financial repression as a combination of controls on international capital flows and restrictions on domestic interest rates. Typically researchers consider financial repression to be the product of artificially set interest rates that causes real interest rates to fall well below the rates of inflation. Traditionally, domestic real interest rates (henceforth referred to as RI) are used in the literature as a measure of financial repression. Government revenue is then calculated as the difference between the foreign and domestic cost of funds multiplied by the stock of government debt. Giovanni and de Melo (1993) find that the revenue that governments make from financial repression is substantial and in some cases is even comparable to the revenue from seigniorage. It is important to note that in the absence of international financial controls, most cases of domestic controls on interest rates could be bypassed foreign borrowing and lending. However, controls on domestic interest rates are often coupled with restrictions on international borrowing and lending and this leads to a compromised financial system.

The literature on the finance-growth relationship has utilized both the cross-sectional approach and the time series approach. Using a cross-sectional approach requires the averaging out of data over long time periods and then using the data in cross-sectional regressions that are aimed at explaining the cross-country variations in growth rates. These sorts of studies are then able to gauge the average effect of variables that affect economic growth rates. Apart from the seminal King and Levine (1993) paper, there are other studies by Gelb (1989), Roubini and Salai-Martin (1992), and Fry (1996) that all use a cross-sectional approach. However, cross-sectional studies have their fair share of critics. The users of this technique have themselves pointed out shortcomings with this approach. Evans (1995) has mentioned that there could be econometric problems associated with the heterogeneity of slope coefficients across countries.

The classic paper in the finance-growth literature is the King and Levine (1993) paper the study covers the 1960-89 period and focuses on 77 countries. The authors use various proxies for financial development, which are mostly monetary depth measures, and three growth variables (average growth rate of real GDP per capita, average growth rate of capital stock per capita, and a measure of total factor productivity). Levine's paper utilizes cross-country data, and as Levine himself alludes to, there are some problems with using this kind of data. There is the difficulty in establishing causality in cross-country data sets, and also the problem of average effects of financial development. This is, however, acceptable if one considers that the basic characteristics between the countries are similar in nature. A number of authors have decided to study time series data on individual countries - time series data has the advantage of allowing the researcher to search for possible long-term relationships such as cointegration that would illuminate the link between variables better.

Time series studies have not, however, clarified the relationship between finance and growth. De Gregorio and Guidotti (1995) who discuss the pros and cons of various financial development proxies, have actually found a negative relationship between finance and growth. Recent studies have begun to use panel data techniques to examine the issue. Beck and Levine (2002) look at financial development through banks and also through the stock market. They find that stock market liquidity - this is the ratio of the total value of shares traded to market capitalization - is positively related to growth.

Pesaran and Smith (1995) have suggested that panel data techniques with averaged data may still suffer from econometric problems. Past studies have sometimes averaged data over a few years to remove business-cycle influences. This may cause the loss of information on longrun relationships. It has been suggested (Demetriades and Andrinova, 2003) that increasing data samples to forty or fifty years would make evidence from time-series utilizing techniques more conclusive, especially if the data is available in quarterly frequencies. It must be recognized, however, that in studies that involve many countries, the lack of data availability is always an 
important consideration. Developed countries usually have better data availability when compared to developing countries - since this is a developing country study; data restrictions are of prime concern. Ultimately, while there is a dearth of papers that have looked at the relationship between financial development and growth from various angles, including using different indicators for financial development, different time periods, and groups of different countries, data that spans longer time periods becomes essential to make more conclusive statements on the exact nature of the relationship.

\section{II) Proxies of Financial Development}

Chen and Fische (1993) have discussed a theoretical reasoning that suggests that currency outside the banking system may be a good inverse proxy for financial development in developing countries. They note that deposit insurance schemes do not have a very important role in developing countries which have less diversified economic bases. Depositors thus tend to shy away from the banking system. The result is that alternate informal arrangements such as savings clubs and rotating credit associations become more important in bridging the gap between the borrower and the lender. This argument provides a further theoretical basis for the choice of currency outside the banking system as an inverse proxy for financial development. The more developed a financial system, the greater the role that deposit insurance plays in the banking system, and thus the greater the amount of money within the banking system.

Moreover, real interest rates in developing countries are on average, negative. This in essence, defines developing countries as financial repressed economies. Standard money demand models such as the Baumol-Tobin approach indicate that money holdings are inversely related to real interest rates. Therefore if real interest rates are negative, this would indicate a low level of deposits. Financial repression, which is indicative of low financial development, is then characterized by a low ratio of deposits. Thus private sector funds are not in the banking system but outside of it. The higher the level of currency outside the banking system (given a financially repressed economy), the lower the level of financial development, and the more restricted the access to those funds by investment projects. This compromises the link between investment and economic growth. Thus a high ratio of currency outside the banking system should be negatively related to economic growth.

The logic behind using currency outside the banking system relative to real output as a proxy for financial development is as follows: as a country begins to develop its financial sector, the banking system develops first as an initial bridge between savers and borrowers. If there is a large amount of money outside the banking system, this would indicate that the banking sector is compromised (perhaps through financial repression) and savers do not have access to varied instruments through the banking sector. Thus a large amount of money outside the banking sector would seem to be an indicator of a lower level of financial development. Most developing countries began the process of financial development within the last three decades. More evolved methods of linkage between savers and borrowers such as mutual funds or stock markets are relatively recent introductions into these countries.

At an intermediate level of financial sector development, CB may actually fall as savers explore increased options within the banking sector and firms flock to the banks for their financing needs. However, as the level of financial sector development increases further, CB (and also deposits within the banking sector) may actually rise again as the development of institutions such as mutual funds and stock markets develop. This is a proxy that can reflect the development of a financial sector given the removal of the elements of financial repression. In countries in the initial stages of financial sector liberalization, the ratio is expected to be high, and negatively related to growth. As countries reach the intermediate stage, the ratio is expected to fall, and then as countries reach the more advanced stages of financial sector development, the 
ratio is expected to rise again. It must be noted of course, that financial sector development here is relative since the sample consists entirely of developing countries. In the intermediate and higher growth countries, $\mathrm{CB}$ is expected to become positively related to growth. Overall CB essentially fulfills the requirements of being a measure of financial development that can capture the degree of financial development in all its changing aspects.

The use of $\mathrm{CB}$ as a ratio of financial development begs the use of the opposite of $\mathrm{CB}$ deposits within the banking sector over gdp (henceforth referred to as DGDP) as another proxy. The results are expected to indicate the opposite relationship (when compared with $\mathrm{CB}$ ) - a positive relationship with economic growth.

An interesting criticism of the CB proxy arises due to the concept of dollarization, which is popular in developing countries with weak macroeconomic systems, and weak local currencies. Dollarization occurs when the residents of a country use a dominant foreign currency in parallel with the local currency unit (LCU). Contrary to what the name of the phenomenon suggests, dollarization does not necessarily mean the use of only the US dollar - currently the Euro, the Australian dollar and the Danish kronor are being used as parallel currencies. Dollarization could occur in three main ways - it could occur unofficially, it could occur in a bimonetary system, where the foreign currency is legal but a secondary currency to the LCU, and it could also occur where a country officially abandons the use of its LCU in favour of the foreign currency.

Dollarization occurs because residents of a country are seeking stability which cannot be found in the LCU. Due to excessive seigniorage or discretionary monetary policy, there may be excessive inflation, and the LCU may devalue excessively. High and unstable inflation rates lead to a lower level of investment and ultimately lower economic growth. The loss of value of the LCU leads to a substitution into the foreign currency unit. Opponents of dollarization mention that excessive dollarization leads to a lack of control for domestic monetary policy.

Most of the Latin American and African countries in the sample have experienced excessive dollarization at some point, and in most cases, the dollar or the currency of the former colonial power (in the case of a few African countries) continues to be a major unofficial force. $\mathrm{CB}$ is thus not immune to the effects of dollarization. Excessive dollarization involves residents substituting into the foreign currency - CB will thus rise as individual transfer local currency units into dollars and other strong foreign currencies. Conversely in periods of local currency stability, residents regain faith in the local currency and $\mathrm{CB}$ will fall. Thus a high $\mathrm{CB}$ level may be expected during periods of high dollarization. This may of course lead to the use of the proxy to indicate periods of excessive dollarization.

Official dollarization is empirically easier to examine than unofficial dollarization, and so $\mathrm{CB}$ is examined in the case of two official dollarization periods for Argentina where President Carlos Menem declared official dollarization (based on the US dollar) in 1999. A priori it is expected that Argentina's CB ratio would increase as there is excessive substitution into the US dollar. The graphs of the behaviour of $\mathrm{CB}$ (and the innovative approach to measuring financial repression, FR) in Argentina over time are presented in the appendix.

Monetary depth measures have been used several times in past studies as representative of the formal size of the financial sector in an economy. Goldsmith (1969) discussed the nature of the financial sector in developing countries. Firms in developing countries resort to greater levels of self-finance than firms in developed countries. When financial instruments are issued by firms, they are primarily procured by financial institutions rather than private savers. There are few large "organized" markets for the trade of securities such as bonds, mortgages, and stocks, mostly because such markets require economies of scale that are generally not present in developing countries. There is thus limited direct contact between the savers and the borrowers and instead indirect interaction through the monetary mechanism, which is the lifeline of the financial sector. It therefore becomes reasonable to develop theoretical models where money (defined to include all deposits in the banking sector, as well as currency) is the only financial asset available to savers. (McKinnon, 1973) 
Uncertainties regarding risk and return are acute in developing countries and money becomes the asset that is most risk-free and default-free for short-term transactions. Since lenders do not have access to sophisticated methods of risk-analysis (available in developed countries), financial instruments other than money cannot be well marketed. Hence money becomes the choice instrument of private capital. (McKinnon, 1973)

\section{I) Methodology}

Three proxies of financial development are used in this paper - CB, DGDP, and M - the choice of these measures is based on what makes logical and theoretical sense from a developing country perspective. Lack of continuous data series for developing countries limits the sample size to 32 countries. 1995 is the base year for the consumer price index data for all thirty-two countries. Raw data is transformed into the required variables of interest as follows: economic growth is calculated as the percentage change in gdp per capita; inflation is calculated as the percentage change in the consumer price index. Real interest rates are calculated using the Fisher Identity, and are the difference between the nominal rate of return on 3-6 month deposits at banks and the inflation rate. Currency outside the banking system (CB) is calculated as the ratio of currency outside domestic banks to nominal gdp. Banking sector deposits (DGDP) is calculated as the ratio of total deposits (including checking, time and savings deposits) in the banking sector to nominal gdp. Monetary depth (M) is the ratio of broad money (M2) to nominal gdp. All the data is procured from the World Bank's World Development Indicators, and the IMF's International Financial Statistics.

For the purposes of this study, M provides the standard against which other proxies are tested. Greater broad money or narrow money depth indicates greater financial deepening, and a greater size of the formal financial sector, and thus represents greater financial development. As mentioned though, these measures are prone to criticism, hence the search for more theoretically sound proxies is a worthwhile cause.

This paper proposes a new measure for financial repression that actually combines both two proxies of financial development - CB and DGDP, and creates a new variable called FR (CB/DGDP). It is proposed that the ratio of currency outside banks to currency inside banks can best proxy for financial repression. If this ratio is low, then it could reflect a banking sector where savings and lending are allotted according to market forces. This ratio would be low only if there was a marked absence of real interest rate ceilings and directed lending. This proxy is especially important for countries where there is considerable government interference in the banking sector, that is, in less liberalized countries. For example, most of the Sub-Saharan African countries still have banking sectors that are less developed than those of Asian countries, and where government still have interest rate ceilings in place. In South East Asian countries, in comparison, where financial sector liberalization has been underway for almost two decades, financial repression is less of an issue. 


\section{II) The following broad null hypotheses are tested in this paper:}

I. In the lower growth countries (the African group of countries) that have less developed financial sectors, the CB ratio is expected to be high (this follows from Goldsmith's (1969) findings). In the intermediate group of countries (the Latin American set) the ratio is expected to be lower than the African set, and in the more financially liberalized group of countries (the South East Asian set) CB is expected to rise again. Thus the null hypothesis is the CB should display a U-shaped behaviour in relation to the level of economic development and financial sector liberalization.

II. In relation to using $\mathrm{CB}$ as a proxy for financial development, it is expected that a high currency outside the banking system to real gdp ratio will have a negative relationship with economic growth, especially in countries that are in the early sample of financial sector liberalization. The null hypothesis is then that CB should be negatively related to growth for the less liberalized group of countries, that is, the African sample of countries.

III. It follows that DGDP should be inversely correlated with CB, and thus DGDP should have a positive relationship with economic growth. The null hypothesis here is that DGDP should be positively correlated with growth in all the sample countries. The reasoning here is that even when an economy is more financially liberalized, the banking sector is still important in growth as it forms the allocative bridge between savings and growth projects.

IV. It is expected that a larger formal financial sector should be positively related to growth, but with a caveat. The $\mathrm{M}$ variable proxies for the size of the formal financial sector, and its relationship with economic growth is expected to be positive, but only if a dummy variable for money growth is included. This effectively controls for the effects of seigniorage, which has been common in developing countries. The null hypothesis here states that the relationship between $\mathrm{M}$ and economic growth should be positive when excess money growth is controlled for.

V. $\quad \mathrm{RI}$ is expected to be higher (in negative values) for the African set of countries and display positive or higher positive values for the other two geographical groupings.

VI. In relation to the unique new measure of financial repression, FR, the ratio is expected to be higher in value in the African sample of countries as opposed to the other two groups, as financial repression has been higher in this set. 
Table 1: Behaviour of Financial Development Proxies Over Time for the Different Regions (Mean Values Over Time)

\begin{tabular}{|c|c|c|c|c|c|}
\hline $\begin{array}{c}\text { Period 1970- } \\
1980\end{array}$ & $C B^{*}$ & $M^{*}$ & $D G D P^{*}$ & $R I^{* *}$ & $F R^{*}$ \\
\hline Full sample & 0.489 & 21.991 & 0.186 & -8.133 & 3.979 \\
\hline Africa & 0.477 & 21.202 & 0.171 & -5.917 & 4.849 \\
\hline Latin America & 0.402 & 18.946 & 0.199 & -23.841 & 2.367 \\
\hline South-East Asia & 0.601 & 26.745 & 0.219 & -0.678 & 2.995 \\
\hline $\begin{array}{c}\text { Period 1981- } \\
1990\end{array}$ & $C B *$ & $M^{*}$ & $D G D P^{*}$ & $R I^{* *}$ & $F R^{*}$ \\
\hline Full sample & 0.496 & 28.894 & 0.236 & 3.145 & 3.225 \\
\hline Africa & 0.503 & 27.581 & 0.207 & -7.803 & 4.148 \\
\hline Latin America & 0.388 & 23.219 & 0.222 & 40.824 & 1.956 \\
\hline South-East Asia & 0.569 & 37.319 & 0.326 & 4.216 & 1.806 \\
\hline $\begin{array}{c}\text { Period 1991- } \\
2002\end{array}$ & $C B^{*}$ & $M^{*}$ & $D G D P^{*}$ & $R I^{* *}$ & $F R^{*}$ \\
\hline Full sample & 0.475 & 32.256 & 0.269 & -1.762 & 3.104 \\
\hline Africa & 0.468 & 26.889 & 0.214 & -3.849 & 4.089 \\
\hline Latin America & 0.368 & 24.486 & 0.223 & 0.048 & 1.948 \\
\hline South-East Asia & 0.589 & 52.032 & 0.458 & 2.477 & 1.423 \\
\hline \multicolumn{6}{|c|}{$\begin{array}{l}* \text { Nominal values } * * \text { Real values } \\
* * * \text { All entries are mean values over sample countries. }\end{array}$} \\
\hline
\end{tabular}

In Table 1 above, $\mathrm{CB}$ is the ratio of currency outside the banking system to GDP, $\mathrm{M}$ is the ratio of M2 to GDP, DGDP is the ratio of banking sector deposits to GDP, RINT is the real interest rate (calculated as per the Fisher Identity), and FR is CB/DGDP. Table 1 above clearly supports null hypothesis 1 - the $\mathrm{CB}$ ratios display the $\mathrm{U}$-shaped characteristic in relation to the level of financial sector development. In the African and South East Asian group of countries, the CB values are consistently higher than those in the Latin American group. Hypothesis 1 is then accepted in this particular 33-country sample set. 


\section{Table 2: Summary Statistics for all proxies (FD and financial repression) for full sample and regions}

\begin{tabular}{|c|c|c|c|c|c|}
\hline $\begin{array}{c}\text { Period 1970- } \\
\text { 2002 }\end{array}$ & $\boldsymbol{C B}$ & $\boldsymbol{M}^{*}$ & $\boldsymbol{D G D P}$ & $\boldsymbol{R} \boldsymbol{I}^{* *}$ & $\boldsymbol{F R}^{*}$ \\
\hline Full sample & 0.486 & 27.815 & 0.231 & -2.398 & 3.432 \\
\hline Africa & 0.481 & 25.221 & 0.197 & -5.737 & 4.361 \\
\hline Latin America & 0.385 & 22.391 & 0.215 & 4.441 & 2.090 \\
\hline South-East Asia & 0.587 & 39.508 & 0.338 & 1.907 & 2.063 \\
\hline *Nominal values & **Real values & & & \\
\hline
\end{tabular}

The above descriptive statistics in Table 2 reveal some interesting facts about the relationship between financial development and financial repression. When the descriptive statistics are calculated by region, it is evident that the overall sample statistics conceal significant differences between the regions. The overall sample is heavily weighted towards the African countries, which are greater in number in the sample than the countries from the two other regions. The African sample is close to the average $\mathrm{CB}$ value for the full sample. South East Asia on the other hand, has a higher CB ratio than the full sample average. This is not surprising because the average South East Asian country is more financially liberalized (in terms of the availability of non-bank financial instruments and a longer existence of fully functioning stock markets) than the countries in, for example, the African sample. For the full period 1970-2002, the $\mathrm{CB}$ values again display the U-shaped behaviour that was displayed in Table 1.

Within the banking sector, South East Asian countries also have higher ratios of DGDP reflecting not only a greater degree of economic growth (thus a greater savings ratio), but also a greater degree of saver faith and financial return in the banking sector due to less financial repression. The overall sample's statistics indicate that on average, the African group of countries is financially repressed (reflected by negative RI). As the analysis proceeds to the Latin American and South East Asian groups of countries, the RI values on average become positive. The evidence then suggests that null hypothesis 5 is accepted.

The new FR variable highlights the degree of financial repression even more starkly. The degree of financial repression (as measured by FR) is more than twice that of both the Latin American and the South East Asian sample. This indicates that a very high degree of money is outside the banking sector in the African sample. In these countries, that have a lesser degree of financial development, the non-bank financial sector is rather under-developed and there are not many alternative instruments such as mutual funds or long-standing and fully functioning stock markets. Thus savers shy way from the banking sector, not only due to low economic growth (which causes a low savings rate), but also due to depressed real interest rates (as evidenced by the average negative real interest rates in the African sample). Overall then, the FR values behave as expected and on average, fall as finance become more liberalized - this evidence supports null hypothesis 6 . 
It is interesting to consider the relationship between the proxies themselves, and also with investment. This relationship is not a priori clear-cut. CB could be expected to be inversely correlated with DGDP, since the higher the level of currency outside the banking sector, the lower the level of currency inside the banking sector. However, in a case where an economy is highly developed, a high level of CB could go hand in hand with an increased level of DGDP because both bank and non-bank sectors offer a multitude of options for savers. CB is expected to be positively correlated with $\mathrm{M}$, because $\mathrm{CB}$ is in effect part of $\mathrm{M}$. The proxies are expected to be positively correlated with investment due to the capital accumulation theory. Table 3 shows the averaged cross-sectional correlations between financial development and investment for the entire sample period T. As expected all the proxies are positively correlated with INV; DGDP shows the strongest correlation due to the fact that investment directly depends on the amount of deposits available for investors to borrow. The correlation between CB and DGDP is positive, possibly reflecting a greater weight from those economies further along the development spectrum. It must be noted though that since if money growth is positive, then both $\mathrm{CB}$ and DGDP are expected to display positive growth as well, and the positive correlation may be displaying the growth of both measures.

Table 3: Correlation Between FD Proxies, FR and Investment

\begin{tabular}{|c|c|c|c|c|c|}
\hline & $\boldsymbol{C B}$ & $M$ & $D G D P$ & FR & INV \\
\hline$C B$ & 1.0000 & $\begin{array}{c}0.344656 \\
(0.451167) *\end{array}$ & $\begin{array}{c}0.164884 \\
(0.455132) *\end{array}$ & $*$ & $\begin{array}{c}0.010128 \\
(0.441612)^{*}\end{array}$ \\
\hline$M$ & & 1.0000 & $\begin{array}{c}0.708602 \\
(0.354261) *\end{array}$ & $\begin{array}{c}-0.37024 \\
(0.463497) *\end{array}$ & $\begin{array}{c}0.196427 \\
(0.391622) *\end{array}$ \\
\hline$D G D P$ & & & 1.0000 & * & $\begin{array}{c}0.209362 \\
(0.325124) *\end{array}$ \\
\hline$F R$ & & & & 1.0000 & $\begin{array}{c}-0.16926 \\
(0.410229)^{*}\end{array}$ \\
\hline$I N V$ & & & & & 1.0000 \\
\hline \multicolumn{6}{|c|}{ *Correlations are not performed between FR, CB and DGDP since CB and DGDP are components of FR. } \\
\hline \multicolumn{6}{|c|}{ **Standard deviations in parentheses } \\
\hline \multicolumn{6}{|c|}{ Correlations taken over the full sample 1970-2002 for all countries in the total sample } \\
\hline
\end{tabular}




\section{III) The Model}

Using OLS on pool data has been shown in the literature to be a good way to get first pass point estimates. Phillips and Moon (1999) and Pedroni (2000) have shown that OLS estimators are consistent with pool data. As $\mathrm{N}$ (the number of cross-sectional units) increases, however, the residual asymptotic bias increases.

The standard approach in the literature is to use a panel regression of the form:

$$
X_{i t}=\alpha F D_{i t}+\beta Z_{i t}+\mu_{i t}
$$

$\mathrm{X}$ represents the growth of per capita real GDP (this factor could also be a measure of the total factor productivity growth) in country $i$ at time $t$. The set of FD contains variables that represent financial development. This set comprises of CB, DGDP and M.

$\mathrm{Z}$ is a vector of conditioning variables, and usually includes other factors that theoretically affect economic growth. One of the factors in the set of $\mathrm{Z}$ may be the $\log$ of initial real GDP per capita. This factor measures the convergence effect. The literature has included such variables as the log of initial higher education enrollment as a measure of human capital, and the population growth rate. Other factors that are sometimes included here include the inflation rate, an export and import to real GDP ratio factor (to measure openness), etc. In the case of this paper, the set of $Z$ is restricted to first four and then five variables - the log of initial lagged GDP per capita, GDP(-1), the degree of openness of the economy, OPEN, a measure of inflation, INF, a measure of real interest rates, RI, and a dummy variable for excess money growth, DM. GDP(1) measures the convergence effect over time. OPEN (measured as the sum of foreign direct investment (FDI) and total credit from foreign sources $^{8}$ ) indicates that the more open an economy, the greater the degree of economic development is expected to be, because the greater the potential for technology transfer and technology mimicry. As mentioned earlier, decreased openness is consistent with financial repression whereby domestic agents are restricted from foreign borrowing and lending. A greater degree of openness is therefore indicative of a lesser degree of financial repression. INF is the percentage change in the annual GDP deflator, and DM is set to capture excess money growth of over $10 \%$ per annum.

A priori, the null hypothesis is for $\alpha$ (the coefficient on financial development) is expected to differ depending on the proxy being used for financial development. When FD is restricted to $\mathrm{CB}$, the null hypothesis for the overall sample is that $\alpha$ will be negatively and significantly related to growth (following the Chen-Fisch (1993) paper). However this null hypothesis only holds with reference to the overall sample. (A discussion on what $\alpha$ is expected to be for the different geographical regions follows shortly.) When the FD vector is restricted to include $\mathrm{M}$ alone, the coefficient on $\alpha$ is expected to be positive for the overall sample and all sub-samples (following the implications of the King and Levine papers). Finally, when the FD vector is restricted to include DGDP alone, the coefficient on $\alpha$ is expected to be positive for the overall sample and all subs-samples.

In this paper, the basic methodology is transformed to include a financial repression variable, and a set of financial development variables as well as the vector of $\mathrm{Z}$ variables. Equation (1) is then transformed to equation (2) below.

$$
X_{i t}=\delta F R_{i t}+\alpha F D_{i t}+\beta Z_{i t}+\mu_{i t}
$$

\footnotetext{
${ }^{8}$ Sum of lines 78bed and 78bid from the IMF's International Financial Statistics.
} 
A priori, in equation 2 above, the $\delta$ variable is expected to differ in value depending on the sample being tested (the null hypotheses for $\delta$ for the sub-samples are discussed shortly). For the overall sample, the coefficient on $\delta$ is expected to be negative and significant following the theoretical implications described in section 3A. The null hypotheses for $\alpha$ are as described for equation 1.

Several regression results are presented. First a broad regression (equation 1) for the entire sample period is examined to test for the overall relationship between finance and growth; financial repression is measured by RI. Thereafter, the regression is re-run for different geographical regions - Africa, Latin America and South-East Asia for the full sample period. Equation 2, where FD is measured by $\mathrm{M}$ and financial repression is measured by FR is then run on the broad sample and all the sub-samples.

For robustness purposes, a dummy variable is created for excess money growth (above $10 \%$ per year) in all the thirty-three countries. The sample is thus split again to test the broad regression (including the dummy for money growth) for the different geographical areas. The regional grouping also serves to split countries according to according to whether they classify as "financially repressed" or "financially liberalized". This classification based on real interest rates is due to Pill and Pradhan (1997). On average the African countries exhibit the greatest degree of financial repression. For further robustness checks, the time period is split into three decades to judge whether the relationship differs according to periods of greater reform or not. The sample is also split into two periods - pre- and post oil crisis - to see whether the relationship changes due to the effect of a supply-side shock.

\section{Results}

Table 4 (Appendix 2) presents the results of eight regressions on the entire sample period, 1970-2002, for the different groups of developing countries, with and without the DM variable. The proxy of choice in table 2 is the $\mathrm{CB}$ variable. The null hypothesis in regression 1 is that $\mathrm{CB}$ will be negatively related to growth. When the regression is run for all 32 countries (equation 1), the ratio of currency outside the banking system to gdp is significantly negative. The null hypothesis is accepted. Theory suggests (as discussed earlier) that this is indicative of a poorly developed financial system, which then translates into a poor link between savers and borrowers, and thus decreased efficiency in the savings-investment link, leading to lower real output.

However, as discussed earlier, overall results are not indicative of differences in the different geographical regions. Therefore the regression is then performed for the different country groupings. The statistical behaviour of the CB ratio (as shown earlier) is that it displays a Ushape. The coefficient on $\mathrm{CB}$ is significant and negatively related to growth in equation 2 , the sample of African countries, (as expected), again reflecting the poor state of financial sector development in these countries. The null hypothesis is again accepted here. In the Latin American regression (equation 3), the variable is not significant, although it is a negative coefficient. The null hypothesis thus cannot be accepted in the Latin American sample. SouthEast Asia (equation 4) has higher growth rates than the rest of the developing countries in this sample, and thus it is not surprising that the ratio is significantly (at the $5 \%$ level) positively related to growth in this region (reflecting the right hand end of the $\mathrm{U}$ ). The South-East Asian countries have financial systems that are better developed and offer a more diverse array of financial instruments outside the banking sector to savers, and firms. The null hypothesis in equation 4 is that $\mathrm{CB}$ will be significantly positively related to growth, and the results for equation 4 show that $\mathrm{CB}$ is indeed positively and significantly related to growth here and thus the null hypothesis is accepted here. 
Overall, the results indicate that the CB proxy does indeed fulfill the function of a measure of financial development that can capture the changing nature of the financial sector as a result of liberalization. The empirical evidence in Table 4 indicates that broad null hypothesis II (referred to in section 3B) is accepted.

With reference to the RI variable, it is expected that only in the countries that are financially repressed will the variable turn out to be significantly related to growth. The null hypothesis then states that RI will be negatively related to growth in the African sample only. As expected, only in African countries is the financial repression variable (RI) shown to negatively impact growth. The coefficient on this variable is negative and significant in this sample of countries. African countries have long experienced financial repression, which usually has been part of political repression, and it is only recently that some African countries have begun the process of liberalization of finance and trade. This finding echoes previous findings in the literature that indicate the excessive regulations and distortions in the financial market negatively impact the savings-investment link and thus negatively impact growth.

When the regressions are run with the dummy variable for excessive money growth included (Table 4 - equation $1 b, 2 b, 3 b$ and $4 b$ ), the results show that excessive money growth negatively affects economic growth (without entering into the well-known and ongoing discussion about the causality between money and output). Indeed, the DM variable shows a significantly negative coefficient for all the samples (it is very close to the significance level for the South-East Asian countries), except for Latin America. In the Latin American sample, surprisingly, it very clearly shows a positive relationship. In Latin America, excess money growth seems to positively affect output. Further discussion on the effects of money growth on output differences is left for another study as the discussion best fits the money-output literature.

Theory predicts that the larger the monetary depth measure, the larger the size of the formal financial system, and thus the higher the rate of economic growth. Since M2 contains more developed savings instruments such as money market mutual funds and time deposits, it would indicate that there are other options for savers besides the basic checking and savings deposits. Mutual funds and time deposits may be offered by institutions other than the banking system and thus a high monetary depth ratio may exist simultaneously with a high currency outside the banking system ratio. Table 5 (Appendix 2) shows the results of the regression with the variable in the FD vector being $M$ representing the size of the financial sector. When the regression is run for all countries in the sample together, the results indicate a strongly significant positive relationship between $\mathrm{M}$ and growth. The null hypothesis that $\mathrm{M}$ will strongly positively impact growth is accepted here. The results are less clear, however, when the region-specific results are analyzed. In the African group, the coefficient is both positive and insignificant, indicating that financial depth is not important in explaining growth. In the Latin American and South East Asian groups, the coefficient is negative in sign, but insignificant. In equations 2,3 and 4 therefore, the null hypothesis that the formal size of the financial sector positively affects growth cannot be accepted.

Table 5 also displays the results for the same regression discussed above, but with the dummy for money growth included (equations $1 b, 2 b, 3 b$, and $4 b$ ). The results are robust to the inclusion of the dummy - money does not seem to significantly relate to growth in all sub-sets of the samples. The results mirror those of Table 4, in that excessive money growth is shown to negatively impact economic growth in all the samples, except the Latin American group. The Latin American countries thus present something of a paradox - monetary depth seems to negatively affect growth, although the effect is very small, while excess money growth positively affects growth. Overall the evidence does not support hypothesis 4.

In Table 6 (Appendix 2), the basic model's FD vector in restricted to include the third proxy for financial development, DGDP. Theory suggests that DGDP should have a positive correlation with growth. The null hypothesis is then that DGDP will positively impact growth in the overall sample and all sub-samples. The overall regression presents a very strong positive 
correlation between DGDP and growth (the null is accepted here). On closer observation with the region-specific regressions, it becomes evident that this relationship is not uniform across all regional groupings. The relationship is strongly positive in the African group of countries, although the significance is lost when the dummy for excessive money growth is included. The savings-investment link is a more developed one in South East Asia and so the coefficient presents the expected positive value.

In the Latin American group of countries, the proxy displays an insignificant negative relationship. The null hypothesis is very significantly rejected here. A possible explanation could be related to the politico-economic and currency fluctuations within Latin America that has led to a preference for non-local currency based assets outside the banking sector (DeGregorio and Guidotti (1995) refer to the "extreme experiments of financial liberalization" in Latin America during the 1970s and 1980s, which then subsequently caused economic collapses). Regardless of the proxy for financial development being used, the dummy variable for excessive money growth consistently reflects a negative relationship between excess money growth and economic growth, except in Latin America. The Latin American group of countries therefore continues to display results that are diametrically opposite to those in the other regional splits.

Table 7 (Appendix 2) presents the results for the innovative approach where FR measures financial repression (as opposed to a more traditional measure where real interest rates proxy for financial repression). The FR variable is run simultaneously with the monetary depth variable $\mathrm{M}$, which is used as a standard measure of the size of the formal financial sector. Recalling earlier findings, the FR ratio progressively decreased with financial liberalization. The null hypothesis for equations $1,1 b, 2$ and $2 b$ is that FR will be significantly and negatively related to growth.

The results strongly support the use of FR as a measure of financial repression, and justify the importance of controlling for financial repression as well as financial development when looking at the effect of finance on growth. FR turns out to be strongly negative in the overall regression, and moreover it is also strongly negative in the African sample of countries, which is more financially repressed than the other groups. The results are also robust to the inclusion of the dummy variable for excess money growth. In equations $3,3 b, 4$, and $4 b$ the null hypothesis changes and it is expected that FR will be positively and significantly related to growth. However, the evidence for this null hypothesis is not strong. In both the other two groups of countries, as expected (because they are more financially liberalized than Africa), the coefficient turns out to have a positive (albeit insignificant) relationship with growth. In this group of counties, there are better-developed savings channels outside the banking sector, and so the ratio of CB to DGDP would be lower. This is then consistent with the results from the regression analysis. Overall the evidence supports broad hypothesis VII (referred to in section 3B).

\section{I) Robustness Tests}

To check if the results using FR are robust, the basic regression (with FR measuring financial repression, and $\mathrm{M}$ measuring financial development) is run for the overall sample and for the three geographical regions for three different time periods; 1970-1980,1981-1990, and 1991-2002. While Latin American and South-East Asian countries were already involved in financial reform in the 1980s (although as mentioned, the Latin American policies were more volatile in nature), most of the Sub-Saharan countries began financial reforms under the IMF's Structural Adjustment Programs during the late 1980s and 1990s. At this point, it is doubtful whether enough time series data is available to display a positive relationship between $M$ and economic growth in the African sample of countries. The effects of financial sector liberalization are long-term and the relationship is expected to turn positive with time, and given consistent economic and financial sector development. 
If the FR variable is a robust indicator of financial repression, it should display more strongly negative results for the African sub-sample for 1970-1990, and less strongly negative thereafter. Table 8 shows the results for the $1970-80$ period. FR is very strongly negative for the overall sample. Interestingly $\mathrm{M}$ is negatively related (but not significantly) to growth in the overall sample, regardless of whether the dummy for excess money growth or not. The results for the African sample display, as expected that FR is very strongly negatively related to growth. The results for the Latin American and Asian groups shows that FR and M are not significant in explaining growth, although the signs are as expected. Table 9 shows the results for the same eight regressions but for the 1980-90 decade. Surprisingly the results show that FR is not significant for the overall sample and for all sub-samples, regardless of whether DM is included or not. In the final 1990-2002 decade (Table 10 in Appendix 2), FR again turns out to be significantly negatively related to growth in both the overall and African samples. Though the results for the FR variable are not robust to the 1980-90 decade, their saving grace is that they seem to indicate that with financial liberalization, the ratio begins to relate less negatively to growth (as evidenced by the overall sample and African sample results over the three decades). There is thus only weak support for the hypothesis that FR should relate less negatively with growth as the process of liberalization continues.

Also for robustness purposes, the sample period was split into two pre and post oil shocks, to see whether the results change due to the effects of a supply-side shock. A supply shock of the magnitude of the oil crisis is expected to disrupt the liberalization process due to the massive capital outflow in response to high oil prices. In an economy with a low level of financial development, the result of a supply-side shock is a compromised banking sector unable to meet the demands of funds dependent on oil, and a high level of inflation that causes a greater degree of financial repression as real interest fall drastically. Financial repression causes a greater reluctance by economic agents to save within the banking sector, and currency looks for other opportunities outside the banking sector.

Tables 11 and 12 in Appendix 2 present the results for the regressions pre and post oil shocks. The results show that the specification is robust to a supply side shock. The strongest results are displayed for the entire sample and the Sub-Saharan African sample, even when the dummy variable for excess money growth is included. As previously discussed, financial development does not seem to be important in explaining Latin American growth.

\section{II) Causality Tests}

Past studies have been unable to concretely determine whether in fact, there is a financial development and growth, and if so, in what direction. This paper has shown that a relationship does indeed exist. This paper now discusses the causality issue using CB. M, DGDP and FR. Recent theoretical advancements have allowed for the use of the Granger causality tests using panel data (Hurlin and Venet, 2004). In a bivariate setting, the first variable is found to Grangercause the second variable if the forecast for the latter improves when the regression includes lagged values of the former (Granger, 1969). In the absence of long time series information, panel data allows the use of both cross-sectional and time series data and thus effectively increases the degrees of freedom. There is thus a marked improvement in the effectiveness of Granger causality tests.

Table 13 (Panels A and B) present the results of the HV Granger causality test on the panel set for the period 1970 to 2002 . 
Table 13

Causality from Economic Growth to Financial Development 1970-2002

\begin{tabular}{|c|c|c|c|}
\hline \multicolumn{2}{|c|}{ PANELA } & \multicolumn{2}{|c|}{ PANEL B } \\
\hline & $\begin{array}{c}\text { Z HNC } \\
\text { (FULL SAMPLE) }\end{array}$ & & $\begin{array}{c}\text { Z HNC } \\
\text { (FULL SAMPLE) }\end{array}$ \\
\hline$E G T O C B$ & 1.592093 & CB TOEG & 2.401736 \\
\hline EG TO DGDP & 0.67745 & DGDP TO EG & 0.674353 \\
\hline EG TO M & 0.797947 & M TO EG & 1.601507 \\
\hline EG TO FR & 0.14974 & FR to EG & 0.85083 \\
\hline \multicolumn{4}{|c|}{$\mathrm{Z}$ hnc is the $\mathrm{Z}$ statistic (see Appendix 1) for the null hypothesis of homogenous non-causality. } \\
\hline \multicolumn{4}{|c|}{$\begin{array}{l}\text { Overall } \mathrm{Z} \text { converges weakly to a } \mathrm{N}(0,1) \text { as follows: } \tilde{\mathrm{Z}}_{N, T}^{H N C} \underset{N \rightarrow \infty}{\longrightarrow} N(0,1) \text {. Critical value is } \\
1.96 \text { for a } \mathrm{N}(0,1) \text {. }\end{array}$} \\
\hline
\end{tabular}

Interestingly, the results are most clear-cut with the $\mathrm{CB}$ variable as compared to the other two proxies. When the economic growth variable is placed on the right hand side of (1), the null hypothesis states that there is no causality from economic growth to financial development. The results are presented in Table 13 Panel A. In this case, the null hypothesis is clearly rejected. Growth affects finance. Economic growth does cause changes in the level of currency outside the banking sector. It is important to understand the implications of this causality. CB is a variable that reflects the state of financial sector development. Earlier results support the hypothesis that as the state of financial sector liberalization improves, $\mathrm{CB}$ will rise again (the right hand side of the $\mathrm{U})$. Thus as economic growth improves, savings rise and the demand for new and alternate and varied non-bank assets increases. Table 13 Panel B displays the results of the causality test where the dependent variable is now lagged values of CB. The null hypothesis cannot be rejected. CB cannot be shown to cause economic growth. However, these results are not surprising considering the nature of the proxy variable, and the sample weighting. The sample is heavily weighted towards African countries, thus since CB reflects the state of financial sector development and if a compromised financial sector exists in an economy, CB will have a negative relationship with economic growth and will not cause economic growth. The causality tests therefore support the hypothesis that CB is useful in identifying the state of financial development in an economy. 
The other proxies are also Granger tested against economic growth and in these cases, there seems to be bi-directional causality. This finding echoes other studies which have found that finance causes growth while growth also causes finance (for example Demetriades and Hussein, 1996).

Causality tests are also run for FR and economic growth. A priori the expectation is that the homogenous non-causality null hypothesis will be rejected when testing for causality running from economic growth to financial repression. When the HV approach is used, this null hypothesis is, surprisingly rejected, showing causality from economic growth to financial repression. However, this can be explained when one reflects on the alternate approach when the null hypothesis states homogenous non-causality from financial repression to economic growth the null hypothesis is again rejected here. Thus there is bi-directional causality between the FR ratio (CB/DGDP) and economic growth. The bi-directional causality seems to be a result of the nature of the FR variable. While higher ratios of CB and DGDP affect growth, higher economic growth also causes higher CB and DGDP ratios.

\section{Conclusion}

The relationship between finance and growth while theoretically sound, is not unanimously agreed upon empirically. This paper looked at the relationship between financial development and growth while controlling for financial repression and geographical proximity. Currency outside the banking system relative to gdp (CB), broad money relative to gdp (M), and deposits within the banking sector relative to gdp (DGDP) are used as proxies for financial development. CB is a unique proxy in that it explains, to some extent, why there are so many different findings in the literature regarding the relationship between financial development and growth. These findings are very sensitive to the choice of proxy. The standard monetary depth measures may not be adequate in examining this relationship, because seigniorage can cause monetary depth to increase, falsely indicating financial sector development. It is also evident that monetary depth measures can increase in spite of the existence of financial repression, which indicates a paradoxical state of existence for an economy. CB reflects the development of the financial sector given the knowledge of the liberalization of the financial sector and the degree of financial repression. The results show that $\mathrm{CB}$ is related negatively to growth in the less liberalized developing countries and positively in the more liberalized developing countries.

Past studies have attempted to class countries on income levels, but the results in this paper indicate that even within developing countries, geographical (as well as socio-economic) proximity seems to be a factor in whether the relationship between financial development and growth differ. This finding has a very important implication in terms of development strategy. If countries that are close together are financially repressed, financial liberalization may not work to promote growth if the surrounding countries (especially the trading partners) are not financially liberalized as well. For example, land-locked countries rely on their partners with seaports for trade purposes. If the land-locked countries engage in liberalization, both financial and otherwise, but the neighbouring seaport country does not, liberalization may not impact growth significantly. Needless to say, financial development must be part and parcel of a more comprehensive development package that targets all aspects of economic growth.

Finally the choice of proxy is vitally important in determining causality. The literature is not clear in the exact relationship between financial development and growth - it seems evident that the choice of proxy is a critical matter in answering this question. Currency outside the banking sector seems to be the strongest proxy in terms of causality testing out of the three proxies tested, in that it is the only one that does not show bi-directional causality when new Granger causality tests for panel data sets are applied to the sample. Causality test, however, do 
not allow the support of either the demand-following or the supply-leading hypothesis, because the null hypothesis of non-causality cannot be rejected. It is not surprising, however, that the causality issue cannot be answered with the $\mathrm{CB}$ variable because it is in fact an inverse variable that does not cause economic growth if it is higher in degree in financially repressed economies.

The results indicate that it is important to control for financial repression when looking at the relationship between financial development and growth. Traditionally financial repression is measured through the use of real interest rates. An innovative measure of financial repression (FR) combines the use of the ratio of currency outside banks to currency inside banks relative to gdp. In economies where there is a low level of financial sector liberalization, the ratio becomes particularly illuminative. The results show that countries with low levels of FR relative to the average are higher growth economies. In the African sub-sample of countries, FR is significantly negative in relation to economic growth. Surprisingly the results for all the financial development proxies seem to indicate that financial sector development has not been very important in explaining Latin American growth.

Past studies have often found conflicting results in the causality between finance and growth. This study has shown that different regions display different relationships, that reflect differing degrees of financial sector development. Further work needs to be done to identify a more complete measure of financial development. An ideal measure would encompass deregulation of the financial sector, size of the financial sector, and stock market development.

\section{Literature Cited}

Andres, J. , I. Hernando and D. Lopez-Salido, "The Role of the Financial System in the InflationGrowth Link, Banco de Espana - Servicio de Estudios, Working Papers, 1999.

Atje, R. and B. Jovanovic, "Stock Markets and Development", European Economic Review, 1993, vol. 37, issue 2-3, pages 632-640.

Beck, Thorsten and Levine, Ross. "Stock Markets, Banks, and Growth: Panel Evidence." Working paper, Carlson School of Management, University of Minnesota, May 2002.

Chen, L., and R. Fische, "Informal Financial Arrangements and the Stability of Deposit Insurance Schemes in Less Developed Countries", Southern Economic Journal, July 1993; 60(1): 157-68.

Creane, S., R. Goyal, A.M. Mobarak, and R. Sab, "Financial Development and Economic Growth in the Middle East and North Africa", Newsletter of the Economic Research Forum, for the Arab Countries, Iran and Turkey, Volume 10, \# 2, Summer 2003.

Demetriades, P., and S. Andrianova, "Finance and Growth: What We Know and What We Need to Know" (with P. Demetriades), Discussion Papers in Economics No 03/15, University of Leicester, forthcoming in Charles Goodhart (ed.) Financial Development and Economic Growth: The Links, Routledge.

De Gregorio, J., and P. Guidotti, "Financial Development and Economic Growth", World Development, 1995, vol. 23, issue 3, pages 433-448

Demetriades, P. O., and K. A. Hussein (1996). "Does financial development cause economic growth? Time series evidence from 16 countries." Journal of Development Economics, 51: 385409 
Evans, P. "How to estimate growth equations consistently.” Mimeo, Ohio State University, 1995.

Fry, M. J., "Finance and Growth in Pacific Basin Developing Countries", 1996, Hermes,-Niels; Lensink,-Robert, eds. Financial development and economic growth: Theory and experiences from developing countries. Studies in Development Economics, vol. 6. London and New York: Routledge, pp. 138-58

Gelb, A. H., "Financial Policies, Growth, and Efficiency", 1989, Working Papers, The World Bank; Country Economics Department, Policy Research and External Affairs.

Giovanni Alberto, and Martha de Melo, "Government Revenue from Financial Repression", The American Economic Review, Vol. 83, no. 4, September 1993, pp. 953-963.

Goldsmith, R.W., Financial Structure and Development. Yale University Press, New Haven, CT, 1969.

Hurlin, C., and B. Venet, 2004, "Financial Development and Growth: A Re-examination using a Panel Granger Causality Test", working paper.

Kar, M., and E. J. Pentecost (2000): "Financial Development and Economic Growth in Turkey: Further Evidence on the Causality Issue". Loughborough University, Department of Economics, Economic Research Paper No. 00/27.

King, R.G. and Levine R. (1993a). "Finance and Growth: Schumpeter Might Be Right", Quarterly Journal of Economics, 108 (3), 717-737.

King, R.G. and Levine, R. (1993b). "Finance, Entrepreneurship, and Growth: Theory and Evidence", Journal of Monetary Economics, 32 (3), 513-542.

Levine, Ross. (1997). "Financial Development and Economic Growth: Views and Agenda", Journal of Economic Literature, 35, June, 688-726.

Levine, Ross and Zervos, Sara. "Stock Markets, Banks, and Economic Growth." American Economic Review, June 1998, 88(3), pp. 537-58.

Lucas, R.E. (1988) 'On the mechanics of economic development'. Journal of Monetary Economics 22, 3-42.

McKinnon, R.I. Money and Capital in Economic Development, Washington, D.C.: Brookings Institution, 1973.

Patrick, H. (1966), "Financial development and economic growth in underdeveloped countries", Economic Development and Cultural Change, 14, January: 174-189.

Pedroni, P. (2000) "Fully Modified OLS for Heterogeneous Cointegrated Panels" in Nonstationary Panels, Panel Cointegration and Dynamic Panels, Elsevier Science Inc., 15, 93-130. 
Pesaran, H. and R. Smith (1995) : Estimating Long-Run Relationships from Dynamic Heterogeneous Panels, Journal of Econometrics, 68, 79-113.

Phillips, C.B, and H.R. Moon, "Linear Regression Limit Theory for Nonstationary Panel Data", Econometrica, Vol. 67, No. 5, September, 1999, pp.1057-1111.

Pill, Huw and Mahmood Pradhan (1997). "Financial indicators and financial change: A comparison of Africa and Asia". Savings and Development 21 (2) (June).

Roubini, N. and Sala-i-Martin, X. (1992) 'Financial repression and economic growth'. Journal of Development Economics 39, 5-30.

Shaw, E.S. Financial Deepening in Economic Development, New York: Oxford University Press, 1973.

Stern, N., "The Economics of Development: A Survey", Economic Journal, 1989, vol. 99, issue 397, pages 597-685

Wachtel, Paul. (2003). "What Do We Really Know About Growth and Finance" Federal Reserve Bank of Atlanta Economic Review, First Quarter 2003, 33-47. 


\section{Appendix 1: Panel Granger Causality Tests}

The time stationary VAR approach is adapted to a panel data context as follows. For each individual $i$, there are $\mathrm{t}$ time periods, such that

$\forall t \in[1, \mathrm{~T}]$

$y_{i t}=\sum_{k=1}^{p} \gamma^{(k)} y_{i, t-k}+\sum_{k=1}^{p} \beta_{i}^{(k)} x_{i, t-k}+v_{i, t}$

with $p \in \mathrm{N}^{*}$ and $v_{i, t}=\alpha_{i}+\varepsilon_{i, t}$ are i.i.d. $\left(0, \sigma_{\varepsilon}^{2}\right)$. In this case, financial development and the growth rate of per capita gdp are in turn fitted into (1) as LHS variables. Hurlin and Venet assume that $\gamma^{(k)}$ and $\beta_{i}^{(k)}$ are constant $\forall k \in[1, p]$. It is also assumed that $\gamma^{(k)}$ are constant for all individual countries but that $\beta_{i}^{(k)}$ can differ between individual countries. This then is the basic setting for the panel Granger causality test. The next step then involves testing the homogenous non-causality hypothesis, which is given by:

$\mathrm{H}_{0}: \beta_{i}^{(k)}=0 \forall i \in[1, \mathrm{~N}], \forall k \in[1, p]$

$\mathrm{H}_{1}: \exists(i, k) / \beta_{i}^{(k)} \neq 0$

The above null hypothesis states that no causal relationships exist across N. If the alternate hypothesis is accepted, the conclusion of Granger causality can then be made. This procedure, however, requires that variables that enter into the system be stationary.

For all three of the financial development measures, the unit root tests are significant at the $1 \%$ level when the variables are first-differenced. Therefore, the stationary first differenced variables, rather than the original variables, are used to conduct the Granger causality tests.

Hurlin and Venet (2004) (henceforth referred to as HV) present an innovative but simple

approach to a panel Granger causality test. HV use an average statistic denoted as $W_{H N C}^{b}$, which is found as follows:

$W_{H N C}^{b}=(K / N) \sum_{i=1}^{N} W_{i, T}$

where $W_{i, T}$ represents the individual Wald statistics associated with the test of the non-causality hypothesis for the individual country units $i=1, \ldots \mathrm{N}$. The authors show that under the null hypothesis of non-causality, each individual Wald statistic converges to a chi-squared distribution with $K$ degrees of freedom, when $\mathrm{T}$ tends to infinity.

$W_{i, T} \underset{T \rightarrow \infty}{\longrightarrow} \chi^{2}(K) \quad \forall i=1, \ldots \ldots . N$

Using a standard Lindberg-Levy central limit theorem, the average statistic converges in distribution when $\mathrm{T}$ tends to infinity. For a small $\mathrm{T}$ sample however, the distribution of the individual Wald statistic is a $F(K, T-2 K-1)$. In a dynamic model, the $\mathrm{F}$ distribution can always be used as an approximation of the true distribution of the individual Wald statistic for a small $\mathrm{T}$ sample. Based on these approximation, HV suggest an approximated standardized test statistic $\sim$ HNC

$\tilde{\mathrm{Z}}_{N, T}$ for the average Wald statistic $W_{H N C}^{b}$ of the non-causality hypothesis. 


$$
\tilde{\mathrm{Z}}_{N, T}^{H N C}=\frac{\sqrt{N}\left[W_{N, T}^{H N C}-N^{-1} \sum_{i=1}^{N} E\left(W_{i, T}\right)\right]}{\sqrt{N^{-1} \sum_{i=1}^{N} \operatorname{Var}\left(W_{i, T}\right)}}
$$

where the first two moments of the distribution are approximated by

$\frac{1}{N} \sum_{i=1}^{N} E\left(W_{i, T}\right) \cong K * \sum_{i=1}^{N} \frac{\left(T_{i}-2 K-1\right)}{\left(T_{i}-2 K-3\right)}$

and

$\frac{1}{N} \sum_{i=1}^{N} \operatorname{Var}\left(W_{i, T}\right) \cong 2 K * \sum_{i=1}^{N} \frac{\left(T_{i}-2 K-1\right)^{2} *\left(T_{i}-K-3\right)}{\left(T_{i}-2 K-3\right)^{2} *\left(T_{i}-2 K-5\right)}$

Overall $\mathrm{Z}$ converges weakly to a $\mathrm{N}(0,1)$.

$\sim$ HNC

$\mathrm{Z}_{N, T} \underset{N \rightarrow \infty}{\longrightarrow} N(0,1)$

If the value of the test statistic $\tilde{\mathrm{Z}}_{N, T}^{H N C}$ is greater than the normal corresponding critical value for the given degrees of freedom, the homogenous non-causality hypothesis is rejected. 
Appendix 2: Table 4: Financial Development Proxy: CB

\begin{tabular}{|c|c|c|c|c|c|c|c|c|}
\hline \multicolumn{9}{|c|}{ Dependent variable: Growth rate of real GDP per capita (sample period 1970-2002) } \\
\hline & \multicolumn{2}{|c|}{ All Countries } & \multicolumn{2}{|c|}{ Africa } & \multicolumn{2}{|c|}{ Latin America } & \multicolumn{2}{|c|}{ South-East Asia } \\
\hline & Eq. 1 & $E q .1 b$ & Eq. 2 & $E q .2 b$ & Eq. 3 & $E q .3 b$ & $E q .4$ & $E q .4 b$ \\
\hline $\mathrm{C}$ & $\begin{array}{c}2.402840 \\
(4.238417)^{* *}\end{array}$ & $\begin{array}{c}2.497646 \\
(4.433802)^{* *}\end{array}$ & $\begin{array}{c}3.622998 \\
(4.331817)^{* *}\end{array}$ & $\begin{array}{c}3.863590 \\
(4.675011)^{* *}\end{array}$ & $\begin{array}{c}1.487037 \\
(1.201052) \\
\end{array}$ & $\begin{array}{c}1.001298 \\
(0.794060) \\
\end{array}$ & $\begin{array}{c}0.027234 \\
(0.007933) \\
\end{array}$ & $\begin{array}{c}0.639602 \\
(0.185950) \\
\end{array}$ \\
\hline GDP(-1) & $\begin{array}{c}-0.086363 \\
(1.643549) \\
\end{array}$ & $\begin{array}{c}-0.080851 \\
(-1.560567) \\
\end{array}$ & $\begin{array}{c}-0.022127 \\
(-0.243648) \\
\end{array}$ & $\begin{array}{c}-0.020850 \\
(-0.234756) \\
\end{array}$ & $\begin{array}{c}-0.012963 \\
(-0.247563)\end{array}$ & $\begin{array}{c}-0.001267 \\
(-0.023326)\end{array}$ & $\begin{array}{c}0.266323 \\
(0.448897)\end{array}$ & $\begin{array}{c}0.191177 \\
(0.323917)\end{array}$ \\
\hline RI & $\begin{array}{c}0.000694 \\
(1.096119)\end{array}$ & $\begin{array}{c}0.000722 \\
(1.107688)\end{array}$ & $\begin{array}{c}-0.043855 \\
(-1.547698)^{* *}\end{array}$ & $\begin{array}{c}-0.052442 \\
(-1.887966)^{* *}\end{array}$ & $\begin{array}{c}0.000205 \\
(0.570795)\end{array}$ & $\begin{array}{c}0.000164 \\
(0.483735)\end{array}$ & $\begin{array}{c}0.014334 \\
(0.342875)\end{array}$ & $\begin{array}{c}0.036147 \\
(0.873085)\end{array}$ \\
\hline $\mathrm{CB}$ & $\begin{array}{c}-1.316516 \\
(-1.993393)^{* *}\end{array}$ & $\begin{array}{c}-1.076274 \\
(1.677605) \\
\end{array}$ & $\begin{array}{c}-4.060607 \\
(-4.280970) * *\end{array}$ & $\begin{array}{c}-3.478344 \\
(-3.794612)^{* *}\end{array}$ & $\begin{array}{c}-1.077839 \\
(-0.498092) \\
\end{array}$ & $\begin{array}{c}-1.086889 \\
(-0.491527) \\
\end{array}$ & $\begin{array}{c}1.716058 \\
(2.163687)^{* *}\end{array}$ & $\begin{array}{c}1.882106 \\
(2.375579) *\end{array}$ \\
\hline INF & $\begin{array}{c}-0.006364 \\
(-2.135272)^{* *}\end{array}$ & $\begin{array}{c}-0.006512 \\
(2.145754)^{* *}\end{array}$ & $\begin{array}{c}-0.076707 \\
(-2.754965)^{* *}\end{array}$ & $\begin{array}{c}-0.087384 \\
(-3.165435)^{* *}\end{array}$ & $\begin{array}{c}-0.004015 \\
(-2.419554)^{* *}\end{array}$ & $\begin{array}{c}-0.003707 \\
(-2.357813) * *\end{array}$ & $\begin{array}{c}-0.028419 \\
(-0.695895) \\
\end{array}$ & $\begin{array}{c}-0.035490 \\
(-0.895081)\end{array}$ \\
\hline OPEN & $\begin{array}{c}0.232551 \\
(3.629416)^{* *}\end{array}$ & $\begin{array}{c}0.235466 \\
(3.640161)^{* *}\end{array}$ & $\begin{array}{c}0.184302 \\
(2.435591)^{* *}\end{array}$ & $\begin{array}{c}0.190586 \\
(2.526445)^{* *}\end{array}$ & $\begin{array}{c}0.186877 \\
(1.071609) \\
\end{array}$ & $\begin{array}{c}0.193366 \\
(1.089477) \\
\end{array}$ & $\begin{array}{c}0.194032 \\
(0.651251)\end{array}$ & $\begin{array}{c}0.233573 \\
(0.861263) \\
\end{array}$ \\
\hline DM & & $\begin{array}{c}-1.543206 \\
(3.315909) * *\end{array}$ & & $\begin{array}{c}-2.489706 \\
(-3.987366)^{* *}\end{array}$ & & $\begin{array}{c}1.767749 \\
(2.021807) * *\end{array}$ & & $\begin{array}{c}-2.343405 \\
(-2.843786)^{* *}\end{array}$ \\
\hline $\begin{array}{c}\text { Adjusted } \\
\text { R-squared }\end{array}$ & 0.03 & 0.04 & 0.06 & 0.09 & 0.03 & 0.05 & 0.05 & 0.09 \\
\hline \multicolumn{9}{|c|}{ t-statistics in parentheses are White's heteroskedasticity-consistent t-statistics. $* * t$ statistics significant at $1 \% \quad *$ t-statistics significant at $5 \%$} \\
\hline \multicolumn{9}{|c|}{ The dependent variable is the growth rate of real gdp per capita } \\
\hline \multicolumn{9}{|c|}{ GDP(-1) is the initial level of real GDP } \\
\hline \multicolumn{9}{|c|}{ RI is real interest rates calculated according to the Fisher Identity } \\
\hline \multicolumn{9}{|c|}{ CB is the ratio of currency outside the banking sector to gdp (both numerator and denominator are in nominal values) } \\
\hline \multicolumn{9}{|c|}{ INF is the annual rate of increase in the GDP deflator } \\
\hline \multicolumn{9}{|c|}{ OPEN is the sum of lines 78 bed and 78 bid from the IMF's IFS database } \\
\hline \multicolumn{9}{|c|}{ DM is the dummy variable for excess money growth (measured as annual rates of growth of $10 \%$ or more) } \\
\hline \multicolumn{9}{|c|}{ Ho: CB is significantly and negatively related to growth in eqs. $1,1 \mathrm{~b}, 2$, and $2 \mathrm{~b}$. Ho: CB is significantly and positively related to growth in eqs. $3,3 \mathrm{~b}, 4$ and $4 \mathrm{~b}$. } \\
\hline $\begin{array}{l}\text { Ho: } \mathrm{RI} \text { is sign } \\
\text { and } 4 \mathrm{~b} \text {. }\end{array}$ & antly and negativ & & in equations 1 & & 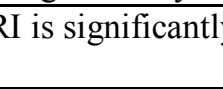 & & & uations $3,3 b, 4$ \\
\hline
\end{tabular}


Appendix 2: Table 5: Financial Development Proxy: M

\begin{tabular}{|c|c|c|c|c|c|c|c|c|}
\hline \multicolumn{9}{|c|}{ Dependent variable: Growth rate of real GDP per capita (sample period 1970-2002) } \\
\hline & \multicolumn{2}{|c|}{ All Countries } & \multicolumn{2}{|c|}{ Africa } & \multicolumn{2}{|c|}{ Latin America } & \multicolumn{2}{|c|}{ South-East Asia } \\
\hline & Eq. 1 & $E q .1 b$ & $E q .2$ & $E q .2 b$ & $E q .3$ & $E q .3 b$ & $E q .4$ & $E q .4 b$ \\
\hline $\mathrm{C}$ & $\begin{array}{c}1.097327 \\
(1.962020)^{*}\end{array}$ & $\begin{array}{c}1.330951 \\
(2.394463)^{* *}\end{array}$ & $\begin{array}{c}2.186075 \\
(2.633742)^{* *}\end{array}$ & $\begin{array}{c}2.762327 \\
(3.376482)^{* *}\end{array}$ & $\begin{array}{c}1.578440 \\
(0.959037)\end{array}$ & $\begin{array}{c}0.857516 \\
(0.522489)\end{array}$ & $\begin{array}{c}-4.471848 \\
(-)\end{array}$ & $\begin{array}{c}-4.086026 \\
(-1.025948)\end{array}$ \\
\hline GDP(-1) & $\begin{array}{c}-0.078761 \\
(-1.447729)\end{array}$ & $\begin{array}{c}-0.073268 \\
(-1.368622)\end{array}$ & $\begin{array}{c}-0.116984 \\
(-1.254001)\end{array}$ & $\begin{array}{c}-0.102150 \\
(-1.128735)\end{array}$ & $\begin{array}{c}-0.017674 \\
(-0.303524)\end{array}$ & $\begin{array}{c}-0.002469 \\
(-0.041562)\end{array}$ & $\begin{array}{c}1.207814 \\
(1.520176)\end{array}$ & $\begin{array}{c}1.186918 \\
(1.659666)\end{array}$ \\
\hline RI & $\begin{array}{c}0.000523 \\
(0.969460)\end{array}$ & $\begin{array}{c}0.000597 \\
(1.004008)\end{array}$ & $\begin{array}{c}-0.027686 \\
(-0.979989)\end{array}$ & $\begin{array}{c}-0.039910 \\
(-1.453725)\end{array}$ & $\begin{array}{c}0.000199 \\
(0.572773)\end{array}$ & $\begin{array}{c}0.000141 \\
(0.436297)\end{array}$ & $\begin{array}{c}0.025053 \\
(0.937132)\end{array}$ & $\begin{array}{l}0.035939 \\
(0.80053) \\
\end{array}$ \\
\hline M & $\begin{array}{c}0.021621 \\
(2.209510)^{* *}\end{array}$ & $\begin{array}{c}0.018553 \\
(2.052905)^{* *}\end{array}$ & $\begin{array}{c}0.001953 \\
(0.174695)\end{array}$ & $\begin{array}{c}-0.000910 \\
(-0.083315)\end{array}$ & $\begin{array}{c}-0.023464 \\
(-0.400281)\end{array}$ & $\begin{array}{c}-0.013700 \\
(-0.234294)\end{array}$ & $\begin{array}{c}0.019234 \\
(0.937132)\end{array}$ & $\begin{array}{c}-0.013934 \\
(-0.654882)\end{array}$ \\
\hline INF & $\begin{array}{c}-0.005397 \\
(-2.083833) * *\end{array}$ & $\begin{array}{c}-0.005818 \\
(-2.095472)^{* *}\end{array}$ & $\begin{array}{c}-0.066813 \\
(-2.398854) * *\end{array}$ & $\begin{array}{c}-0.080594 \\
(-2.929133) * *\end{array}$ & $\begin{array}{c}-0.004138 \\
(-2.410565) * *\end{array}$ & $\begin{array}{c}-0.003711 \\
(-2.306539) * *\end{array}$ & $\begin{array}{c}-0.035703 \\
(-0.793163)\end{array}$ & $\begin{array}{c}-0.039782 \\
(-0.886310)\end{array}$ \\
\hline OPEN & $\begin{array}{c}0.217895 \\
(3.652071)^{* *}\end{array}$ & $\begin{array}{c}0.218359 \\
(3.656869) * *\end{array}$ & $\begin{array}{c}0.235007 \\
(3.013396) * *\end{array}$ & $\begin{array}{c}0.234693 \\
(2.955254) * *\end{array}$ & $\begin{array}{c}0.236599 \\
(1.187606) \\
\end{array}$ & $\begin{array}{c}0.226927 \\
(1.126206)\end{array}$ & $\begin{array}{c}-0.947164 \\
(-1.298190)\end{array}$ & $\begin{array}{c}-0.801312 \\
(-1.157026)\end{array}$ \\
\hline $\mathrm{DM}$ & & $\begin{array}{c}-1.473281 \\
(-3.131815)^{* *}\end{array}$ & & $\begin{array}{c}-2.761851 \\
(-4.263707)^{* *}\end{array}$ & & $\begin{array}{c}1.747466 \\
(1.978409) *\end{array}$ & & $\begin{array}{c}-1.313294 \\
(-1.767505) \\
\end{array}$ \\
\hline $\begin{array}{c}\text { Adjusted } \\
\text { R-squared }\end{array}$ & 0.03 & 0.04 & 0.04 & 0.08 & 0.06 & 0.08 & 0.06 & 0.08 \\
\hline \multicolumn{9}{|c|}{ t-statistics in parentheses are White's heteroskedasticity-consistent t-statistics. $* * t$ statistics significant at $1 \% \quad *$ t-statistics significant at $5 \%$} \\
\hline \multicolumn{9}{|c|}{ The dependent variable is the growth rate of real gdp per capita } \\
\hline \multicolumn{9}{|c|}{ GDP(-1) is the initial level of real GDP } \\
\hline \multicolumn{9}{|c|}{$\mathrm{RI}$ is real interest rates calculated according to the Fisher Identity } \\
\hline \multicolumn{9}{|c|}{$\mathrm{M}$ is the ratio of M2 to gdp (both numerator and denominator are in nominal values) } \\
\hline \multicolumn{9}{|c|}{ INF is the annual rate of increase in the GDP deflator } \\
\hline \multicolumn{9}{|c|}{ OPEN is the sum of lines 78 bed and 78 bid from the IMF's IFS database } \\
\hline \multicolumn{9}{|c|}{ DM is the dummy variable for excess money growth (measured as annual rates of growth of $10 \%$ or more) } \\
\hline \multicolumn{9}{|c|}{ Ho: $\mathrm{M}$ is significantly and positively related to growth in all equations. } \\
\hline $\begin{array}{l}\text { Ho: } \mathrm{RI} \text { is sign } \\
\text { and } 4 \mathrm{~b} \text {. }\end{array}$ & & y related to grov & in equations 1 , & 2, and $2 \mathrm{~b} . \mathrm{H}$ & & & & \\
\hline
\end{tabular}




\section{Appendix 2: Table 6: Financial Development Proxy: DGDP}

\begin{tabular}{|c|c|c|c|c|c|c|c|c|}
\hline \multicolumn{9}{|c|}{ Dependent variable: Growth rate of real GDP per capita (sample period 1970-2002) } \\
\hline & \multicolumn{2}{|c|}{ All Countries } & \multicolumn{2}{|c|}{ Africa } & \multicolumn{2}{|c|}{ Latin America } & \multicolumn{2}{|c|}{ South-East Asia } \\
\hline $\mathrm{C}$ & $\begin{array}{c}0.636714 \\
(1.241928) \\
\end{array}$ & $\begin{array}{c}0.936228 \\
(1.808273) \\
\end{array}$ & $\begin{array}{c}1.209627 \\
(1.561390) \\
\end{array}$ & $\begin{array}{c}1.906548 \\
(2.522122)^{* *}\end{array}$ & $\begin{array}{c}2.539142 \\
(1.721417) \\
\end{array}$ & $\begin{array}{c}1.551427 \\
(1.038724) \\
\end{array}$ & $\begin{array}{c}-4.301630 \\
(-0.978343) \\
\end{array}$ & $\begin{array}{c}-4.041315 \\
(-0.918312)\end{array}$ \\
\hline GDP(-1) & $\begin{array}{c}-0.064303 \\
(-1.211474)\end{array}$ & $\begin{array}{c}-0.061765 \\
(-1.169097)\end{array}$ & $\begin{array}{c}-0.084639 \\
(-0.916133)\end{array}$ & $\begin{array}{c}-0.076104 \\
(-0.849309) \\
\end{array}$ & $\begin{array}{c}-0.038331 \\
(-0.643008)\end{array}$ & $\begin{array}{c}-0.017261 \\
(-0.282304)\end{array}$ & $\begin{array}{c}1.194265 \\
(1.435496)\end{array}$ & $\begin{array}{c}1.199878 \\
(1.447809)\end{array}$ \\
\hline RI & $\begin{array}{c}0.000530 \\
(0.964697) \\
\end{array}$ & $\begin{array}{c}0.000602 \\
(0.999707) \\
\end{array}$ & $\begin{array}{c}-0.027878 \\
(-0.996244) \\
\end{array}$ & $\begin{array}{c}-0.039414 \\
(-1.447283)^{*}\end{array}$ & $\begin{array}{c}0.000205 \\
(0.619666) \\
\end{array}$ & $\begin{array}{c}0.000150 \\
(0.479863) \\
\end{array}$ & $\begin{array}{c}0.020300 \\
(0.479035) \\
\end{array}$ & $\begin{array}{c}0.032448 \\
(0.744155) \\
\end{array}$ \\
\hline DGDP & $\begin{array}{c}4.235514 \\
(3.859902)^{* *}\end{array}$ & $\begin{array}{c}3.547707 \\
(3.498062)^{* *}\end{array}$ & $\begin{array}{c}3.995771 \\
(2.931631)^{* *}\end{array}$ & $\begin{array}{c}3.090618 \\
(2.336447)^{* *}\end{array}$ & $\begin{array}{c}-6.197412 \\
(-1.265309) \\
\end{array}$ & $\begin{array}{c}-4.003871 \\
(-0.820124) \\
\end{array}$ & $\begin{array}{l}2.2126635 \\
(0.929172)\end{array}$ & $\begin{array}{c}1.338871 \\
(0.586651)\end{array}$ \\
\hline INF & $\begin{array}{c}-0.005533 \\
(-2.101259) * * \\
\end{array}$ & $\begin{array}{c}-0.005923 \\
(-2.112104)^{* *}\end{array}$ & $\begin{array}{c}-0.065753 \\
(-2.393286)^{* *}\end{array}$ & $\begin{array}{c}-0.078830 \\
(-2.900402)^{* *}\end{array}$ & $\begin{array}{c}-0.004085 \\
(-2.617976)^{* *}\end{array}$ & $\begin{array}{c}-0.003718 \\
(-2.502373) * *\end{array}$ & $\begin{array}{c}-0.040323 \\
(-0.930369)\end{array}$ & $\begin{array}{c}-0.043319 \\
(-1.005860)\end{array}$ \\
\hline OPEN & $\begin{array}{c}0.198033 \\
(3.487750)^{* *}\end{array}$ & $\begin{array}{c}0.201842 \\
(3.540653)^{* *}\end{array}$ & $\begin{array}{c}0.219762 \\
(2.953599) * *\end{array}$ & $\begin{array}{c}0.222280 \\
(2.921568)^{* *}\end{array}$ & $\begin{array}{c}0.265529 \\
(1.454114) \\
\end{array}$ & $\begin{array}{c}0.247526 \\
(1.339211) \\
\end{array}$ & $\begin{array}{c}-0.945962 \\
(-1.323640)\end{array}$ & $\begin{array}{c}-0.791210 \\
(-1.184242)\end{array}$ \\
\hline $\mathrm{DM}$ & & $\begin{array}{c}-1.356186 \\
(-2.891030)^{* *}\end{array}$ & & $\begin{array}{c}-2.638875 \\
(-4.118925)^{* *}\end{array}$ & & $\begin{array}{c}1.610828 \\
(1.813922) \\
\end{array}$ & & $\begin{array}{c}-1.295045 \\
(-1.816502)^{* *}\end{array}$ \\
\hline $\begin{array}{c}\text { Adjusted } \\
\text { R-squared }\end{array}$ & 0.04 & 0.05 & 0.05 & 0.08 & 0.06 & 0.08 & 0.06 & 0.10 \\
\hline \multicolumn{9}{|c|}{ t-statistics in parentheses are White's heteroskedasticity-consistent t-statistics. $* * t$ statistics significant at $1 \% \quad *$ t-statistics significant at $5 \%$} \\
\hline \multicolumn{9}{|c|}{ The dependent variable is the growth rate of real gdp per capita } \\
\hline \multicolumn{9}{|c|}{ GDP(-1) is the initial level of real GDP } \\
\hline \multicolumn{9}{|c|}{ RI is real interest rates calculated according to the Fisher Identity } \\
\hline \multicolumn{9}{|c|}{ DGDP is the ratio of banking sector deposits to gdp (both numerator and denominator are in nominal values) } \\
\hline \multicolumn{9}{|c|}{ INF is the annual rate of increase in the GDP deflator } \\
\hline \multicolumn{9}{|c|}{ OPEN is the sum of lines 78 bed and 78 bid from the IMF's IFS database } \\
\hline \multicolumn{9}{|c|}{ DM is the dummy variable for excess money growth (measured as annual rates of growth of $10 \%$ or more) } \\
\hline \multicolumn{9}{|c|}{ Ho: DGDP is significantly and positively related to growth in all equations. } \\
\hline $\begin{array}{l}\text { Ho: } \mathrm{RI} \text { is sign } \\
\text { and } 4 \mathrm{~b} \text {. }\end{array}$ & & & & & & & & \\
\hline
\end{tabular}




\section{Appendix 2: Table 7: Financial Repression Variable: FR; Financial Development Proxy: M}

\begin{tabular}{|c|c|c|c|c|c|c|c|c|}
\hline \multicolumn{9}{|c|}{ Dependent variable: Growth rate of real GDP per capita (sample period 1970-2002) } \\
\hline & \multicolumn{2}{|c|}{ All Countries } & \multicolumn{2}{|c|}{ Africa } & \multicolumn{2}{|c|}{ Latin America } & \multicolumn{2}{|c|}{ South-East Asia } \\
\hline $\mathrm{C}$ & $\begin{array}{c}1.568717 \\
(2.535314)^{* *}\end{array}$ & $\begin{array}{c}1.719512 \\
(2.787565) * *\end{array}$ & $\begin{array}{c}2.616355 \\
(3.080592)^{* *}\end{array}$ & $\begin{array}{c}2.952499 \\
(3.522414) * *\end{array}$ & $\begin{array}{c}0.148234 \\
(0.083066)\end{array}$ & $\begin{array}{c}-0.231335 \\
(-0.128523)\end{array}$ & $\begin{array}{c}-1.121635 \\
(-0.300035)\end{array}$ & $\begin{array}{c}-1.011934 \\
(-0.274872)\end{array}$ \\
\hline $\operatorname{GDP}(-1)$ & $\begin{array}{c}-0.023173 \\
(-0.467828) \\
\end{array}$ & $\begin{array}{c}-0.025713 \\
(-0.526762) \\
\end{array}$ & $\begin{array}{c}0.056253 \\
(0.604061) \\
\end{array}$ & $\begin{array}{c}0.034495 \\
(0.379528) \\
\end{array}$ & $\begin{array}{c}-0.016851 \\
(-0.286443) \\
\end{array}$ & $\begin{array}{c}-0.002661 \\
(-0.044487)\end{array}$ & $\begin{array}{c}0.760507 \\
(1.133501) \\
\end{array}$ & $\begin{array}{c}0.801135 \\
(1.233191) \\
\end{array}$ \\
\hline FR & $\begin{array}{c}-0.158603 \\
(-2.708823)^{* *}\end{array}$ & $\begin{array}{c}-0.136280 \\
(-2.359584)^{* *}\end{array}$ & $\begin{array}{c}-0.239393 \\
(-3.475372)^{* *}\end{array}$ & $\begin{array}{c}-0.195239 \\
(-2.860332)^{* * *}\end{array}$ & $\begin{array}{c}0.359880 \\
(1.256131)\end{array}$ & $\begin{array}{c}0.285001 \\
(0.993561)\end{array}$ & $\begin{array}{c}0.055648 \\
(0.299931) \\
\end{array}$ & $\begin{array}{c}0.136621 \\
(0.693468)\end{array}$ \\
\hline M & $\begin{array}{c}\mathbf{0 . 0 0 8 6 1 7} \\
(\mathbf{0 . 8 4 6 7 5 3 )} \\
\end{array}$ & $\begin{array}{c}0.009156 \\
(0.911235) \\
\end{array}$ & $\begin{array}{c}-0.026053 \\
(-1.930438)\end{array}$ & $\begin{array}{c}-0.022919 \\
(-1.721531)\end{array}$ & $\begin{array}{c}0.004461 \\
(0.076646) \\
\end{array}$ & $\begin{array}{c}0.007663 \\
(0.131046) \\
\end{array}$ & $\begin{array}{c}-0.022557 \\
(-0.865526) \\
\end{array}$ & $\begin{array}{c}-0.026591 \\
(-1.045750)\end{array}$ \\
\hline INF & $\begin{array}{c}-0.004388 \\
(-4.265032)^{* *} \\
\end{array}$ & $\begin{array}{c}-0.004503 \\
(-4.253011)^{* *} \\
\end{array}$ & $\begin{array}{c}-0.050525 \\
(-3.650035) * * \\
\end{array}$ & $\begin{array}{c}-0.053506 \\
(-3.888519)^{* *} \\
\end{array}$ & $\begin{array}{c}-0.003321 \\
(-5.627219) * * \\
\end{array}$ & $\begin{array}{c}-0.003126 \\
(-5.261700)^{* *} \\
\end{array}$ & $\begin{array}{c}-0.042895 \\
(-0.959747) \\
\end{array}$ & $\begin{array}{c}-0.057499 \\
(-1.288916)^{* *} \\
\end{array}$ \\
\hline OPEN & $\begin{array}{c}0.216454 \\
(3.657397)^{* *}\end{array}$ & $\begin{array}{c}0.219822 \\
(3.684691)^{* *}\end{array}$ & $\begin{array}{c}0.218746 \\
(2.843832)^{* *}\end{array}$ & $\begin{array}{c}0.222573 \\
(2.849249) * *\end{array}$ & $\begin{array}{c}0.241603 \\
(1.204409) \\
\end{array}$ & $\begin{array}{c}0.231439 \\
(1.141297) \\
\end{array}$ & $\begin{array}{c}0.249325 \\
(-0.872533) \\
\end{array}$ & $\begin{array}{c}0.286616 \\
(1.100273) \\
\end{array}$ \\
\hline DM & & $\begin{array}{c}-1.381757 \\
(-2.955714)^{* *}\end{array}$ & & $\begin{array}{c}-2.359342 \\
(-3.814242)^{* * *}\end{array}$ & & $\begin{array}{c}1.663402 \\
(1.887061) \\
\end{array}$ & & $\begin{array}{c}-2.371291 \\
(-2.912096)^{* *}\end{array}$ \\
\hline $\begin{array}{c}\text { Adjusted } \\
\text { R-squared }\end{array}$ & 0.04 & 0.05 & 0.06 & 0.08 & 0.04 & 0.06 & 0.04 & 0.08 \\
\hline \multicolumn{9}{|c|}{ t-statistics in parentheses are White's heteroskedasticity-consistent t-statistics. $* * t$ statistics significant at $1 \%$} \\
\hline \multicolumn{9}{|c|}{ The dependent variable is the growth rate of real gdp per capita } \\
\hline \multicolumn{9}{|c|}{ GDP(-1) is the initial level of real GDP } \\
\hline \multicolumn{9}{|c|}{ FR is the ratio of CB to DGDP (both numerator and denominator are in nominal values) } \\
\hline \multicolumn{9}{|c|}{$\mathrm{M}$ is the ratio of M2 to gdp (both numerator and denominator are in nominal values) } \\
\hline \multicolumn{9}{|c|}{ INF is the annual rate of increase in the GDP deflator } \\
\hline \multicolumn{9}{|c|}{ OPEN is the sum of lines 78bed and 78 bid from the IMF's IFS database } \\
\hline \multicolumn{9}{|c|}{ DM is the dummy variable for excess money growth (measured as annual rates of growth of $10 \%$ or more) } \\
\hline \multicolumn{9}{|c|}{ Ho: $\mathrm{M}$ is significantly and positively related to growth in all equations. } \\
\hline $\begin{array}{l}\text { Ho: FR is sigi } \\
4 \text { and } 4 b \text {. }\end{array}$ & & & & & & & & \\
\hline
\end{tabular}




\section{Appendix 2: Table 8: Financial Repression Variable: FR; Financial Development Proxy: M}

(Sample Period 1970 - 1980)

\begin{tabular}{|c|c|c|c|c|c|c|c|c|}
\hline \multicolumn{9}{|c|}{ Dependent variable: Growth rate of real GDP per capita (sample period 1970-1980) } \\
\hline & \multicolumn{2}{|c|}{ All Countries } & \multicolumn{2}{|c|}{ Africa } & \multicolumn{2}{|c|}{ Latin America } & \multicolumn{2}{|c|}{ South-East Asia } \\
\hline $\mathrm{C}$ & $\begin{array}{c}5.045396 \\
(2.818264) * *\end{array}$ & $\begin{array}{c}5.123756 \\
(2.733974)^{* *}\end{array}$ & $\begin{array}{c}8.327311 \\
(3.831103) * *\end{array}$ & $\begin{array}{c}8.353643 \\
(3.823159) * * \\
\end{array}$ & $\begin{array}{c}0.113675 \\
(0.027225) \\
\end{array}$ & $\begin{array}{c}-0.526879 \\
(-0.126129) \\
\end{array}$ & $\begin{array}{c}-13.12460 \\
(-1.912062)^{* *}\end{array}$ & $\begin{array}{c}-13.26749 \\
(-1.821479) \\
\end{array}$ \\
\hline GDP(-1) & $\begin{array}{c}-0.103302 \\
(-0.914783) \\
\end{array}$ & $\begin{array}{c}-0.115272 \\
(-0.897036) \\
\end{array}$ & $\begin{array}{c}-0.300012 \\
(-1.661219) \\
\end{array}$ & $\begin{array}{c}-0.326249 \\
(-1.808307) \\
\end{array}$ & $\begin{array}{c}0.121445 \\
(1.018953) \\
\end{array}$ & $\begin{array}{c}0.169578 \\
(1.387617) \\
\end{array}$ & $\begin{array}{c}2.461264 \\
(3.260820)^{* *}\end{array}$ & $\begin{array}{c}2.475249 \\
(3.150017)^{* * *}\end{array}$ \\
\hline FR & $\begin{array}{c}-0.413901 \\
(-3.696771)^{* *}\end{array}$ & $\begin{array}{c}-0.387375 \\
(-3.504918) * *\end{array}$ & $\begin{array}{c}-0.460443 \\
(-3.520719) * *\end{array}$ & $\begin{array}{c}-0.385471 \\
(-2.876355)^{* *}\end{array}$ & $\begin{array}{c}0.013668 \\
(0.034834)\end{array}$ & $\begin{array}{c}-0.006252 \\
(-0.016006)\end{array}$ & $\begin{array}{c}0.049182 \\
(0.126126)\end{array}$ & $\begin{array}{c}0.041571 \\
(0.110223)\end{array}$ \\
\hline M & $\begin{array}{c}-0.045254 \\
(-0.791719) \\
\end{array}$ & $\begin{array}{c}-0.040869 \\
(-0.682915) \\
\end{array}$ & $\begin{array}{c}-0.076786 \\
(-1.342261) \\
\end{array}$ & $\begin{array}{c}-0.061873 \\
(-1.072580) \\
\end{array}$ & $\begin{array}{c}0.040339 \\
(0.238051) \\
\end{array}$ & $\begin{array}{c}0.026157 \\
(0.161781) \\
\end{array}$ & $\begin{array}{c}0.052350 \\
(0.558932) \\
\end{array}$ & $\begin{array}{c}0.053731 \\
(0.551627) \\
\end{array}$ \\
\hline INF & $\begin{array}{c}-0.017674 \\
(-2.266679) * * \\
\end{array}$ & $\begin{array}{c}-0.017417 \\
(-2.223484) \\
\end{array}$ & $\begin{array}{c}-0.095267 \\
(-2.254485)^{* *}\end{array}$ & $\begin{array}{c}-0.103795 \\
(-2.471168)^{* *}\end{array}$ & $\begin{array}{c}-0.007866 \\
(-0.830663) \\
\end{array}$ & $\begin{array}{c}-0.008990 \\
(-1.066326) \\
\end{array}$ & $\begin{array}{c}0.047378 \\
(0.816866) \\
\end{array}$ & $\begin{array}{c}0.049380 \\
(0.775755) \\
\end{array}$ \\
\hline OPEN & $\begin{array}{c}0.353772 \\
(2.235993)^{* *}\end{array}$ & $\begin{array}{c}0.363612 \\
\left(2.219000^{* *}\right. \\
\end{array}$ & $\begin{array}{c}0.312063 \\
(1.828666) \\
\end{array}$ & $\begin{array}{c}0.333458 \\
(1.842455) \\
\end{array}$ & $\begin{array}{c}0.515855 \\
(1.247132) \\
\end{array}$ & $\begin{array}{c}0.605797 \\
(1.560917) \\
\end{array}$ & $\begin{array}{c}-0.072442 \\
(-0.138134) \\
\end{array}$ & $\begin{array}{c}-0.082394 \\
(-0.154189) \\
\end{array}$ \\
\hline $\mathrm{DM}$ & & $\begin{array}{c}-0.855530 \\
(-1.338012) \\
\end{array}$ & & $\begin{array}{c}-2.335281 \\
(-2.248957)^{* *}\end{array}$ & & $\begin{array}{c}2.085771 \\
(1.675416) \\
\end{array}$ & & $\begin{array}{c}0.236392 \\
(0.180983) \\
\end{array}$ \\
\hline $\begin{array}{c}\text { Adjusted } \\
\text { R-squared }\end{array}$ & 0.08 & 0.09 & 0.15 & 0.17 & 0.04 & 0.09 & 0.16 & 0.16 \\
\hline \multirow{2}{*}{\multicolumn{9}{|c|}{$\begin{array}{l}\text { t-statistics in parentheses are White's heteroskedasticity-consistent t-statistics. } * * \text { t statistics significant at } 1 \% \\
\text { The dependent variable is the growth rate of real gdp per capita }\end{array}$}} \\
\hline & & & & & & & & \\
\hline \multicolumn{9}{|c|}{ GDP(-1) is the initial level of real GDP } \\
\hline \multicolumn{9}{|c|}{ FR is the ratio of CB to DGDP (both numerator and denominator are in nominal values) } \\
\hline \multicolumn{9}{|c|}{$\mathrm{M}$ is the ratio of M2 to gdp (both numerator and denominator are in nominal values) } \\
\hline \multicolumn{9}{|c|}{ INF is the annual rate of increase in the GDP deflator } \\
\hline \multicolumn{9}{|c|}{ OPEN is the sum of lines $78 \mathrm{bed}$ and 78 bid from the IMF's IFS database } \\
\hline \multicolumn{9}{|c|}{ DM is the dummy variable for excess money growth (measured as annual rates of growth of $10 \%$ or more) } \\
\hline \multicolumn{9}{|c|}{ Ho: $\mathrm{M}$ is significantly and positively related to growth in all equations. } \\
\hline $\begin{array}{l}\text { Ho: FR is sign } \\
4 \text { and } 4 \mathrm{~b} \text {. }\end{array}$ & & & & & & & & \\
\hline
\end{tabular}




\section{Appendix 2: Table 9: Financial Repression Variable: FR; Financial Development Proxy: M \\ (Sample Period 1981 - 1990)}

\begin{tabular}{|c|c|c|c|c|c|c|c|c|}
\hline \multicolumn{9}{|c|}{ Dependent variable: Growth rate of real GDP per capita (sample period 1981-1990) } \\
\hline & \multicolumn{2}{|c|}{ All Countries } & \multicolumn{2}{|c|}{ Africa } & \multicolumn{2}{|c|}{ Latin America } & \multicolumn{2}{|c|}{ South-East Asia } \\
\hline $\mathrm{C}$ & $\begin{array}{c}-0.891531 \\
(-0.880904) \\
\end{array}$ & $\begin{array}{c}0.751330 \\
(-0.728321) \\
\end{array}$ & $\begin{array}{c}-0.310093 \\
(-0.210461) \\
\end{array}$ & $\begin{array}{c}0.088751 \\
(0.061572) \\
\end{array}$ & $\begin{array}{c}-5.039613 \\
(-1.413691) \\
\end{array}$ & $\begin{array}{c}-5.043517 \\
(-1.392953) \\
\end{array}$ & $\begin{array}{c}12.97648 \\
(3.103343)^{* *}\end{array}$ & $\begin{array}{c}12.96224 \\
(3.055211)^{* * *}\end{array}$ \\
\hline $\operatorname{GDP}(-1)$ & $\begin{array}{c}0.066888 \\
(0.722757)\end{array}$ & $\begin{array}{c}0.056670 \\
(0.609914) \\
\end{array}$ & $\begin{array}{c}0.285943 \\
(1.292263) \\
\end{array}$ & $\begin{array}{c}0.244193 \\
(1.100496) \\
\end{array}$ & $\begin{array}{c}0.147732 \\
(1.307192) \\
\end{array}$ & $\begin{array}{c}0.131644 \\
(1.175552) \\
\end{array}$ & $\begin{array}{c}-2.952711 \\
(-3.003219)^{* *} \\
\end{array}$ & $\begin{array}{c}-2.940409 \\
(-2.926726)^{* *} \\
\end{array}$ \\
\hline FR & $\begin{array}{c}0.029742 \\
(0.272408) \\
\end{array}$ & $\begin{array}{c}0.070555 \\
(0.594892) \\
\end{array}$ & $\begin{array}{c}-0.122054 \\
(-0.802228)\end{array}$ & $\begin{array}{c}-0.061990 \\
(-0.401740)\end{array}$ & $\begin{array}{c}0.464277 \\
(0.650113)\end{array}$ & $\begin{array}{c}0.594383 \\
(0.822341)\end{array}$ & $\begin{array}{c}0.556816 \\
(1.695928) \\
\end{array}$ & $\begin{array}{c}0.555994 \\
(1.675997) \\
\end{array}$ \\
\hline M & $\begin{array}{c}0.036718 \\
(2.291482)^{* *}\end{array}$ & $\begin{array}{c}0.039474 \\
(2.317245)^{* *} \\
\end{array}$ & $\begin{array}{c}-0.009081 \\
(-0.461158) \\
\end{array}$ & $\begin{array}{c}-0.006626 \\
(-0.336250) \\
\end{array}$ & $\begin{array}{c}0.060868 \\
(0.623307) \\
\end{array}$ & $\begin{array}{c}0.068332 \\
(0.714024) \\
\end{array}$ & $\begin{array}{c}0.184958 \\
(4.481832)^{* *}\end{array}$ & $\begin{array}{c}0.184103 \\
(4.359496)^{* *} \\
\end{array}$ \\
\hline INF & $\begin{array}{c}-0.003420 \\
(-5.065660) * *\end{array}$ & $\begin{array}{c}-0.003548 \\
(-5.064256) * *\end{array}$ & $\begin{array}{c}-0.037121 \\
(-1.813150)^{* *}\end{array}$ & $\begin{array}{c}-0.042642 \\
(-2.004129) * *\end{array}$ & $\begin{array}{c}-0.002302 \\
(-3.193365) * *\end{array}$ & $\begin{array}{c}-0.002386 \\
(-3.278035) * *\end{array}$ & $\begin{array}{c}-0.134388 \\
(-3.114034)^{* *}\end{array}$ & $\begin{array}{c}-0.135244 \\
(-3.122402) * *\end{array}$ \\
\hline OPEN & $\begin{array}{c}0.392780 \\
(1.696835) \\
\end{array}$ & $\begin{array}{c}0.398503 \\
(1.743291) \\
\end{array}$ & $\begin{array}{c}0.330661 \\
(1.302822) \\
\end{array}$ & $\begin{array}{c}0.342370 \\
(1.333937) \\
\end{array}$ & $\begin{array}{c}1.126626 \\
(2.542969) * *\end{array}$ & $\begin{array}{c}1.062832 \\
(2.333124)^{* *}\end{array}$ & $\begin{array}{c}2.669747 \\
(4.305904) * *\end{array}$ & $\begin{array}{c}2.664829 \\
(4.224067) * *\end{array}$ \\
\hline $\mathrm{DM}$ & & $\begin{array}{c}-2.108267 \\
(-2.080876)^{* *}\end{array}$ & & $\begin{array}{c}-2.450042 \\
(-2.021172)^{* *}\end{array}$ & & $\begin{array}{c}-1.622150 \\
(-0.608171) \\
\end{array}$ & & $\begin{array}{c}-0.213488 \\
(-0.354785) \\
\end{array}$ \\
\hline $\begin{array}{c}\text { Adjusted } \\
\text { R-squared }\end{array}$ & 0.08 & 0.10 & 0.07 & 0.09 & 0.19 & 0.20 & 0.62 & 0.65 \\
\hline \multicolumn{9}{|c|}{ t-statistics in parentheses are White's heteroskedasticity-consistent t-statistics. $* * t$ statistics significant at $1 \% * t$-statistics significant at $5 \%$} \\
\hline \multicolumn{9}{|c|}{ The dependent variable is the growth rate of real gdp per capita } \\
\hline \multicolumn{9}{|c|}{ GDP(-1) is the initial level of real GDP } \\
\hline \multicolumn{9}{|c|}{ FR is the ratio of CB to DGDP (both numerator and denominator are in nominal values) } \\
\hline \multicolumn{9}{|c|}{$\mathrm{M}$ is the ratio of M2 to gdp (both numerator and denominator are in nominal values) } \\
\hline \multicolumn{9}{|c|}{ INF is the annual rate of increase in the GDP deflator } \\
\hline \multicolumn{9}{|c|}{ OPEN is the sum of lines 78bed and 78 bid from the IMF's IFS database } \\
\hline \multicolumn{9}{|c|}{ DM is the dummy variable for excess money growth (measured as annual rates of growth of $10 \%$ or more) } \\
\hline \multicolumn{9}{|c|}{ Ho: $\mathrm{M}$ is significantly and positively related to growth in all equations. } \\
\hline $\begin{array}{l}\text { Ho: FR is sign } \\
4 \text { and } 4 b \text {. }\end{array}$ & & & & & & & & \\
\hline
\end{tabular}




\section{Appendix 2: Table 10: Financial Repression Variable: FR; Financial Development Proxy: M}

(Sample Period 1991 - 2002)

\begin{tabular}{|c|c|c|c|c|c|c|c|c|}
\hline \multicolumn{9}{|c|}{ Dependent variable: Growth rate of real GDP per capita (sample period 1991-2002) } \\
\hline & \multicolumn{2}{|c|}{ All Countries } & \multicolumn{2}{|c|}{ Africa } & \multicolumn{2}{|c|}{ Latin America } & \multicolumn{2}{|c|}{ South-East Asia } \\
\hline & 1 & $1 b$ & 2 & $2 b$ & 3 & $3 b$ & 4 & $4 b$ \\
\hline $\mathrm{C}$ & $\begin{array}{c}0.804313 \\
(0.939061)\end{array}$ & $\begin{array}{c}1.035886 \\
(1.268999)\end{array}$ & $\begin{array}{c}-0.319317 \\
(-0.262740)\end{array}$ & $\begin{array}{c}0.149573 \\
(0.130193)\end{array}$ & $\begin{array}{c}-3.100335 \\
(-0.801495)\end{array}$ & $\begin{array}{c}-2.644706 \\
(-0.719923)\end{array}$ & $\begin{array}{c}-3.512619 \\
(-0.553781)\end{array}$ & $\begin{array}{c}-4.531404 \\
(-0.728054)\end{array}$ \\
\hline GDP(-1) & $\begin{array}{c}0.057318 \\
(0.760557)\end{array}$ & $\begin{array}{c}0.058396 \\
(0.768300)\end{array}$ & $\begin{array}{c}0.260865 \\
(1.747940)\end{array}$ & $\begin{array}{c}0.251137 \\
(1.740401)\end{array}$ & $\begin{array}{c}-0.111340 \\
(-1.422847)\end{array}$ & $\begin{array}{c}-0.077767 \\
(-0.955725)\end{array}$ & $\begin{array}{c}1.742451 \\
(1.333611)\end{array}$ & $\begin{array}{c}1.925423 \\
(1.594486)\end{array}$ \\
\hline FR & $\begin{array}{c}-0.175649 \\
(-1.828064)\end{array}$ & $\begin{array}{c}-0.160447 \\
(-1.735695)\end{array}$ & $\begin{array}{c}-0.255099 \\
(-2.211379) * *\end{array}$ & $\begin{array}{c}-0.232452 \\
(-2.048807)^{* * *}\end{array}$ & $\begin{array}{c}1.108383 \\
(1.453407)\end{array}$ & $\begin{array}{c}0.584063 \\
(0.872119)\end{array}$ & $\begin{array}{c}0.885579 \\
(2.451942) * *\end{array}$ & $\begin{array}{c}0.864292 \\
(2.445016) * *\end{array}$ \\
\hline M & $\begin{array}{c}0.011508 \\
(0.884304)\end{array}$ & $\begin{array}{c}0.009761 \\
(0.796442)\end{array}$ & $\begin{array}{c}-0.007494 \\
(-0.479371) \\
\end{array}$ & $\begin{array}{c}-0.007168 \\
(-0.476188)\end{array}$ & $\begin{array}{c}0.111966 \\
(1.038955)\end{array}$ & $\begin{array}{c}0.110379 \\
(1.041040)\end{array}$ & $\begin{array}{c}-0.080643 \\
(-1.944648)\end{array}$ & $\begin{array}{c}-0.083644 \\
(-2.336043)^{* *}\end{array}$ \\
\hline INF & $\begin{array}{c}-0.143034 \\
(-1.720979)\end{array}$ & $\begin{array}{c}-0.030198 \\
(-1.706563)\end{array}$ & $\begin{array}{c}-0.035392 \\
(-1.718452)\end{array}$ & $\begin{array}{c}-0.036729 \\
(-1.842284)\end{array}$ & $\begin{array}{c}0.011985 \\
(0.379787)\end{array}$ & $\begin{array}{c}0.010919 \\
(0.388562)\end{array}$ & $\begin{array}{c}-0.391799 \\
(-2.805478) * *\end{array}$ & $\begin{array}{c}-0.353223 \\
(-2.753966)^{* *}\end{array}$ \\
\hline OPEN & $\begin{array}{c}0.128355 \\
(2.367374)^{* *}\end{array}$ & $\begin{array}{c}0.127187 \\
(2.490376)^{* *}\end{array}$ & $\begin{array}{c}0.136324 \\
(2.276413)^{* *}\end{array}$ & $\begin{array}{c}0.128949 \\
(1.318335)\end{array}$ & $\begin{array}{c}0.169634 \\
(0.478073)\end{array}$ & $\begin{array}{c}0.052496 \\
(0.152685)\end{array}$ & $\begin{array}{c}-0.051136 \\
(-0.127370)\end{array}$ & $\begin{array}{c}0.073502 \\
(0.209352)\end{array}$ \\
\hline $\mathrm{DM}$ & & $\begin{array}{c}-1.413347 \\
(-1.858775)\end{array}$ & & $\begin{array}{c}-2.427793 \\
(-2.225852)^{* *}\end{array}$ & & $\begin{array}{c}2.688793 \\
(2.531275)\end{array}$ & & $\begin{array}{c}-3.141005 \\
(-2.267492)^{* *}\end{array}$ \\
\hline $\begin{array}{c}\text { Adjusted } \\
\text { R-squared }\end{array}$ & 0.05 & 0.06 & 0.06 & 0.09 & 0.05 & 0.10 & 0.17 & 0.24 \\
\hline \multicolumn{9}{|c|}{ t-statistics in parentheses are White's heteroskedasticity-consistent t-statistics. $* * t$ statistics significant at $1 \% * t$-statistics significant at $5 \%$} \\
\hline \multicolumn{9}{|c|}{ The dependent variable is the growth rate of real gdp per capita } \\
\hline \multicolumn{9}{|c|}{ GDP(-1) is the initial level of real GDP } \\
\hline \multicolumn{9}{|c|}{ FR is the ratio of CB to DGDP (both numerator and denominator are in nominal values) } \\
\hline \multicolumn{9}{|c|}{$\mathrm{M}$ is the ratio of M2 to gdp (both numerator and denominator are in nominal values) } \\
\hline \multicolumn{9}{|c|}{ INF is the annual rate of increase in the GDP deflator } \\
\hline \multicolumn{9}{|c|}{ OPEN is the sum of lines 78 bed and 78 bid from the IMF's IFS database } \\
\hline \multicolumn{9}{|c|}{ DM is the dummy variable for excess money growth (measured as annual rates of growth of $10 \%$ or more) } \\
\hline \multicolumn{9}{|c|}{ Ho: $\mathrm{M}$ is significantly and positively related to growth in all equations. } \\
\hline $\begin{array}{l}\text { Ho: FR is sigr } \\
4 \text { and } 4 b \text {. }\end{array}$ & & & & & & & & \\
\hline
\end{tabular}




\section{Appendix 2: Table 11: Financial Repression Variable: FR; Financial Development Proxy: M} (Sample Period 1970 - 1978)

\begin{tabular}{|c|c|c|c|c|c|c|c|c|}
\hline \multicolumn{9}{|c|}{ Dependent variable: Growth rate of real GDP per capita (sample period 1970-1978) } \\
\hline & \multicolumn{2}{|c|}{ All Countries } & \multicolumn{2}{|c|}{ Africa } & \multicolumn{2}{|c|}{ Latin America } & \multicolumn{2}{|c|}{ South-East Asia } \\
\hline & 1 & $1 b$ & 2 & $2 b$ & 3 & $3 \boldsymbol{b}$ & 4 & $4 b$ \\
\hline $\mathrm{C}$ & $\begin{array}{c}3.900049 \\
(2.039269) * *\end{array}$ & $\begin{array}{c}3.791864 \\
(1.951496)\end{array}$ & $\begin{array}{c}7.108881 \\
(3.057449)^{* *}\end{array}$ & $\begin{array}{c}7.025788 \\
(2.966335)\end{array}$ & $\begin{array}{c}-2.212883 \\
(-0.500946)\end{array}$ & $\begin{array}{c}-2.362893 \\
(-0.535395)\end{array}$ & $\begin{array}{c}-19.73487 \\
(-2.260050) * *\end{array}$ & $\begin{array}{c}-19.64656 \\
(-2.151328) * *\end{array}$ \\
\hline GDP(-1) & $\begin{array}{c}0.002029 \\
(0.020835)\end{array}$ & $\begin{array}{c}0.004413 \\
(0.044114) \\
\end{array}$ & $\begin{array}{c}-0.094294 \\
(-0.603320)\end{array}$ & $\begin{array}{c}-0.130931 \\
(-0.799662) \\
\end{array}$ & $\begin{array}{c}0.165352 \\
(1.409825) \\
\end{array}$ & $\begin{array}{c}0.201930 \\
(1.689823) \\
\end{array}$ & $\begin{array}{c}3.625659 \\
(3.454344)^{* *}\end{array}$ & $\begin{array}{c}3.626426 \\
(3.417184) * *\end{array}$ \\
\hline FR & $\begin{array}{c}-0.340327 \\
(-3.167335)^{* *}\end{array}$ & $\begin{array}{c}-0.299229 \\
(-2.742175)^{* *}\end{array}$ & $\begin{array}{c}-0.434521 \\
(-3.244185)^{* *}\end{array}$ & $\begin{array}{c}-0.343519 \\
(-2.390698) * *\end{array}$ & $\begin{array}{c}0.183281 \\
(0.414882)\end{array}$ & $\begin{array}{c}0.158690 \\
(0.352923)\end{array}$ & $\begin{array}{c}0.062308 \\
(0.151925)\end{array}$ & $\begin{array}{c}0.065204 \\
(0.158583)\end{array}$ \\
\hline M & $\begin{array}{c}-0.022338 \\
(-0.410327)\end{array}$ & $\begin{array}{c}-0.013847 \\
(-0.252687)\end{array}$ & $\begin{array}{c}-0.078123 \\
(-1.121132)\end{array}$ & $\begin{array}{c}-0.056744 \\
(-0.797140)\end{array}$ & $\begin{array}{c}0.119523 \\
(0.665624)\end{array}$ & $\begin{array}{c}0.090038 \\
(0.525726)\end{array}$ & $\begin{array}{c}0.078080 \\
(0.749482)\end{array}$ & $\begin{array}{c}0.076423 \\
(0.689479)\end{array}$ \\
\hline INF & $\begin{array}{c}-0.019727 \\
(-2.679510) * *\end{array}$ & $\begin{array}{c}-0.019058 \\
(-2.612949)\end{array}$ & $\begin{array}{c}-0.087197 \\
(-1.882460)\end{array}$ & $\begin{array}{c}-0.093640 \\
(-2.089946)^{* *}\end{array}$ & $\begin{array}{c}-0.008813 \\
(-1.107003)\end{array}$ & $\begin{array}{c}-0.010418 \\
(-1.543864)\end{array}$ & $\begin{array}{c}0.062858 \\
(1.014226)\end{array}$ & $\begin{array}{c}0.060857 \\
(0.886571)\end{array}$ \\
\hline OPEN & $\begin{array}{c}0.380963 \\
(1.379717)\end{array}$ & $\begin{array}{c}0.391670 \\
(1.393849)\end{array}$ & $\begin{array}{c}0.267722 \\
(0.850026)\end{array}$ & $\begin{array}{c}0.330520 \\
(0.992682)\end{array}$ & $\begin{array}{c}0.219374 \\
(0.532934)\end{array}$ & $\begin{array}{c}0.293981 \\
(0.738824)\end{array}$ & $\begin{array}{c}-0.647553 \\
(-1.026816)\end{array}$ & $\begin{array}{c}-0.645835 \\
(-1.018350)\end{array}$ \\
\hline DM & & $\begin{array}{c}-1.392118 \\
(-1.879270) \\
\end{array}$ & & $\begin{array}{c}-2.705777 \\
(-2.451889)^{* * *}\end{array}$ & & $\begin{array}{c}1.655517 \\
(1.271353) \\
\end{array}$ & & $\begin{array}{c}-0.218533 \\
(-0.151515) \\
\end{array}$ \\
\hline $\begin{array}{c}\text { Adjusted } \\
\text { R-squared }\end{array}$ & 0.04 & 0.05 & 0.07 & 0.09 & 0.04 & 0.05 & 0.20 & 0.19 \\
\hline \multicolumn{9}{|c|}{ t-statistics in parentheses are White's heteroskedasticity-consistent t-statistics. $* * t$ statistics significant at $1 \%$} \\
\hline \multicolumn{9}{|c|}{ The dependent variable is the growth rate of real gdp per capita } \\
\hline \multicolumn{9}{|c|}{ GDP(-1) is the initial level of real GDP } \\
\hline \multicolumn{9}{|c|}{ FR is the ratio of CB to DGDP (both numerator and denominator are in nominal values) } \\
\hline \multicolumn{9}{|c|}{$\mathrm{M}$ is the ratio of M2 to gdp (both numerator and denominator are in nominal values) } \\
\hline \multicolumn{9}{|c|}{ INF is the annual rate of increase in the GDP deflator } \\
\hline \multicolumn{9}{|c|}{ OPEN is the sum of lines 78bed and 78 bid from the IMF's IFS database } \\
\hline \multicolumn{9}{|c|}{ DM is the dummy variable for excess money growth (measured as annual rates of growth of $10 \%$ or more) } \\
\hline \multicolumn{9}{|c|}{ Ho: $\mathrm{M}$ is significantly and positively related to growth in all equations. } \\
\hline $\begin{array}{l}\text { Ho: FR is sig } \\
4 \text { and } 4 \mathrm{~b} \text {. }\end{array}$ & & & $\therefore$ & 2 r & & & & \\
\hline
\end{tabular}




\section{Appendix 2: Table 12: Financial Repression Variable: FR; Financial Development Proxy: M}

(Sample Period 1979 - 2002)

\begin{tabular}{|c|c|c|c|c|c|c|c|c|}
\hline \multicolumn{9}{|c|}{ Dependent variable: Growth rate of real GDP per capita (sample period 1979-2002)) } \\
\hline & \multicolumn{2}{|c|}{ All Countries } & \multicolumn{2}{|c|}{ Africa } & \multicolumn{2}{|c|}{ Latin America } & \multicolumn{2}{|c|}{ South-East Asia } \\
\hline & 1 & $1 b$ & 2 & $2 b$ & 3 & $3 b$ & 4 & $4 b$ \\
\hline $\mathrm{C}$ & $\begin{array}{c}0.445969 \\
(0.671958) \\
\end{array}$ & $\begin{array}{c}0.632238 \\
(0.965315) \\
\end{array}$ & $\begin{array}{c}0.715837 \\
(0.777964) \\
\end{array}$ & $\begin{array}{c}1.099134 \\
(1.231649) \\
\end{array}$ & $\begin{array}{c}-0.708095 \\
(-0.297890) \\
\end{array}$ & $\begin{array}{c}-0.828094 \\
(-0.352323) \\
\end{array}$ & $\begin{array}{c}4.206242 \\
(1.122860) \\
\end{array}$ & $\begin{array}{c}3.785559 \\
(1.050780) \\
\end{array}$ \\
\hline GDP(-1) & $\begin{array}{c}0.021221 \\
(0.363434) \\
\end{array}$ & $\begin{array}{c}0.020226 \\
(0.351623) \\
\end{array}$ & $\begin{array}{c}0.164964 \\
(1.389365) \\
\end{array}$ & $\begin{array}{c}0.155259 \\
(1.338770) \\
\end{array}$ & $\begin{array}{c}-0.049249 \\
(-0.744694) \\
\end{array}$ & $\begin{array}{c}-0.032586 \\
(-0.493821) \\
\end{array}$ & $\begin{array}{c}0.026353 \\
(0.032298) \\
\end{array}$ & $\begin{array}{c}0.165980 \\
(0.213617) \\
\end{array}$ \\
\hline FR & $\begin{array}{c}-0.132446 \\
(-1.754733)^{* *}\end{array}$ & $\begin{array}{c}-0.114917 \\
(-1.551530) \\
\end{array}$ & $\begin{array}{c}-0.219226 \\
(-2.446983) * *\end{array}$ & $\begin{array}{c}-0.191198 \\
(2.174164)^{* *}\end{array}$ & $\begin{array}{c}0.566709 \\
(1.201677) \\
\end{array}$ & $\begin{array}{c}0.426818 \\
(0.932494) \\
\end{array}$ & $\begin{array}{c}0.372458 \\
(1.270471) \\
\end{array}$ & $\begin{array}{c}0.430184 \\
(1.421546) \\
\end{array}$ \\
\hline $\mathrm{M}$ & $\begin{array}{c}\mathbf{0 . 0 2 0 1 2 1} \\
(1.997050) * \\
\end{array}$ & $\begin{array}{c}0.019850 \\
(2.003755)^{* *}\end{array}$ & $\begin{array}{c}-0.010031 \\
(-0.852882) \\
\end{array}$ & $\begin{array}{c}-0.009899 \\
(-0.851493) \\
\end{array}$ & $\begin{array}{c}0.013327 \\
(0.200341) \\
\end{array}$ & $\begin{array}{c}0.014667 \\
(0.219165) \\
\end{array}$ & $\begin{array}{c}-0.023576 \\
(-0.757278) \\
\end{array}$ & $\begin{array}{c}-0.028899 \\
(-0.977426) \\
\end{array}$ \\
\hline INF & $\begin{array}{c}-0.003815 \\
(-4.636283)^{* * *}\end{array}$ & $\begin{array}{c}-0.003960 \\
(-4.597145)^{* *}\end{array}$ & $\begin{array}{c}-0.039697 \\
(-2.784845) * *\end{array}$ & $\begin{array}{c}-0.042748 \\
(-3.023324)^{* * *}\end{array}$ & $\begin{array}{c}-0.003087 \\
(-5.260851)^{* *}\end{array}$ & $\begin{array}{c}-0.002919 \\
(-4.988166)^{* *}\end{array}$ & $\begin{array}{c}-0.207149 \\
(-3.232067)^{* *}\end{array}$ & $\begin{array}{c}-0.218483 \\
(-3.708470) * *\end{array}$ \\
\hline OPEN & $\begin{array}{c}0.222104 \\
(3.600324) * *\end{array}$ & $\begin{array}{c}0.225274 \\
(3.609022)^{* *}\end{array}$ & $\begin{array}{c}0.220450 \\
(2.759543)^{* *}\end{array}$ & $\begin{array}{c}0.219091 \\
(2.715146)^{* *}\end{array}$ & $\begin{array}{c}0.385596 \\
(1.514547) \\
\end{array}$ & $\begin{array}{c}0.350659 \\
(1.356288) \\
\end{array}$ & $\begin{array}{c}0.345762 \\
(1.128444) \\
\end{array}$ & $\begin{array}{c}0.378363 \\
(1.403944) \\
\end{array}$ \\
\hline DM & & $\begin{array}{c}-1.489313 \\
(-2.506270)^{* *} \\
\end{array}$ & & $\begin{array}{c}-2.292483 \\
(-2.999936)^{* *}\end{array}$ & & $\begin{array}{c}1.459476 \\
(1.269431) \\
\end{array}$ & & $\begin{array}{c}-2.832519 \\
(-2.714765)^{* *}\end{array}$ \\
\hline $\begin{array}{c}\text { Adjusted } \\
\text { R-squared }\end{array}$ & 0.05 & 0.06 & 0.05 & 0.07 & 0.05 & 0.06 & 0.11 & 0.17 \\
\hline \multicolumn{9}{|c|}{ t-statistics in parentheses are White's heteroskedasticity-consistent t-statistics. ${ }^{* *} \mathrm{t}$ statistics significant at $1 \%$} \\
\hline \multicolumn{9}{|c|}{ The dependent variable is the growth rate of real gdp per capita } \\
\hline \multicolumn{9}{|c|}{ GDP(-1) is the initial level of real GDP } \\
\hline \multicolumn{9}{|c|}{ FR is the ratio of CB to DGDP (both numerator and denominator are in nominal values) } \\
\hline \multicolumn{9}{|c|}{$\mathrm{M}$ is the ratio of M2 to gdp (both numerator and denominator are in nominal values) } \\
\hline \multicolumn{9}{|c|}{ INF is the annual rate of increase in the GDP deflator } \\
\hline \multicolumn{9}{|c|}{ OPEN is the sum of lines $78 \mathrm{bed}$ and 78 bid from the IMF's IFS database } \\
\hline \multirow{2}{*}{\multicolumn{9}{|c|}{ DM is the dummy variable for excess money growth (measured as annual rates of growth of $10 \%$ or more) }} \\
\hline & & & & & & & & \\
\hline & & & & & & & & \\
\hline
\end{tabular}




\section{Appendix 3: Graphs Depicting the Effect of Official Dollarization on CB and FR (Cast Study: Argentina)}

CB (Sample period: 1990-2002)

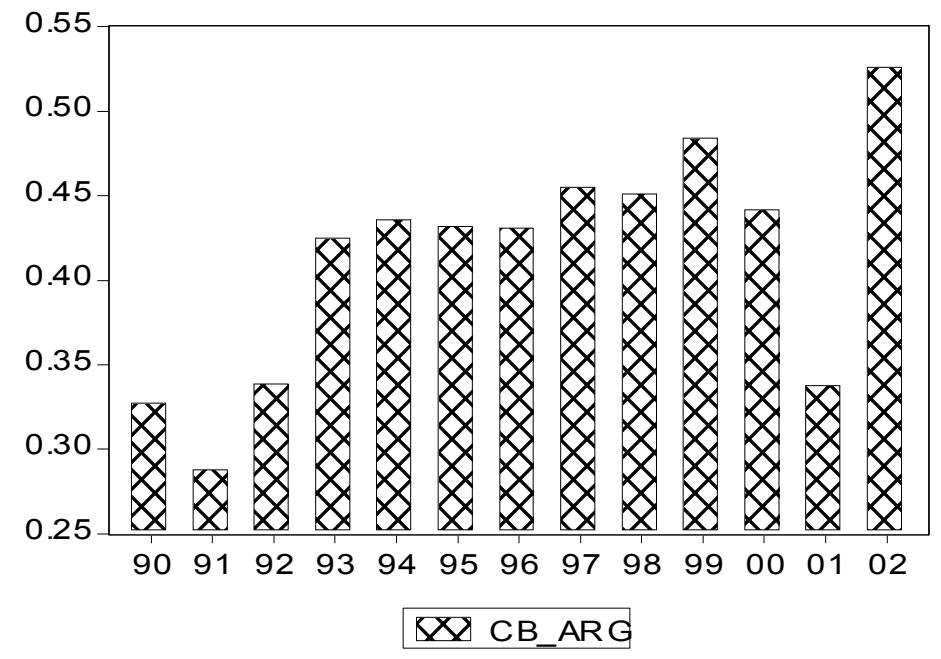

FR (Sample period: 1990-2002)

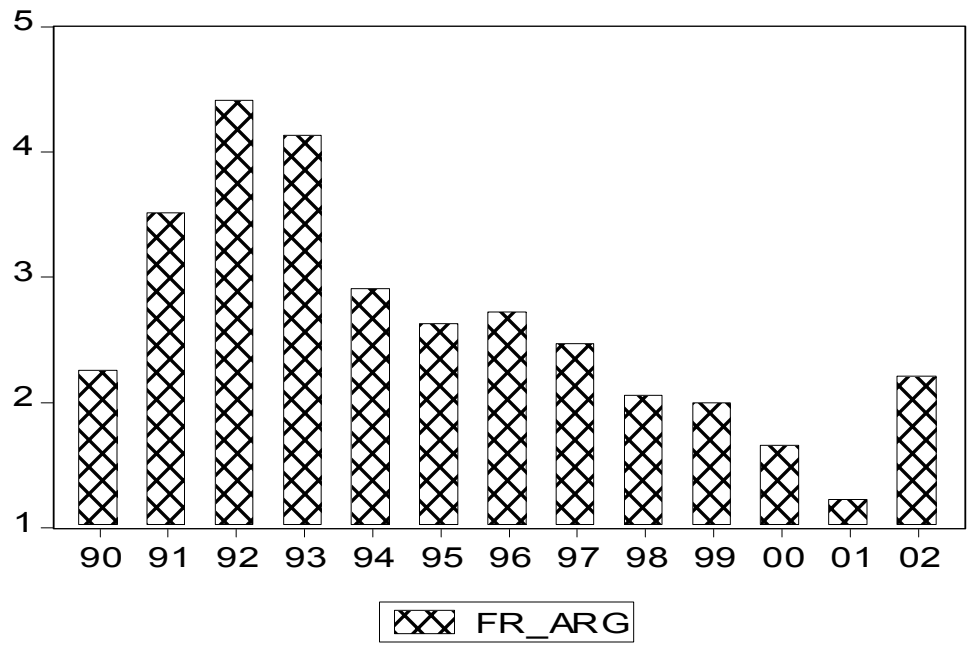

Both graphs above indicate that dollarization (start date measured as 1990 for the beginning of the official dollarization period in Argentina, have a marked effect on CB and FR. As expected, both variables increase dramatically after dollarization, indicating that $\mathrm{CB}$ can act as a good proxy to measure excessive dollarization. Excessive dollarization is also representative of financial repression, and the FR variable is able to capture this effect through its dramatic increase as seen above. 


\title{
Chapter 3
}

\section{The effect of financial integration on financial development and growth:}

\author{
A Case Study of the European Union
}

\begin{abstract}
While it is evident that the integration that European countries are involved in through the European Union (EU) is beneficial in terms of labour and trade opportunities, the effect of such integration on financial development is unclear. This paper implements an innovative approach that examines the impact of financial integration on financial development, and subsequently on economic growth within a sample of EU countries. Traditionally monetary depth measures are used to assess the size and development of the financial sector. However due to the centralized control of monetary policy, these monetary depth measures lose their effectiveness in assessing financial development within the EU. This paper therefore looks at bank-based measures of financial development in an effort to establish whether a relationship exists between financial development and growth in the European Union countries, and if so, whether this relationship has been affected by financial integration. The results support the hypothesis that the benefits of economic and financial integration are not uniform. Financial integration does not seem to have a very significant effect on growth where financial development has been controlled for.
\end{abstract}

\section{JEL Classification: F15, O11, 052}

Today's world is often described as the one of greater globalization and increased economic interaction between countries. The most advanced body of economically integrated states (the federally integrated states of the US not withstanding) in the world today is group of members of the European Union. While it is clear that economic integration can benefit member countries under certain circumstances, the effect of financial integration on financial development is not clear. This paper first tries to establish whether a relationship exists between financial integration and financial development in a specific group of European Union countries. In order to do this, bank based measures of financial development are used. Thereafter, the study is extended to look at the relationship between financial development and growth. The rest of this paper is organized as follows. Section 2 provides a brief history of the European Union; section 3 discusses the effect of integration on financial development and presents the theory behind financial development and its effect on growth and welfare; section 4 is the data and methodology section; sections 5 and 6 present the results and robustness checks; section 7 concludes.

Lillian Kamal, Department of Economics, West Virginia University, P.O. Box 6025, Morgantown, WV 26506.E-mail: ltkamal@mail.wvu.edu 


\section{I) A Brief History of the European Union}

The European Economic Community (EEC) was founded in the late 1950s, with the basic aim of realizing a customs union and a common agricultural market (Scheller, 2004). The founding members were France, W. Germany, the Netherlands, Belgium, Luxembourg, and Italy. The founding members did not at this time discuss monetary and financial integration. Moreover, they were all members of the well-functioning Bretton Woods system. By the end of the 1960s, the Bretton Woods system was undergoing considerable strain as a result of US Balance of Payments (BOP) policy. Inflationary differences between the EEC countries led to several BOP and exchange rate crises, which threatened to destroy the customs union. In 1969, the leaders of the founding member countries met at The Hague to draw up a plan for the creation of an economic and monetary union. The result was the Werner Report ${ }^{9}$, which laid out plans for the creation of an economic and monetary union in stages. In March 1979, the European Monetary System (EMS) was launched, which introduced the European Currency Unit (ECU), which was defined as a basket of fixed quantities of the member country currencies. The purpose of the ECU was to act as a unit of account to denominate operations in the intervention and credit mechanisms and as a reserve asset and a means of settlement among the member central banks. The EMS also covered the use of monetary and economic policies and tools for the achievement of exchange rate stability. The member countries were thus able to create a zone with increased monetary stability and relaxed capital controls. The constraints on exchange rate aided the member countries with high inflation problems in pursuing disinflation policies through monetary policy.

In 1989, Jacques Delors, President of the European Council, chaired a committee that recommended that economic and monetary union be achieved in three distinct steps:

1. Stage One would focus on completing the internal market by removing disparities between the member countries' economic policies.

2. Stage Two would set up the basic organs and institutions of the economic and monetary union.

3. Stage Three would involve the irrevocable locking together of the exchange rates.

The signing of the Treaty on European Unity (often referred to as "the Maastricht Treaty" on 7 February, 1992 ushered in a new era of irreversible movement towards the economic and monetary union (EMU). It is under this treaty that arrangements were made for the adoption of a common currency (later referred to as the "Euro") by January 1, 1999.

By 1992, the member countries were increased to Greece, UK, Ireland, Denmark, Spain and Portugal. The UK, Ireland and Denmark joined in 1973; Greece joined in 1981, and Spain and Portugal joined in 1986. In 1995, Austria, Finland and Sweden joined as well. As of 2004, ten more countries joined - these are Cyprus, the Czech Republic, Estonia, Hungary, Latvia, Lithuania, Malta, Poland, the Slovak Republic, and Slovenia. This brought the total EU membership to 25 countries.

\footnotetext{
${ }^{9}$ Named for Pierre Werner, the Prime Minister of Luxembourg, who chaired the committee.
} 


\section{II) Legislation on Banking in the European Union}

Initially the Community sought to establish a compulsory regulatory framework for all European banks. However, member states failed to agree on the content of the legislation. It was therefore decided the banking regulation, albeit with the ultimate aim of uniformity across the member states, would be implemented gradually. The crucial piece of regulation was The Second Banking Directive ${ }^{10}$ of December 1989 which allowed for the mutual recognition of banking licenses opening the way for cross-border banking operations (Hadjiemmanuil, 1996). These cross-border operations could take place simply by banks offering services to customers across the borders or by banks opening branches in other member countries. As long as banks had their home country authorization, they did not need any more authorization to compete in other member countries. Foreign banks (from other member countries) in the host country need only to follow their home country of origin regulation. There was one caveat however. All credit institutions within the Community had to observe a minimum of $8 \%$ of own funds to riskweighed assets. In May of 1994, the Deposit-Guarantee Directive came into effect. Under this Directive, banks in the Community had to offer a minimum level of protection for depositors' funds. Interestingly, the Community decided that the host country would provide the guarantee for depositors' funds, even if the banks were from other member countries. This discouraged the member countries from tolerating weak foreign banks within their borders (Hadjiemmanuil, 1996).

Other studies have been carried out that have looked at changes in the structure of European banks especially during the 1990s. An important outcome of the increased competition between banks in the Community has been the reduction in the number of banks, primarily through mergers and acquisitions (Ibanez and Molyneaux, 2002), resulting in an increase in the level of concentration in domestic bank industries. Ibanez and Molyneaux also find that the number of bank branches per capita also fell during the 1990s, except for three countries (Italy, Spain and Ireland) where the bank branch per capita ratio continued to increase until 1998.

\section{Theory}

The European Union countries display a great deal of diversity in terms of the degree of development and sophistication of financial markets (Guiso, et al., 2004). During the 1980-95 period, the ratio of stock market capitalization to gross domestic product ranged from 0.08 in Greece to 0.76 in the United Kingdom. Similarly the ratio of bank claims to gdp ranged from 0.5 in Italy to over 1 in Sweden and the Netherlands. This diversity in financial markets is considered an opportunity for lesser-developed financial markets, which are expected to accelerate in development as a result of financial and economic integration. It is therefore reasonable to expect that the lesser-developed countries among the EU group would experience greater positive effects from financial integration.

\footnotetext{
${ }^{10}$ The First Banking Directive was adopted in 1977 and it simply stated that if banks from one member state wished to operate in another member country (the host country) through a branch, the branch would eventually be exempt from the host country's regulations. (Hadjiemmanuil, 1996)
} 
A study of the effect of financial development on growth in EU countries must follow a two-stage procedure. It is first necessary to explore the effect of financial integration on financial development, and then relate these effects to growth.

\section{1) Financial Integration and Financial Development}

In the discussion that follows on the advantages of financial integration, the emphasis is placed on the effect of financial integration on the banking system. ${ }^{11}$ The basic argument in favour of financial openness is that it could lead to an increase in the size and depth of domestic financial markets and increase the degree of efficiency in financial intermediation by lowering costs, and also reducing the excessive profits associated with cartelized markets. This then leads to an increase in investment and improved resource allocation. Levine (1996) and Caprio and Honohan (1999) have argued that foreign bank penetration is beneficial to an economy and has the following effects:

- An improvement in the quality of financial services in the domestic country, by increasing competition and allowing for the adoption of more sophisticated banking techniques and technology (for example, more advanced risk-management systems). The adoption of such technologies improves efficiency, by reducing the cost of acquiring information about potential borrowers and the projects that the bank may choose to finance. Ultimately increased efficiency leads to a lower incidence of adverse selection.

- Increased access by the domestic country to international capital, either directly or indirectly, through parent banks.

- Increased stability of the domestic financial system (and reduced volatility of capital flows) if savers move funds (during times of financial instability) from domestic banks to foreign institutions (based within the domestic country), rather than engaging in international capital flights.

It has been argued that financial integration should increase the supply of finance to less financially developed countries in an economic grouping (Guiso, et al., 2004). Giannetti and Ongena (2005), explain that this can occur because of two reasons. More efficient financial intermediaries can gain a greater degree of access to financial markets in less financially developed markets either through increased facilitation of entry, or through the ability of these intermediaries to access proximally further markets. In both scenarios, firms in the less financially developed markets begin to enjoy easier and more cost-efficient access to sources of external finance in the broadly integrated area. This then has a positive effect on capital accumulation and eventually economic growth. Following is a more detailed discussion on these two channels of effect.

Financial integration implies that domestic financial markets begin to experience competition from more competitive external financial agents that are within the economic grouping but outside the boundaries of the domestic economy. This competitive pressure drives domestic financial markets to greater efficiency and to the extent that greater efficiency drives the demand for loanable funds, this should translate into an increased size of the financial sector in the domestic economies (Guiso, et al., 2004). In response to the foreign banks' competitive pressures, the domestic financial sector then reduces interest margins and thus profits to stay competitive (Giannetti and Ongena, 2005). This should then lead to an increased demand for funds by firms and this will then lead to an increase in the size of the formal financial sector. It is also expected that if boundaries on financial activity are lifted foreign more efficient financial agents will enter the domestic markets to provide financial services and in some cases may

\footnotetext{
${ }^{11}$ However, financial integration has been shown to affect consumption smoothing, domestic investment and is also thought to have to effects on macroeconomic discipline. For a discussion, see Agenor (2002).
} 
acquire local banks or merge with local banks (Giannetti, and Ongena 2005). The entry of these more efficient foreign agents erodes the profit margins of local banks, which must then engage in cost-cutting ventures to stay competitive. The reduction of costs streamlines the credit process resulting in a better flow of credit that theoretically goes on to positively impact investment and economic growth. It is therefore reasonable to expect the ratio of bank lending to gdp to increase as a result of financial integration.

Another positive effect of financial integration on domestic financial development occurs through the effects of legislation on the financial sector. Often financial integration involves the standardization of regulations on accounting standards, banking practices, bank supervision and corporate governance. Less financially developed economies then must conform to the regulatory standards followed by the more highly developed foreign financial markets. Ultimately this standardization of regulation may ease the adverse selection and moral hazard problems as the projects that are funded by financial intermediaries become subject to closer and more accepted forms of scrutiny.

\section{III) How Does an Efficient Financial System Influence Growth?}

In general, the literature has presented two channels through which each of these financial functions can affect economic growth - the capital accumulation channel and the technological innovation channel. A financial system will alter the rate of capital accumulation by affecting the rate of savings, or by reallocating savings among new and different capital producing technologies. The financial system will also affect the rate of technological innovation and through increased intermediation increase the level of investment in the economy (De Gregorio, 1999). Overall the development of the financial system affects investment in the following ways:

1. Improvements in the quality of investment: When financial institutions develop expertise in the evaluation and selection of projects (control of the adverse selection and moral hazard problems) the profitability of investment projects rises (Greenwood and Jovanovic, 1990). Greenwood and Jovanovic develop a model in which efficient intermediaries encourage high-yield investment and growth by pooling idiosyncratic investment risks.

2. An increased number of long-term projects: Typically long-term projects are high-risk, high-return projects and are found to be more productive. A liquid financial market encourages increased savings, which finance more of these high-risk, high-return projects (Diamond and Dybvig, 1983).

3. Portfolio Diversification: A well-developed financial system allows savers to share risks, and thus savers may be more willing to save in riskier projects, which stimulate specialization and allow for economies of scale (Saint-Paul, 1992, Kalemli-Ozcan, et al, 2001).

Surveys of the economic literature have found the relationship between finance and growth to be more strongly measured for developing countries; however the relationship is still under discussion in the case of developed countries especially when studied at the aggregate level ${ }^{12}$ (Thiel, 2001). The European Financial Round Table (quoted in Economic and Financial

\footnotetext{
${ }^{12}$ Firm level analyses, have however, found strong support that finance causes growth in industrial countries (see Thiel, 2001).
} 
Committee, 2002) commissioned a study that suggested that due to financial integration under the EU, growth rates could increase annually by up to $0.7 \%$.

Recent theoretical contributions have endogenized both financial intermediation and growth, and found bi-directional causality. ${ }^{13}$ In this kind of a framework, on the one hand, growth stimulates higher participation in financial markets and this aids in the creation and expansion of financial institutions. On the other hand, financial institutions become more efficient in project selection, and thus do away with the adverse selection problem, and this stimulates investment and growth.

Before any study on financial development can be embarked on, a key issue to address is the choice of proxy for financial development. The terms financial development is a term that includes several reforms in the financial system of an economy - these reforms include but are not limited to deregulation of financial markets, development of the banking sector, removal of government controls on interest rates and development of the stock market. It is then understandable why researchers have experienced problems in identifying one clear indicator of financial development.

\section{IV) Measurement of Financial Development}

One of the standard proxies in the literature is a form of monetary depth measure - this could be the ratio of narrow or broad money to GDP. King and Levine (1993a,b) who wrote the seminal papers in this area, indicate that different definitions monetary aggregates can represent different roles of financial intermediation. Some studies have used the ratio of M1 to GDP. The use of this measure is not without criticism though. The financial sector in an economy performs two main functions - it provides a conduit for funds from savers to borrowers, and provides liquidity to the economy. A high ratio of M1 to GDP indicates a high level of liquidity in the economy, and thus a high degree of monetization. However, as DeGregorio and Guidotti (1995) indicate, a high level of monetization may actually indicate a low level of financial development. They provide the example of the "monetary overhang" in Eastern Europe and the former Soviet Union where a lack of alternative assets led to a high level of money holdings in these economies. This is also related to the analysis by Bencivenga and Smith (1991) that indicates that financial repression may lead to an increase in the ratio of liquid assets to GDP. According to the analysis by DeGregorio and Guidotti, a low level of monetization may actually indicate an economy where there are many alternative assets that can serve as stores of value.

King and Levine (1993a,b) used monetary depth measures related to both M1 and M2. Traditionally, monetary depth measures reflect the formal size of the financial sector. Under conditions of economic integration, however, a common central bank is created. A common central bank means that monetary policy is no longer independent. Therefore if a monetary injection occurs, it is a decision that commonly affects all countries involved. Since monetary policy is no longer independent, the money supply in each of these countries is determined exogenously and may no longer be a very useful indicator of the size of the financial sector.

Moreover, as De Gregorio and Guidotti (1995) have pointed out, monetary depth measures are more related to the ability of financial systems to provide transaction services, as opposed to the ability of financial intermediaries to act as a link between borrowers and savers. Therefore, this paper does not use monetary depth measures as proxies for financial development. Some authors have experimented with using M3, which is also called liquid liabilities. ${ }^{14}$

DeGregorio and Guidotti suggest the use of the ratio of domestic credit to the private sector to GDP as a proxy for the degree of financial intermediation. This measure is indicative of the level of credit provided to the private sector by both the Central Bank and commercial banks.

\footnotetext{
${ }^{13}$ See for example Greenwood and Jovanovic, 1990.

${ }^{14}$ See for example Gelb (1989).
} 
It is advantageous to use this measure as a proxy for financial development, because it excludes credit provided to the public sector, and thus more accurately captures the funds that are channeled to the private sector. This then is one of the choice proxies in this paper.

\section{V) Financial Integration and Welfare}

A country's residents can adjust their portfolios in response to income fluctuations by buying and selling assets and lending on international credit markets, thus allowing for the smoothing of transitory shocks. Thus the concept of international risk sharing indicates that the similarity of shocks is not necessarily a pre-requisite for a common currency, as long as the members of the common-currency group are financially integrated. Thus countries could share a currency and be subjected to idiosyncratic shocks as long as they "insure" each other through private financial markets. (Mongelli, 2002)

Two channels of international risk sharing have been identified: the insurance channel and the credit channel (Asdrubali, et al, 1996). The insurance channel refers to countries holding claims against the output of other countries. The credit channel refers to countries borrowing from each other. Melitz and Zumer (1999) build on the paper by Asdrubali, et, al, (1996) by dividing the insurance channel into insurance through income flows and through depreciation. They find that capital gains and losses are of much greater importance for risk sharing between EU countries than income flows. They also find that openness promotes a greater degree of cross-ownership of resources and this is risk sharing through insurance rather than credit.

Some studies have suggested that financial integration must be very carefully managed so that benefits outweigh costs. Obstfeld (1994) argues that access to world capital markets allows countries to borrow in the face of adverse circumstances (thus allowing for consumption smoothing) and that potential growth and welfare gains from international risk sharing can be large. Obstfeld observes that if risky returns are relatively uncorrelated across countries, and provided that a certain level of risk free assets are held to begin with, a small rise in diversification will raise expected growth and increase national welfare. Devereaux and Smith (1994) develop a multi-economy model of diversification and growth and show that risk reduction associated with diversification may promote or retard growth with the outcome depending on assumptions about intertemporal consumption substitutability and the nature of uncertainty. It must be noted though that their model does not allow for aggregate shifts in the global portfolio of assets. These conclusions then suggest that international financial integration and subsequent diversification could lead to either higher or lower growth. An important quest in the literature has therefore been to identify policy prerequisites that allow countries to enjoy the gains of financial integration while minimizing the associated risks.

Theoretically the benefits of a diversified portfolio can be seen in the model developed by De Gregorio (1999) ${ }^{15}$. The basis for De Gregorio's model is the canonical case illustrated by Lucas (1987), which displays the reduction in the volatility of consumption through financial integration. Although the analysis by Lucas is primarily used to assess the benefits of stabilization policy, it can also be used to show the benefits of world trade in financial assets. This section of the literature is based on Cole and Obstfeld (1991) where it is assumed that output shocks affect not only consumption, but also the terms of trade between two countries is a twocountry model. Cole and Obstfeld find modest gains being realized from international portfolio diversification and this result has been offered as an explanation of the "home bias" puzzle, where savers tend to hold assets that are domestic based as opposed to international based.

\footnotetext{
${ }^{15}$ See Appendix A1 for a brief discussion of the model.
} 
It is often thought that the ultimate element of economic and financial integration is the introduction of the single currency. Karlinger (2002) suggests that the Euro is expected to increase competition for European banks by attracting new competitors from both inside and outside the EU. Karlinger also suggests that a change in consumer attitudes will allow savers and borrowers to meet directly in capital markets as opposed to banks. Evidence of this is seen in the relative increase in corporate bond issues, with issues increasing more than $400 \%$ (European Commission 2001). Not only did the number of bonds issued increase dramatically but the characteristics of the bonds issued also changed. It was not unusual to find bonds of 1-billionEuro denominations, while the rating of corporate bonds issued also fell somewhat. Studies have also found evidence that suggests that cross-border ownership of bonds increased (Field, et al, 2000).

\section{Sample Selection, Data and Methodology}

Since this study looks at the effects of financial integration on financial development and thereafter on growth, an adequate number of data points are required for the periods before and after economic integration. The data sources for this study are the IMF's International Financial Statistics and the World Bank's World Development Indicators. Not enough data is available for the pre-economic integration period from these sources for the founding members of the EU. Therefore the six founding members are dropped from the sample. The ten countries that joined in 2004 are dropped from the sample because not enough data is available for the post-economic integration period. The data set is then reduced to nine countries - Austria, Denmark, Finland, Greece, Ireland, Portugal, Spain, Sweden and the UK. Switzerland has never joined the European Union and is thus used as a control and for the purposes of identifying a secular trend.

De Gregorio (1999) applies a unique approach where he proposes that the effect of financial integration on financial development is the initial step to studying the effect of financial development on growth in an economically and financially integrated group of countries. His study however, is concentrated on developing countries. De Gregorio proposes the use of gross capital flows as a measure of financial integration - the basic logic is that the more financial integrated an economy, the more open it is to capital flows and so the greater the magnitude of gross capital flows between into and out of the country. The measure used here is based on De Gregorio's measure, but with a slight difference. In particular, a proxy was sought after that measured international savings and lending through the banking sector. The basic logic here is that the more financially integrated an economy, the more its banks are open to savers from outside the economy and the more opportunities it has for international lending. This measure of capital flows to the domestic banking sector is hereafter referred to as CAP. ${ }^{16}$

De Gregorio (1999) finds that financial integration positively and significantly affects the development of the financial system (which he measures through a variable called CREDIT that is similar to DCY). De Gregorio's other proxies of financial depth are stock market based. He uses a variable called MCAP (value of listed shares as a fraction of GDP), and TVT (total value of shares traded in a year relative to GDP). He finds that these depth measures are generally positively correlated with the degree of financial integration.

Following De Gregorio and Guidotti (1995), one of the proxies chosen is the ratio of private sector credit to GDP (hereafter identified as PCY). Total bank lending (identified

\footnotetext{
${ }^{16}$ Line 78 bhd and line 78 bid in the IFS data set. These series contain all financial transactions not covered in direct investment, portfolio investment, financial derivatives or reserve assets. Major categories within these series are deposits and loans (Source: IMF IFS guide).
} 
hereafter as domestic credit relative to GDP or DCY) is also related to the functionality of the financial sector and is therefore also used as a proxy for financial development (following De Gregorio, 1999). DCY includes both PCY and credit extended by the banking sector to the public sector - it is therefore expected that there will be a very high positive correlation between DCY and PCY. Finally, a third proxy is developed that looks at the receiving end of the banking sector. This proxy measures total deposits (checking, time and savings) within the banking sector. This proxy is hereafter identified as DGDP. All the above proxies are in nominal values and are measured relative to nominal gdp.

The methodology in this paper is as follows: for each country in the sample set, the above financial development ratios are calculated for the sample period: 19502000 . This section includes some statistics on these ratios. OLS regressions are run for each country using two sets of data points - one set pertaining to the period before the country joined the union and the other set for the period after the country joined the union. These regressions serve to test whether the relationship between financial development and growth has changed for individual countries. The sample set of nine countries is then compared with a European country that has not joined the union - Switzerland. Switzerland serves as a control for this experiment - since this country has not joined the union, it becomes interesting to see whether financial development measures in Switzerland have behaved in a manner similar to those in the other six countries.

Several panel regressions are also performed to test for overall effects. The panel regressions serve to establish whether the general nature of the relationship between (i) financial integration and financial development and (ii) financial development and growth was impacted by free banking across borders. A pool dummy variable is constructed that captures the date of accession.

Three main hypotheses are tested. First it is expected that financial integration will lead to an increase in the size of the financial sector ${ }^{17}$. An increase in the functionality of the financial sector should lead to an increase in the levels of DCY and PCY in the sample countries. Thus it is expected that economic integration (and thus financial integration) will positively impact financial development. Secondly, although, there is considerable diversity within the EU, it is expected that financial development post-accession will positively impact growth in the sample countries, although the magnitude of effect is certainly expected to differ. The final hypothesis is based on De Gregorio (1999), who finds that there is no evidence of a direct effect of financial integration on economic growth, after controlling for financial depth. He therefore concludes that the benefits of financial integration on economic growth arise primarily through the development of the financial system, and not through financial integration itself. The third hypothesis then is that the same effect will show in the EU sample - the effect of financial integration on growth will arise indirectly through the financial development channel, and not directly. This then implies that when financial integration is controlled for when testing for the effects of financial development on growth, the coefficient on financial integration should be insignificant.

\section{1) Data Statistics}

The table below displays some summary characteristics for the proxies for before and after accession to the EU. In order to capture the effects of EU accession and control for changes in general trends across Western Europe, each proxy is calculated relative to the proxy measure for Switzerland. The statistics below reflect the changes in the average values of these relative proxies before and after the date the country joined the EU.

\footnotetext{
${ }^{17}$ See Guiso et al. (2004) as mentioned in section 3A.
} 
Table 1: Averaged Proxy Measures Pre and Post Accession

\begin{tabular}{|l|l|l|l|l|l|l|l|l|l|}
\hline Country & Denmark & Ireland & UK \\
$(1973)$ & $(1973)$ & $(1973)$ & $\begin{array}{l}\text { Greece } \\
(1981)\end{array}$ & $\begin{array}{l}\text { Spain } \\
(1986)\end{array}$ & $\begin{array}{l}\text { Portugal } \\
(1986)\end{array}$ & $\begin{array}{l}\text { Austria } \\
(1995)\end{array}$ & $\begin{array}{l}\text { Finland } \\
(1995)\end{array}$ & $\begin{array}{l}\text { Sweden } \\
(1995)\end{array}$ \\
\hline DCY & 0.447 & 0.268 & 0.436 & $\mathbf{0 . 2 5 4}$ & 0.641 & 0.639 & 0.508 & 0.378 & 0.442 \\
\hline DCY & 0.395 & 0.391 & 0.535 & $\mathbf{0 . 5 6 3}$ & 0.619 & 0.523 & 0.725 & 0.333 & 0.271 \\
\hline PCY & 0.441 & 0.305 & $\mathbf{0 . 1 6 9}$ & 0.186 & 0.524 & 0.609 & 0.467 & 0.418 & 0.377 \\
\hline PCY & 0.353 & 0.389 & $\mathbf{0 . 5 1 7}$ & 0.265 & 0.501 & 0.439 & 0.598 & 0.339 & 0.233 \\
\hline DGDP & 0.303 & 0.620 & 0.389 & $\mathbf{0 . 2 2 4}$ & 0.667 & 0.704 & 0.551 & 0.438 & 0.557 \\
\hline DGDP & 0.404 & 0.517 & 0.536 & $\mathbf{0 . 5 1 7}$ & 0.563 & 0.769 & 0.659 & 0.381 & 0.348 \\
\hline
\end{tabular}

An immediate observation is that the ratios are not proximate to 1 and are in fact mostly well below 1. This indicates that Swiss levels of domestic and private sector credit are well above those of the EU countries within the sample. The last two rows of the table above show the ratio of deposits to GDP. Switzerland is well known as an international savings location, and so it is not unexpected that the values in the table are relatively low for this variable. Some of the statistics above stand out in terms of their constancy before and after EU accession. Compared to Switzerland, countries like Ireland, Spain, and Finland have been relatively stable in terms of the levels of domestic credit, private sector credit and total bank lending relative to GDP. If the ratios of financial development are taken to reflect an increasing financial sector through their increase in magnitude, it would indicate that there is relatively little increase in the size of the financial sectors in these three countries.

A few countries have displayed reductions in the relative values of the three proxies. For example, Denmark, Finland and Sweden display reductions in average DCY and PCY values before and after accession. Spain, Finland and Sweden show decreases in DGDP ratios before and after their accession dates.

Not all the ratios are relatively constant. For the UK, for example, the ratio of private sector credit to gdp increased more than $300 \%$ after economic integration. In Greece, the average relative DCY ratio was 0.254 before integration, but that ratio increased to 0.563 after economic integration. There was also a significant rise in DGDP in Greece (0.224 to 0.517$)$.

The hypothesis that financial integration should cause an increase in the size of the financial sector does not hold with respect to all the countries, if one is analyzing the relative proxy values over the region. In fact, the results are rather mixed - some countries have shown negative growth in the relative sizes of their financial sectors, while others have shown relatively high increases. 
Table 2: Correlations Between Proxies Post Accession

\begin{tabular}{|l|l|l|l|}
\hline & $D C Y$ & $P C Y$ & $D G D P$ \\
\hline \hline$D C Y$ & 1.0000 & $\mathbf{0 . 9 0 2 9 3 8}$ & $\mathbf{0 . 6 7 7 9 7 1}$ \\
\hline \hline$P C Y$ & & 1.0000 & $\mathbf{0 . 6 6 9 1 5 9}$ \\
\hline$D G D P$ & & & 1.0000 \\
\hline
\end{tabular}

Table 2 above displays the cross-correlations for the three proxies for financial development averaged out over the nine countries. As expected all correlations are positive and the highest correlation is between PCY and DCY, because PCY is in fact a component of DCY.

\section{II) The Model}

The panel approach is first discussed here because the individual OLS regressions are based on the general panel approach in the literature. Using OLS on pool data has been shown in the literature to be a good way to get first pass point estimates. Phillips and Moon (1999) and Pedroni (2000) have shown that OLS estimators are consistent with pool data. As N (the number of cross-sectional units) increases, however, the residual asymptotic bias increases.

The standard approach in the literature is to use a panel regression of the form based on Barro (1991):

$$
X_{i t}=\alpha F D_{i t}+\beta Z_{i t}+\mu_{i t}
$$

$\mathrm{X}$ represents the growth of per capita real GDP (this factor could also be a measure of the total factor productivity growth) in country $i$ at time t. FD is a variable that represents financial development. This variable is consecutively set to reflect the three proxies - DCY, PCY, and DGDP.

$\mathrm{Z}$ is a vector of conditioning variables, and usually includes other factors that theoretically affect economic growth. One of the factors in the set of $\mathrm{Z}$ may be the $\log$ of initial real GDP. This factor measures the convergence effect. The literature has included such variables as the log of initial higher education enrollment as a measure of human capital, and the population growth rate. Other factors that are sometimes included here include the inflation rate, an export and import to real GDP ratio factor (to measure openness), etc. In the case of this paper, the set of $Z$ is restricted to three variables - the log of initial GDP per capita, INIT, the degree of openness of the economy, OP, and a measure of inflation, INF. INIT measures the convergence effect over time. OP (measured as the ratio of the sum of exports and imports to gdp) captures the trade impact of the economic union. INF is the percentage change in the annual GDP deflator.

Macroeconomic conditions are expected to affect the development of the financial system (De Gregorio, 1999). Even at shorter horizons, high inflation can negatively impact the development of the financial system because of uncertainties in future financial conditions. It is possible though, that as a result of an inflationary environment, shorter-term instruments and 
inflation-indexed instruments could dominate the use of long-term contracts. Although the overall net effect on the financial sector is unclear, it is expected that high inflation would shift the focus of the financial sector towards short-maturity instruments (De Gregorio, 1999).

An open economy displays characteristics of trade openness as well as financial integration. The purpose of including the trade variable in the above formulation is to capture the effects of financial services involved in international transactions that may promote the development of the financial system.

In this paper, the basic theoretical approach is run using a fixed-effects methodology to control for country-specific effects. Equation (1) is then transformed to equation (2) below.

$$
X_{i t}=\eta_{i}+\alpha F D_{i t}+\beta Z_{i t}+\mu_{i t}
$$

where $\eta_{i}$ are country-specific constants. A priori the null hypothesis is that financial development will positively affect growth, and so the null hypothesis is that $\alpha>0$. Following De Gregorio (1999) and to isolate the effects of financial integration and financial development on growth, the above panel approach is extended to equation 2' below.

$$
X_{i t}=\eta_{i}+\alpha F D_{i t}+\delta F I_{i t}+\beta Z_{i t}+\mu_{i t}
$$

Following De Gregorio, who shows that the effects of financial integration are indirect on growth through the financial development channel, it is expected that $\delta$ will turn out to be insignificant (especially since openness will already be controlled for in the $\mathrm{Z}$ vector) while, $\alpha>0$. Furthermore, the above equation is also extended (equation 2" below) to include a dummy variable that controls for the date of accession for the different member countries in the sample. The dummy variable presents a simplistic way to capture not only financial integration but also economic integration, apart from pure openness (which is controlled for in the $\mathrm{Z}$ vector). If the dummy variable captures the same effect as the financial development variable, then it is expected a priori that $\gamma$ will be insignificant.

$$
\begin{aligned}
& X_{i t}=\eta_{i}+\alpha F D_{i t}+\gamma D_{i t}+\beta Z_{i t}+\mu_{i t} \\
& X_{i t}=\eta_{i}+\gamma F I_{i t}+\beta Z_{i t}+\mu_{i t}
\end{aligned}
$$

Equation 2", above includes only the financial integration variable without the financial development proxy in place. This particular specification attempts to capture the pure effects of financial integration on growth and relates to the third hypothesis being tested in this paper. Does financial integration affect growth independently of the financial development? A priori, it is 
expected that $\gamma$ will not be significant since the effects of financial integration are not expected to be direct on growth, but rather should affect growth indirectly through financial development.

Finally the panel regression is run with only the financial integration variable and the dummy variable alone as follows:

$$
X_{i t}=\eta_{i}+\delta F I_{i t}+\gamma D_{i t}+\beta Z_{i t}+\mu_{i t}
$$

If the dummy variable is successful at capturing similar effects on growth as the financial integration variable, it is expected that it will be insignificant in both equations 2 " and 2 ", , above.

Following De Gregorio, a two-stage procedure is performed where first the impact of financial integration on financial development must be examined. The basic panel formulation above is then expanded to include the following nested regression:

$$
F D_{i t}=\eta_{i}+\delta F I_{i t}+\beta Z_{i t}+v_{i t}
$$

where FI is a measure of financial integration and $\mathrm{Z}$ is a set of other variables that may be thought to affect financial development. These variables are set to be the same set of $Z$ as in equation (3). A priori, (following De Gregorio's finding) it is expected that $\delta>0$. Similar to the previous analysis, an extended version of equation 3 above is tested - this is equation 3' below that explicitly includes both the CAP variable and the D variable. In equation 3' below, it is expected that since financial integration is expected to affect financial development positively, and if the dummy variable is able to capture the same effects as the FI variable (when $\mathrm{Z}$ has controlled for openness), $\gamma$ will be insignificant.

$$
F D_{i t}=\eta_{i}+\delta F I_{i t}+\gamma D_{i t}+\beta Z_{i t}+v_{i t}
$$

It is expected that with a diverse group of countries such as the EU countries, a panel regression approach may not be adequate in capturing the differences in the relationship between FD and growth, and FI and FD. Therefore, only part of the focus of this paper is on overall panel effects, the analysis is also extended to study the relationships within the various countries in the sample. The basic regression is adapted to the individual country approach by transforming it into a linear regression of the following form.

$$
X_{t}=\alpha+\beta F D_{t}+\gamma Z_{t}+v_{t}
$$

where $\mathrm{X}$ represents the growth rate of real GDP in country $i$, FD represents a measure of financial development for country $i$, and $\mathrm{Z}$ is a set of other variables that affect growth (set to be the same as the panel regression vector of $Z$ ). 
Similar to the panel approach, a two-stage procedure is followed where first the impact of financial integration on financial development must be examined. The linear equation above is then expanded to include the following nested regression

$$
F D_{t}=\phi+\delta F I_{t}+\beta Z_{t}+v_{t}
$$

where FI is a measure of financial integration and $\mathrm{Z}$ is a set of other variables that may be thought to affect financial development. These variables are set to be the same set of $Z$ as in equation (8).

\section{Results}

Table 3 presents the results from the panel regressions on equations 2-2"'. The table is separated into three panels by proxy for financial development. Some startling conclusions can be made from the analysis. Financial development is always negative in effect on growth, regardless of the proxy being used. The coefficients on the financial development proxies are largely significant and always negative. When tested along with financial development, the financial integration variable is always positive in effect, although insignificant. The set of conditioning variables $\mathrm{Z}$ behaves as expected. Openness has a positive effect on growth and inflation has a negative effect on growth. It is quite obvious that the dummy variable for integration is capturing a different effect from the CAP variable. The coefficient on the dummy is always negative, and moreover it is significant in the cases of PCY and DGDP. Thus international savings and loans through the banking sector are not captured adequately by a simple dummy variable and must be controlled for on their own.

The results seem to indicate that overall financial development has not benefited growth. This may of course reflect the choice of proxy involved. However, it is more likely, as expected that a pool analysis which may show the overall effect across a group of countries may not adequately capture the individual country effects of financial development on growth. The EU countries are a diverse group and financial development is expected to have a strongly positive impact on growth in the lesser developed countries in the sample. This analysis is left for further discussion after the results from the individual country regressions are presented. 


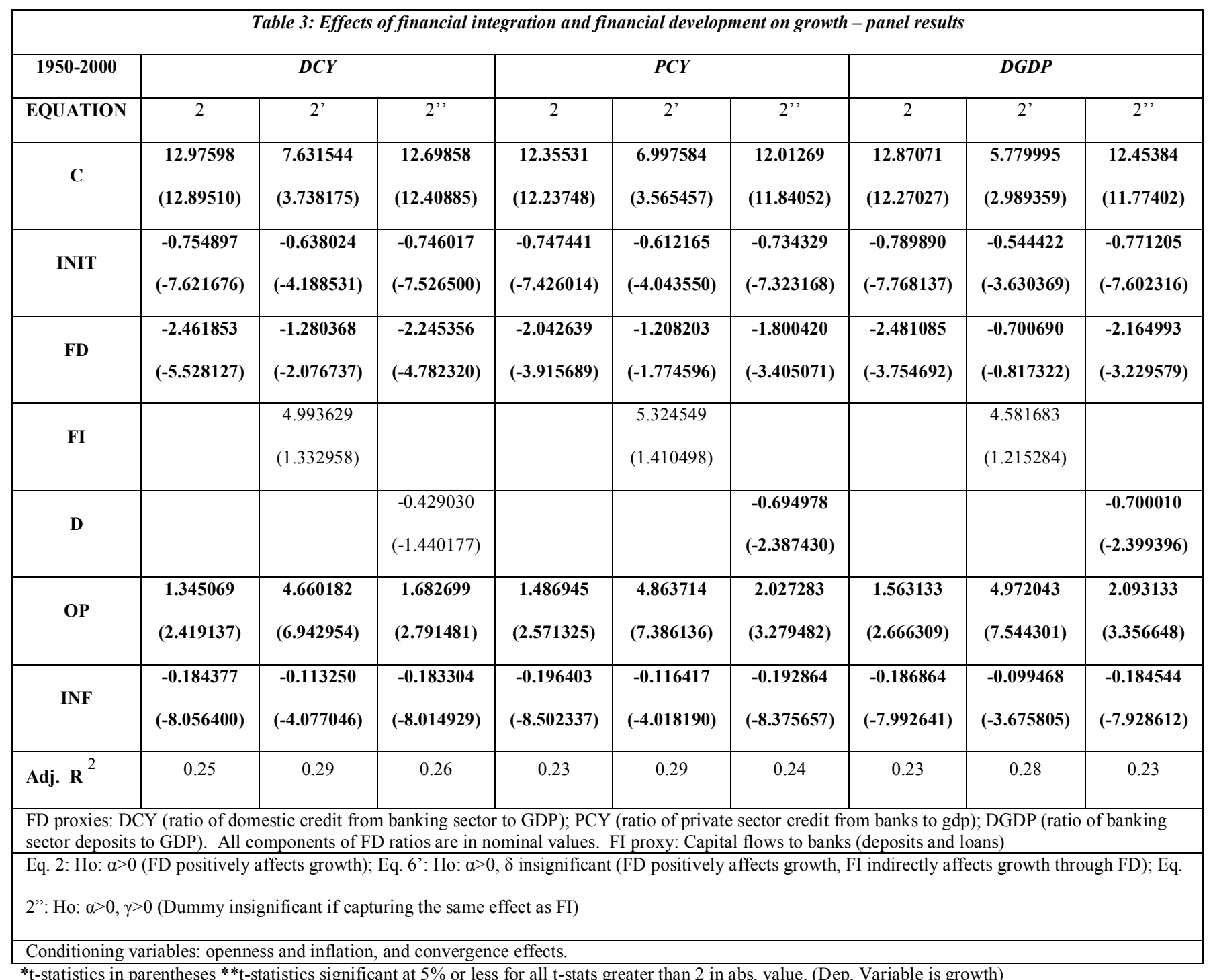

Conditioning variables: openness and inflation, and convergence effects.

${ }^{*}$ t-statistics in parentheses $* *$ t-statistics significant at $5 \%$ or less for all t-stats greater than 2 in abs. value. (Dep. Variable is growth) 
Table 4 below presents the results from equations 2",' and 2,",'. These equations serve to isolate the effects of financial integration on growth without the use of the financial development variables. Earlier results already indicate that the CAP and D variables are not comparable in effect, and seem to be reflecting different effects on growth. The results indicate that as in Table 3, financial integration appears to have a positive effect on growth, but the coefficients are not significant. When the $\mathrm{D}$ variable is included, the magnitude of the coefficient on CAP decreases only slightly and D is insignificant. However, interestingly without the inclusion of the FD proxies, the $\mathrm{D}$ variable now registers a positive effect.

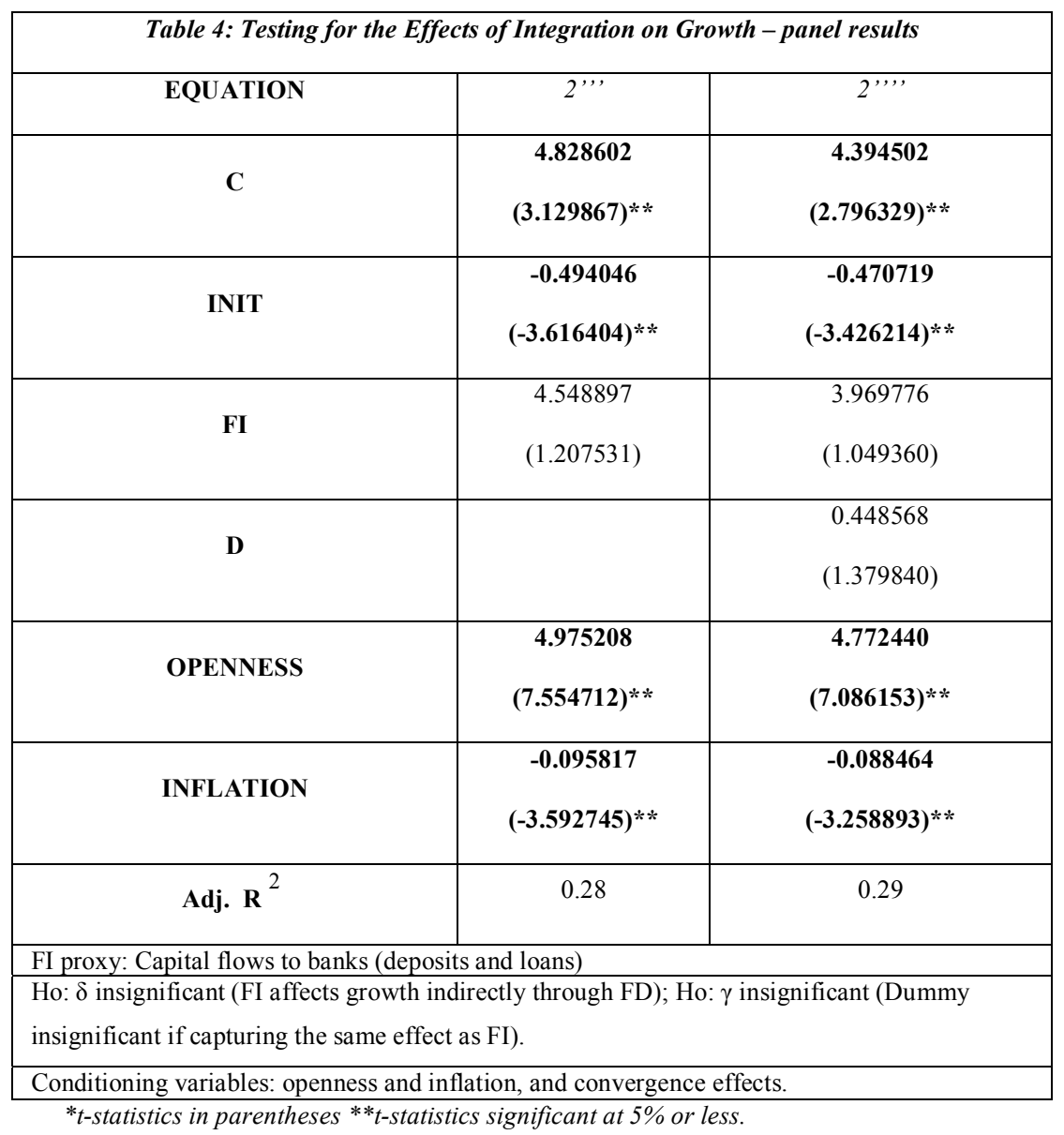




\begin{tabular}{|c|c|c|c|c|c|c|}
\hline \multicolumn{7}{|c|}{ Table 5: Testing for the effects of financial integration on financial development-panel results } \\
\hline 1950-2000 & \multicolumn{2}{|c|}{$\overline{D C Y}$} & \multicolumn{2}{|c|}{$P C Y$} & \multicolumn{2}{|c|}{ DGDP } \\
\hline EQUATION & 3 & 3 ' & 3 & 3 ' & 3 & 3 \\
\hline $\mathbf{C}$ & $\begin{array}{l}2.189169 \\
(13.33441)\end{array}$ & $\begin{array}{l}2.225052 \\
(13.28282)\end{array}$ & $\begin{array}{c}1.795213 \\
(12.04501)\end{array}$ & $\begin{array}{l}1.896579 \\
(12.75262)\end{array}$ & $\begin{array}{l}1.357796 \\
(11.40969)\end{array}$ & $\begin{array}{l}1.399179 \\
(11.56765)\end{array}$ \\
\hline INIT & $\begin{array}{l}-0.112450 \\
(-7.735001)\end{array}$ & $\begin{array}{l}-0.114379 \\
(-7.810313)\end{array}$ & $\begin{array}{c}-0.097765 \\
(-7.407614)\end{array}$ & $\begin{array}{l}-0.103212 \\
(-7.938356)\end{array}$ & $\begin{array}{l}-0.071895 \\
(-6.822450)\end{array}$ & $\begin{array}{l}-0.074118 \\
(-7.009236)\end{array}$ \\
\hline FI & $\begin{array}{l}0.347347 \\
(0.866454)\end{array}$ & $\begin{array}{l}0.395217 \\
(0.980089)\end{array}$ & $\begin{array}{l}0.641988 \\
(1.764029)\end{array}$ & $\begin{array}{l}0.777218 \\
(2.170956)\end{array}$ & $\begin{array}{l}0.046791 \\
(0.161024)\end{array}$ & $\begin{array}{c}0.101999 \\
(0.350307)\end{array}$ \\
\hline D & & $\begin{array}{c}-0.037078 \\
(-1.070022)\end{array}$ & & $\begin{array}{c}-0.104745 \\
(-3.404728)\end{array}$ & & $\begin{array}{l}-0.042762 \\
(-1.709054)\end{array}$ \\
\hline $\begin{array}{l}\text { OPEN- } \\
\text { NESS }\end{array}$ & $\begin{array}{c}-0.246043 \\
(-3.510814)\end{array}$ & $\begin{array}{l}-0.229283 \\
(-3.193836)\end{array}$ & $\begin{array}{l}-0.092281 \\
(-1.450462)\end{array}$ & $\begin{array}{c}-0.044933 \\
(-0.704994)\end{array}$ & $\begin{array}{l}-0.004517 \\
(-0.088921)\end{array}$ & $\begin{array}{c}0.014813 \\
(0.285762)\end{array}$ \\
\hline $\begin{array}{l}\text { INFLA- } \\
\text { TION }\end{array}$ & $\begin{array}{l}-0.013616 \\
(-4.797577)\end{array}$ & $\begin{array}{l}-0.014224 \\
(-4.915771)\end{array}$ & $\begin{array}{l}-0.017050 \\
(-6.617475)\end{array}$ & $\begin{array}{l}-0.018767 \\
(-7.305476)\end{array}$ & $\begin{array}{c}-0.005210 \\
(-2.532631)\end{array}$ & $\begin{array}{c}-0.005911 \\
(-2.829257)\end{array}$ \\
\hline Adj. $\mathbf{R}^{2}$ & 0.24 & 0.25 & 0.24 & 0.28 & 0.17 & 0.18 \\
\hline $\begin{array}{l}\text { FI proxy: Capi } \\
\text { Ho: } \delta>0 \text { (FI po } \\
\text { as FI). }\end{array}$ & $\begin{array}{l}\text { l flows to ban } \\
\text { itively affects }\end{array}$ & $\frac{\text { s (deposits and }}{\text { D); Ho: } \gamma \text { insig }}$ & $\begin{array}{l}\text { loans) } \\
\text { ificant (Dumr }\end{array}$ & y insignificant & f capturing the & ame effects \\
\hline
\end{tabular}

Table 5 above displays the results of the nested regressions 3 and 3'. The purpose of the exercise was to capture the interaction between financial integration and financial development. The CAP variable is always positive indicating that financial integration has a positive effect on financial development. When the dummy in included in formulation 3', the CAP variable is significantly positive in its effect on PCY. The conditioning variable for openness is negatively in its effect on FD - this may be indicative of trade-related financial transactions that do not have beneficial effects on the banking sectors of the pool group. The above panel results (Table 3-5) paint an overwhelmingly negative role for financial development in explaining growth. It would not be surprising for this analysis to change when the focus changes to country-specific studies. 
Table 6: Financial Integration and Financial Development Post Accession

\begin{tabular}{|c|l|l|l|l|l|l|}
\hline \multicolumn{7}{|c|}{ Financial Integration and Financial Development } \\
\hline & DENMARK & GREECE & $\begin{array}{l}\text { IRELAND } \\
\text { Post-1975 }\end{array}$ & $\begin{array}{l}\text { PORTUGAL } \\
\text { Post-1986 }\end{array}$ & $\begin{array}{l}\text { SPAIN } \\
\text { Post-1986 }\end{array}$ & $\begin{array}{l}\text { UK } \\
\text { Post-1975 }\end{array}$ \\
& Post-1975 & Post 1981 & Post 1925 \\
$D C Y$ & 0.336622 & 0.612872 & 0.471068 & 1.616718 & $\mathbf{0 . 5 8 3 0 3 8}$ & 0.443225 \\
& $(0.469142)$ & $(0.550544)$ & $(1.083989)$ & $(1.887884)$ & $\mathbf{( 3 . 0 9 5 3 2 5 ) * *}$ & $(0.601513)$ \\
& 0.41 & 0.13 & 0.73 & 0.28 & $\mathbf{0 . 3 5}$ & 0.89 \\
\hline PCY & 0.555998 & 0.380125 & 0.291879 & 2.052962 & 0.456659 & 0.394515 \\
& $(0.602939)$ & $(1.162105)$ & $(1.121463)$ & $(1.894507)$ & $(1.300830)$ & $(0.575560)$ \\
& 0.10 & 0.79 & 0.88 & 0.54 & 0.25 & 0.92 \\
\hline DGDP & $\mathbf{- 0 . 6 6 6 8 0 0}$ & -0.247658 & -0.055221 & 0.362501 & -0.199358 & -0.353375 \\
& $\mathbf{( - 2 . 9 1 5 1 7 8 ) * *}$ & $(-0.412156)$ & $(-0.217646)$ & $(1.207679)$ & $(-1.164067)$ & $(-0.543729)$ \\
& $\mathbf{0 . 8 6}$ & 0.02 & 0.81 & 0.56 & 0.45 & 0.84 \\
\hline
\end{tabular}

*t-statistics significant at $5 \%$ or less. Adjusted R-squared values below t-stats. Dep. Variable is FD. Ho: FI significant in explaining FD

Table 6 above shows the results of regressing the financial integration variable (CAP) on the financial development indicators after the member countries joined the EU. Several findings are immediately apparent. Only in two cases, is financial integration important in explaining the path of financial development. Financial integration has a significantly negative effect on DGDP in Denmark, and it has a significantly positive effect on financial development in Spain. It is also very interesting to note that in five out of the six countries in Table 6, CAP has a negative relationship with DGDP (significant only in Denmark). These results become doubly interesting when compared with the results when financial development is subsequently regressed on growth. 


\section{Table 7}

This table shows the results of the OLS regressions on each of the six countries.

\section{Linear regressions coefficients for financial development proxies (European Union countries based on date of accession)}

\begin{tabular}{|c|c|c|c|c|c|c|}
\hline & \multicolumn{2}{|c|}{ DCY } & \multicolumn{2}{|c|}{ PCY } & \multicolumn{2}{|c|}{ DGDP } \\
\hline \multirow{3}{*}{ AUSTRIA } & \multicolumn{2}{|c|}{ Pre and post 1995} & \multicolumn{2}{|c|}{ Pre and post 1995} & \multicolumn{2}{|c|}{ Pre and post 1995} \\
\hline & $\begin{array}{c}-9.412940 \\
(-2.436934)^{* * *} \\
0.25\end{array}$ & $\begin{array}{c}-27.94826 \\
(-0.318484) \\
0.09\end{array}$ & $\begin{array}{c}-15.82831 \\
(-2.692623)^{* * *} \\
0.27\end{array}$ & $\begin{array}{c}-18.75111 \\
(-0.952870) \\
0.07\end{array}$ & $\begin{array}{c}-12.56564 \\
(-2.295781)^{* *} \\
0.23\end{array}$ & $\begin{array}{c}289.1119 \\
(1.934169) \\
0.29\end{array}$ \\
\hline & \multicolumn{2}{|c|}{ Pre and post 1973} & \multicolumn{2}{|c|}{ Pre and post 1973} & \multicolumn{2}{|c|}{ Pre and post 1973} \\
\hline \multirow[t]{2}{*}{ DENMARK } & $\begin{array}{c}-5.427312 \\
(-0.221548) \\
0.18\end{array}$ & $\begin{array}{c}2.019721 \\
(0.784835) \\
0.24\end{array}$ & $\begin{array}{c}-13.19634 \\
(-0.601038) \\
0.36\end{array}$ & $\begin{array}{c}1.523668 \\
(0.761510) \\
0.24\end{array}$ & $\begin{array}{c}-1.008557 \\
(-0.025842) \\
0.15\end{array}$ & $\begin{array}{c}-18.71513 \\
(-3.264076)^{* * *} \\
0.47\end{array}$ \\
\hline & \multicolumn{2}{|c|}{ Pre and post 1995} & \multicolumn{2}{|c|}{ Pre and post 1995} & \multicolumn{2}{|c|}{ Pre and post 1995} \\
\hline \multirow[t]{2}{*}{ FINLAND } & $\begin{array}{c}-23.18395 \\
(-3.311204)^{* *} \\
0.33\end{array}$ & $\begin{array}{c}\text { 36.83252 } \\
(3.558947) * * \\
0.93\end{array}$ & $\begin{array}{c}-20.43890 \\
(-2.556896)^{* *} \\
0.27\end{array}$ & $\begin{array}{c}55.16419 \\
(2.830417)^{* *} \\
0.90\end{array}$ & $\begin{array}{c}-10.00599 \\
(-0.682867) \\
0.15\end{array}$ & $\begin{array}{c}34.93613 \\
(0.932001) \\
0.50\end{array}$ \\
\hline & \multicolumn{2}{|c|}{ Pre and post 1981} & \multicolumn{2}{|c|}{ Pre and post 1981} & \multicolumn{2}{|c|}{ Pre and post 1981} \\
\hline \multirow[t]{2}{*}{ GREECE } & $\begin{array}{c}4.121551 \\
(0.613698) \\
0.32\end{array}$ & $\begin{array}{c}-4.226907 \\
(-0.697950) \\
0.21\end{array}$ & $\begin{array}{c}7.048049 \\
(0.707305) \\
0.33\end{array}$ & $\begin{array}{c}14.84755 \\
(0.746299) \\
0.21\end{array}$ & $\begin{array}{c}8.231232 \\
(0.818104) \\
0.33\end{array}$ & $\begin{array}{c}12.73417 \\
(1.161000) \\
0.25\end{array}$ \\
\hline & \multicolumn{2}{|c|}{ Pre and post 1973} & \multicolumn{2}{|c|}{ Pre and post 1973} & \multicolumn{2}{|c|}{ Pre and post 1973} \\
\hline \multirow[t]{2}{*}{ IRELAND } & $\begin{array}{c}11.04068 \\
(0.988393) \\
0.12\end{array}$ & $\begin{array}{c}-0.290925 \\
(-0.049587) \\
0.35\end{array}$ & $\begin{array}{c}16.03686 \\
(0.872708) \\
0.13\end{array}$ & $\begin{array}{c}18.19216 \\
(2.392245)^{* * *} \\
0.48\end{array}$ & $\begin{array}{c}5.559172 \\
(0.373449) \\
0.17\end{array}$ & $\begin{array}{c}18.65874 \\
(3.140483)^{* *} \\
0.55\end{array}$ \\
\hline & \multicolumn{2}{|c|}{ Pre and post 1986} & \multicolumn{2}{|c|}{ Pre and post 1986} & \multicolumn{2}{|c|}{ Pre and post 1986} \\
\hline \multirow[t]{2}{*}{ PORTUGAL } & $\begin{array}{c}-9.333515 \\
(-1.356582) \\
0.45\end{array}$ & $\begin{array}{c}4.090554 \\
(1.619589) \\
0.88\end{array}$ & $\begin{array}{c}-14.97463 \\
(-2.207243)^{* *} \\
0.50\end{array}$ & $\begin{array}{c}3.183408 \\
(1.590479) \\
0.88\end{array}$ & $\begin{array}{c}3.497179 \\
(0.602960) \\
0.43\end{array}$ & $\begin{array}{c}12.21523 \\
(1.543078) \\
0.88\end{array}$ \\
\hline & \multicolumn{2}{|c|}{ Pre and post 1986} & \multicolumn{2}{|c|}{ Pre and post 1986} & \multicolumn{2}{|c|}{ Pre and post 1986} \\
\hline \multirow[t]{2}{*}{ SPAIN } & $\begin{array}{c}5.695366 \\
(0.836322) \\
0.63\end{array}$ & $\begin{array}{c}32.96219 \\
(4.046620) * * \\
0.71\end{array}$ & $\begin{array}{c}10.00614 \\
(1.909154) \\
0.66\end{array}$ & $\begin{array}{c}15.77499 \\
(2.045231)^{* *} \\
0.46\end{array}$ & $\begin{array}{c}8.400014 \\
(1.907078) \\
0.66\end{array}$ & $\begin{array}{c}\mathbf{- 3 7 . 6 1 5 6 0} \\
(-2.515769)^{* *} \\
\mathbf{0 . 5 3}\end{array}$ \\
\hline & \multicolumn{2}{|c|}{ Pre and post 1995} & \multicolumn{2}{|c|}{ Pre and post 1995} & \multicolumn{2}{|c|}{ Pre and post 1995} \\
\hline \multirow[t]{2}{*}{$S W E D E N$} & $\begin{array}{c}8.388829 \\
(1.330757) \\
0.49\end{array}$ & $\begin{array}{c}-227.46 \\
(-1.928767) \\
0.51\end{array}$ & $\begin{array}{c}0.791696 \\
(0.114246) \\
0.44\end{array}$ & $\begin{array}{c}56.03993 \\
(0.292495) \\
0.12\end{array}$ & $\begin{array}{c}-0.562267 \\
(-0.054189) \\
0.44\end{array}$ & $\begin{array}{c}-57.43373 \\
(-0.206592) \\
0.21\end{array}$ \\
\hline & \multicolumn{2}{|c|}{ Pre and post 1972} & Pre and & st 1972 & Pre and & ost 1972 \\
\hline$U K$ & $\begin{array}{c}5.456761 \\
(0.904903) \\
0.19\end{array}$ & $\begin{array}{c}2.033609 \\
(0.791264) \\
0.43\end{array}$ & $\begin{array}{c}2.622471 \\
(0.476300) \\
0.13\end{array}$ & $\begin{array}{c}3.059806 \\
(0.852587) \\
0.34\end{array}$ & $\begin{array}{c}9.971583 \\
(1.285992) \\
0.04\end{array}$ & $\begin{array}{c}4.926900 \\
(1.626751) \\
0.39\end{array}$ \\
\hline
\end{tabular}

*t-statistics in parentheses **t-statistics significant at the $5 \%$ level or less. Adjusted R-squared values below t-stats. Dependent variable is growth rate of real GDP for each country. Ho: FD significant in explaining growth. 
The main aim of the exercise in Table 7 is to illuminate the relationship between financial development and growth before and after accession to the EU. For this reason, the regressions are run for the period before and after the member country's accession to the EU. Several features stand out as a result of this exercise. In three cases (Greece, Sweden and the UK), financial development is not significant in explaining economic growth. It is more interesting, however, to study the sign on the coefficient on financial development before and after accession. The immediate finding is that in all the countries except the UK, there is a reversal in the sign of the coefficient in at least one of the proxies. For Finland, there is a very strong reversal of the coefficients on DCY and PCY, indicating that only after accession to the EU, did the credit process contributed positively to growth. Table 15 in the appendix shows the average growth rates for OECD countries over the period 1991-2003. Ireland has experienced the highest growth rates. Table 4 shows that the relationship between financial development and growth in Ireland is overwhelmingly significant and positive (DCY and DGDP) post-accession. The table also shows that before accession to the EU, Portugal had a resoundingly negative relationship between private sector credit and growth. Post 1986 this relationship although not significant becomes positive.

When Tables 6 and 7 are compared some very interesting conclusions can be made. Denmark shows a significantly negative relationship between financial integration and growth (after accession to the EU) when the link is studied through financial development. CAP has a significantly negative relationship with DGDP, and subsequently DGDP has a significantly negative relationship with the growth rate of real GDP. Spain on the other hand, displays a significant positive relationship between financial integration and growth through financial development. CAP has a significant positive relationship with DCY, and subsequently DCY has a significant positive relationship with the growth rate of real GDP. Although not significant, CAP has a negative relationship with DGDP, which then subsequently has a significant negative relationship with the growth rate of real GDP. Referring to Table 7, Spain shows an overwhelmingly positive relationship between financial development and growth: the coefficient signs on DCY and PCY are significant and positive.

Table 8: Panel Regressions Before and after Second Banking Directive

\begin{tabular}{|c|c|c|c|c|c|c|}
\hline & \multicolumn{2}{|c|}{ DCY } & \multicolumn{2}{|c|}{ PCY } & \multicolumn{2}{|c|}{ DGDP } \\
\hline $\begin{array}{l}\text { PANEL } \\
\text { REGRESSION }\end{array}$ & Pre and post & & Pre and pos & & Pre and post 19 & \\
\hline $\begin{array}{l}\text { WITH ALL } \\
\text { SAMPLE } \\
\text { MEMBERS }\end{array}$ & $\begin{array}{c}-2.907400 \\
(-1.975748) \\
0.37\end{array}$ & $\begin{array}{c}-0.420788 \\
(-0.234864) \\
0.66\end{array}$ & $\begin{array}{l}0.089571 \\
(0.055570) \\
0.36\end{array}$ & $\begin{array}{c}-0.479220 \\
(-0.309137) \\
0.66\end{array}$ & $\begin{array}{c}-12.56564 \\
(-2.295781)^{* * *} \\
0.23\end{array}$ & $\begin{array}{c}289.1119 \\
(1.934169) \\
0.29\end{array}$ \\
\hline $\begin{array}{l}\text { EXCEPT } 1995 \\
\text { MEMBERS }\end{array}$ & & & & & & \\
\hline
\end{tabular}


For the purposes of an overview of the robustness of the relationship between financial development and growth over the member countries in the sample that qualify, a panel regression was run on the period before and after 1989 (when the Second Banking Directive was implemented). The results (shown above in Table 8) indicate that all proxies for financial development register a negative relationship with growth after the institution of the Second Banking Directive. (These results mirror the results in Table 3 that show that financial development does not seem to benefit growth in the EU sample.) Moreover, there is a significant negative relationship between DGDP and economic growth. While this result is interesting it does not clarify the relationship. In order to see whether this relationship holds for all the countries across the sample, individual regressions are performed and the results are presented in Table 9 below.

\section{Table 9}

Linear regressions coefficients for financial development proxies (European Union countries based on Second Banking Directive)

\begin{tabular}{|c|c|c|c|c|c|c|}
\hline & \multicolumn{2}{|c|}{ DCY } & \multicolumn{2}{|c|}{ PCY } & \multicolumn{2}{|c|}{ DGDP } \\
\hline \multirow[b]{2}{*}{ DENMARK } & \multicolumn{2}{|c|}{ Pre and post 1989} & \multicolumn{2}{|c|}{ Pre and post 1989} & \multicolumn{2}{|c|}{ Pre and post 1989} \\
\hline & $\begin{array}{c}-8.013725 \\
(-8.015513) \\
0.35\end{array}$ & $\begin{array}{c}-3.196521 \\
(-0.451050) \\
0.07\end{array}$ & $\begin{array}{c}-2.598929 \\
(-0.222638) \\
0.37\end{array}$ & $\begin{array}{c}-3.799983 \\
(-0.726388) \\
0.03\end{array}$ & $\begin{array}{c}-16.90822 \\
(-1.938709) \\
0.40\end{array}$ & $\begin{array}{c}-40.09909 \\
(-3.009733) * * \\
0.52\end{array}$ \\
\hline & \multicolumn{2}{|c|}{ Pre and post 1989} & \multicolumn{2}{|c|}{ Pre and post 1989} & \multicolumn{2}{|c|}{ Pre and post 1989} \\
\hline \multirow[t]{2}{*}{ GREECE } & $\begin{array}{c}0.838059 \\
(0.207814) \\
0.53\end{array}$ & $\begin{array}{c}-12.94277 \\
(-2.777187)^{* * *} \\
0.74\end{array}$ & $\begin{array}{c}7.378897 \\
(0.835530) \\
0.53\end{array}$ & $\begin{array}{c}18.03245 \\
0.760889 \\
0.49\end{array}$ & $\begin{array}{c}3.518014 \\
(0.557259) \\
0.53\end{array}$ & $\begin{array}{c}7.726984 \\
(0.426670) \\
0.46\end{array}$ \\
\hline & \multicolumn{2}{|c|}{ Pre and post 1989} & \multicolumn{2}{|c|}{ Pre and post 1989} & \multicolumn{2}{|c|}{ Pre and post 1989} \\
\hline \multirow[t]{2}{*}{ IRELAND } & $\begin{array}{c}-6.873298 \\
(-1.066667) \\
0.06\end{array}$ & $\begin{array}{c}21.71970 \\
(2.608062) * * \\
0.72\end{array}$ & $\begin{array}{c}0.021898 \\
(0.001417) \\
0.10\end{array}$ & $\begin{array}{c}21.27247 \\
(2.444901) * * \\
0.70)\end{array}$ & $\begin{array}{c}11.73246 \\
(1.214199) \\
0.05\end{array}$ & $\begin{array}{c}16.25064 \\
(1.022712) \\
0.52\end{array}$ \\
\hline & \multicolumn{2}{|c|}{ Pre and post 1989} & \multicolumn{2}{|c|}{ Pre and post 1989} & \multicolumn{2}{|c|}{ Pre and post 1989} \\
\hline \multirow[t]{2}{*}{ PORTUGAL } & $\begin{array}{c}-7.818762 \\
(-1.281666) \\
0.46\end{array}$ & $\begin{array}{c}-0.921854 \\
(0.096532) \\
0.79\end{array}$ & $\begin{array}{c}-5.917097 \\
(-1.300486) \\
0.46\end{array}$ & $\begin{array}{c}-0.475273 \\
(-0.072478) \\
0.79\end{array}$ & $\begin{array}{c}3.457533 \\
(0.627100) \\
0.44\end{array}$ & $\begin{array}{c}8.488066 \\
(0.429898) \\
0.79\end{array}$ \\
\hline & \multicolumn{2}{|c|}{ Pre and post 1989} & \multicolumn{2}{|c|}{ Pre and post 1989} & \multicolumn{2}{|c|}{ Pre and post 1989} \\
\hline \multirow[t]{2}{*}{ SPAIN } & $\begin{array}{c}9.651445 \\
(1.515739) \\
0.60\end{array}$ & $\begin{array}{c}15.63821 \\
(2.624414)^{* *} \\
0.90\end{array}$ & $\begin{array}{c}9.698833 \\
(1.890698) \\
0.61\end{array}$ & $\begin{array}{c}5.361210 \\
(1.152722) \\
0.84\end{array}$ & $\begin{array}{c}7.195187 \\
(1.581969) \\
0.60\end{array}$ & $\begin{array}{c}-5.589353 \\
(-0.455833) \\
0.81\end{array}$ \\
\hline & \multicolumn{2}{|c|}{ Pre and post 1989} & \multicolumn{2}{|c|}{ Pre and post 1989} & \multicolumn{2}{|c|}{ Pre and post 1989} \\
\hline$U K$ & $\begin{array}{c}2.952366 \\
(1.298475) \\
0.30\end{array}$ & $\begin{array}{c}-18.26996 \\
(-1.104231) \\
0.63\end{array}$ & $\begin{array}{c}3.259002 \\
(1.349702) \\
0.30\end{array}$ & $\begin{array}{c}-6.671244 \\
(-0.501594) \\
0.58\end{array}$ & $\begin{array}{c}3.260397 \\
(1.199726) \\
0.29\end{array}$ & $\begin{array}{c}9.971277 \\
(1.749731) \\
0.70\end{array}$ \\
\hline
\end{tabular}

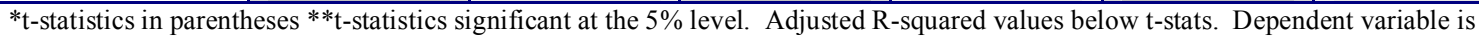
growth rate of real GDP for each country. 
Table 9 provides some interesting insights into the relationship between financial development and growth before and after the Second Banking Directive. The regressions are performed only for the six countries that were already members before 1989. In Denmark's case, financial development displays an overwhelmingly negative relationship with growth regardless of the time period being studied. Both after joining the EU and after 1989, the relationship between DGDP and growth is significantly negative. In Table 7, the financial development proxies are not significant for Greece before and after 1981 when it joined the EU. Table 9 makes this relationship a little clearer. Post-1989, the relationship between DCY and growth is resoundingly negative for Greece. Table 7 shows that PCY and DGDP are significant and positive for Ireland in the post-1973 period. The results are robust for post-1989 period, and DCY is now also positive and significant. Spain displays an overwhelmingly positive relationship between the proxies and growth rates, and the results are robust to the post 1989 period. Overall, then for the six countries in the second sample, Denmark displays the most overwhelmingly negative relationship between financial development and growth, regardless of the proxy chosen.

Post-1989, DCY and PCY have a negative relationship with growth in the UK. As discussed earlier, financial integration has a negative effect on financial development in the UK post-1989. Table 10 below shows that the average net capital inflow into the UK is positive. Table 1 showed that PCY has increased on average over $400 \%$ in the UK. It seems then that financial integration and financial development have a negative effect on growth in the UK, because net capital flows are positive at 3\% of GDP, domestic credit and private sector credit are not being channeled to investment in the UK, but instead finance projects outside of the UK. The UK is then acting as a net lender of funds in the EU.

Table 10

\begin{tabular}{|c|l|}
\hline Country & $\begin{array}{c}\text { Average net funds flow to } \\
\text { banking sector (1991- } \\
\text { 2000) as a fraction of GDP }\end{array}$ \\
\hline Denmark & -0.00445398 \\
\hline Greece & 0.026346 \\
\hline Ireland & -0.03787 \\
\hline Portugal & 0.03029532 \\
\hline Spain & 0.006365653 \\
\hline UK & 0.032828 \\
\hline Switzerland* & 0.00481347 \\
\hline
\end{tabular}

*Switzerland acts as a control 


\section{Robustness}

In addition to the analysis in Table 8 in section 5, two main robustness checks are performed. The analysis of financial integration on financial development is carried out postSecond-Banking-Directive to see if the results change. Secondly, structural break tests are performed to test for structural breaks in the financial development proxies at the time of accession to the EU.

Table 11: Results of Linear Regressions of Financial Integration on Financial

\section{Development}

\begin{tabular}{|c|l|l|l|l|l|l|}
\hline \multicolumn{7}{|c|}{ Financial Integration and Financial Development } \\
\hline & $\begin{array}{l}\text { DENMARK } \\
\text { Post-1989 }\end{array}$ & $\begin{array}{l}\text { GREECE } \\
\text { Post 1989 }\end{array}$ & $\begin{array}{l}\text { IRELAND } \\
\text { Post-1989 }\end{array}$ & $\begin{array}{l}\text { PORTUGAL } \\
\text { Post-1989 }\end{array}$ & $\begin{array}{l}\text { SPAIN } \\
\text { Post-1989 }\end{array}$ & $\begin{array}{l}\text { UK } \\
\text { Post-1989 }\end{array}$ \\
\hline DCY & -0.832592 & 1.804018 & 0.239078 & 0.130334 & $\mathbf{0 . 4 4 8 4 0 9}$ & -0.191458 \\
& $(-1.642368)$ & $(1.731917)$ & $(0.532604)$ & $(0.250565)$ & $\mathbf{( 2 . 0 8 5 4 0 1 ) * *}$ & $(-1.288916)$ \\
& 0.92 & 0.03 & 0.83 & 0.89 & $\mathbf{0 . 3 8}$ & 0.87 \\
\hline PCY & -1.134791 & 0.329867 & 0.221237 & -0.021868 & 0.286612 & -0.047865 \\
& $(-1.708307)$ & $(1.038948)$ & $(0.498086)$ & $(-0.028733)$ & $(0.651679)$ & $(-0.219480)$ \\
& 0.89 & 0.88 & 0.85 & 0.90 & 0.31 & 0.78 \\
\hline DGDP & $\mathbf{- 0 . 3 4 0 7 6 6}$ & 0.116681 & -0.034735 & 0.083853 & -0.027235 & -0.263801 \\
& $\mathbf{( - 2 . 0 1 5 0 8 2 ) * * *}$ & $(0.256042)$ & $(-0.110606)$ & $(0.338685)$ & $(-0.147701)$ & $(-0.625169)$ \\
& $\mathbf{0 . 5 7}$ & 0.43 & 0.89 & 0.88 & 0.59 & 0.88 \\
\hline
\end{tabular}

*t-statistics in parentheses **t-statistics significant at $5 \%$ or less. Adjusted R-squared values below t-stats. Dependent variable is FD.

Table 11 displays the results of the robustness check on the relationship between CAP and the proxies for financial development. The results indicate that the relationships are robust to the Second Banking Directive.

Chow tests are performed to see whether structural tests occur during two key dates - the date of accession to the European Union and the date of the Second Banking Directive. In order to remove the secular trend across the entire EU, the average of each proxy is taken across the sample period for all countries in the sample and including Switzerland, and then this average is subtracted from the proxy series for each country. Tables 12 to 14 present the Chow tests results for the three proxies for each of the countries in the sample, and are in the appendix. In the case of the three countries that joined in 1995, Chow tests are not carried out for 1989.

Austria, Finland and Portugal show evidence of structural breaks occurring at the time of accession regardless of the financial proxy tested. Denmark, Ireland, Spain and the UK do not show evidence of structural breaks with any of the proxies tested. 


\section{Conclusion}

Many studies look at the relationship between financial development and growth. Some of the current issues in this literature include the choice of proxy and the causality between financial development and growth. This paper looks at the relationship from a European Union perspective, and in an innovative approach, considers the effect of financial integration on growth through the financial development channel in a comparative study across a sample of EU countries.

The basic approach follows that of De Gregorio, in that the study follows a two-stage procedure. First the effect of financial integration on financial development is assessed, and thereafter the effect of financial development on growth is assessed. Three financial development proxies are chosen and tested - the ratio of domestic credit provided by the local banking sector to GDP, the ratio of private sector credit provided by the local banking sector to GDP, and the ratio of domestic deposits in the domestic banking sector to GDP. Financial integration is measured as the net flows of funds to the banking sector in the form of deposits and currency relative to GDP.

The paper finds several interesting conclusions, and highlights several puzzles that beg further study. Financial integration does not seem to lead to a general overall increase in the relative size of the financial sector. Secondly, while panel regressions display an overwhelmingly negative effect of financial development on growth, this result changes somewhat when the analysis is country-focused. The relationship between financial development and growth is not uniform among the countries studied. The author hastens to add that this may reflect upon the choice of proxies, which although standard, are by no means considered to be excellent in capturing the speed and nature of financial development. Contrary also to expectations, the path of financial development is not impacted in any definite pattern. Most of the countries do, however, display a reversal in the nature of the relationship.

Some definite conclusions can be made with respect to specific countries. Overall, financial and economic integration do not seem to have benefited Denmark, when the relationship is studied through the financial development channel. A study of the average growth rates for these countries over the last decade shows that Denmark is on the lower end of the spectrum of growth rates for the OECD countries. While there is no definitive evidence that financial integration positively impacts financial development or growth, there is no doubt that financial development has contributed to the great growth surge experienced in Ireland and Spain over the last decade. Interestingly Switzerland has experienced the lowest average growth rates out of the OECD countries over the last decade, indicating that there may be some benefit to be garnered from joining the European Union.

Financial integration and financial development have played a key role in the high growth rates achieved by countries like Ireland and Spain. The UK seems to channel a significant level of private credit outside of its own borders and this has lessened the impact of financial development on its own economy. Reflecting the lack of uniform development, financial integration and financial development do not seem to have any positive impact on Denmark, which is on the lower end of the spectrum of growth in the EU. Overall, the results of the analysis on financial integration seem to support the conclusion made by De Gregorio. There does not seem to be any direct evidence of financial integration on economic growth after controlling for financial depth.

Finally, in a surprising turn of events, the evidence shows that free banking (the lifting of regulations on bank operations across country borders) did not have a significant impact on the nature of the relationship for most of the countries. The overall findings in this paper support the hypothesis that some countries are benefiting more than other as a result of financial and economic integration. The study concludes with the conclusion of an overwhelming puzzle - the 
overall relationship between financial development and growth does not change with the advent of free banking. Further research is needed to better understand and qualify this puzzle.

\section{Literature Cited}

Agénor, P., "Benefits and Costs of International Financial Integration: Theory and Facts", (2002) Working Paper, The World Bank.

Asdrubali, P., Bent Sorensen and Oved Yosha (1996), "Channels of Interstate Risk-Sharing: United States 1963-1990, Quarterly Journal of Economics 111, pp. 1081-1110.

Barro, R.J., (1991), "Economic Growth in a Cross Section of Countries", Quarterly Journal of Economics, 104: 407-433.

Caprio, G. and Patrick Honohan (1999), "Restoring Banking Stability: Beyond Supervised Capital Requirements", Journal of Economic Perspectives, 13, pp. 43-64.

Cole, H. L., and Maurice Obstfeld (1991) "Commodity Trade and International Risk Sharing: How Much Do Financial Markets Matter?”, Journal of Monetary Economics, August, 28(1), pp. 3-24.

De Gregorio, J., "Financial Integration, Financial Development and Economic Growth", (1999), Estudios de Economia, December, 26(2), pp. 137-61.

De Gregorio, J., and P. Guidotti, (1995) "Financial Development and Economic Growth", World Development, vol. 23, issue 3, pp. 433-448

Devereaux, M.B., and Gregor W. Smith, "International Risk Sharing and Economic Growth", (1994), International Economic Review, Vol. 35, No. 3 (August), pp. 535-550.

Diamond, D. W., and Philip H. Dybvig, (1983), "Bank Runs, Deposit Insurance and Liquidity", Journal of Political Economy, June, 91(3), pp. 104-19.

Economic and Financial Committee (2002), "Report by the Economic and Financial Committee (EFC) on EU Financial Integration", European Economy, European Commission Economic Papers No. 171.

European Commission (2001) "The EU Economy 2001 Review", Directorate General for Economic and Financial Affairs.

Field, G., M. Humphreys and D. Sokolov (2000), Euroland,, Integrating European Capital Markets, London, UK: Euromoney Books.

Gelb, A. H., "Financial Policies, Growth, and Efficiency", 1989, Working Papers, The World Bank; Country Economics Department, Policy Research and External Affairs.

Greenwood and Jovanovic (1990), "Financial Development, Growth and the Distribution of Income” Journal of Political Economy, October, Part 1, 98(5), 1076-1107. 
Giannetti, M. and Steven Ongena (2005), "Financial Integration and Entrepreneurial Activity", CEPR Discussion Paper No. 5151.

Guiso, L., Tullio Jappelli, Mario Padula, and Marco Pagano, "Financial Market Integration and Economic Growth in the EU, (2004), Working Paper, Centro Studi in Economia E Finanza.

Hadjiemmanuil, C., "The European Central Bank and Banking Supervision", (1996), Essays in International Financial and Economic Law, No. 3, September.

Ibanez, D. M., and Phil Molyneux, (2002) "Integration of European Banking and Financial Markets" EIFC - Technology and Finance Working Papers 14, United Nations University, Institute for New Technologies.

Kalemli-Ozcan, S., Bent Sorensen and Oved Yosha, (2001) "Economic Integration, Industrial Specialization, and the Asymmetry of Macroeconomic Fluctuations" Journal of International Economics, 55 (1), pp. 107-37.

Karlinger, L., "The Impact of Common Currencies on Financial Market: A Literature Review and Evidence from the Euro Area", (2002), Working Paper, Bank of Canada.

King, R.G. and Levine R. (1993a). "Finance and Growth: Schumpeter Might Be Right", Quarterly Journal of Economics, 108 (3), 717-737.

King, R.G. and Levine, R. (1993b). "Finance, Entrepreneurship, and Growth: Theory and Evidence", Journal of Monetary Economics, 32 (3), 513-542.

Levine, R. (1996) "Foreign Banks, Financial Development and Economic Growth", in International Financial Markets, ed. By Claude E. Barfield, American Enterprise Institute Press, Washington D.C.

Lucas, R. (1987) Models of Business Cycle, Oxford, Blackwell.

Melitz, J. and F. Zumer (1999), "Interregional and International Risk Sharing and Lessons for EMU” CEPR Discussions Paper No. 2154.

Mongelli, F.P. (2002) "'New' Views on the Optimum Currency Area Theory: What is EMU Telling Us?” ECB Working Paper No. 138.

OECD World Factbook, 2005. March, OECD.

Obstfeld, M., "Risk-Taking, Globalization, and Growth", (1994), American Economic Review, 84, pp. 1310-1329.

Pedroni, P. (2000) "Fully Modified OLS for Heterogeneous Cointegrated Panels" in Nonstationary Panels, Panel Cointegration and Dynamic Panels, Elsevier Science Inc., 15, 93-130.

Phillips, C.B, and H.R. Moon, "Linear Regression Limit Theory for Nonstationary Panel Data", Econometrica, Vol. 67, No. 5, September, 1999, pp.1057-1111. 
Saint-Paul, G. (1992) “Technological Choice, Financial Markets and Economic Development, European Economic Review, May, 36(4), 763-81.

Scheller, H., "The European Central Bank: History, Role and Functions", (2004), The European Central Bank, Frankfurt, Germany.

Thiel, M. (2001) "Finance and Growth - A Review of Theory and the Available Evidence" European Commission, DG ECFIN Economic Paper No. 158. 


\section{Appendix 1}

De Gregorio (1999) presents a dynamic two-country, two-agent, two-good model. The countries are A and B, and the goods are 1 and 2. Country A produces $\mathrm{x}$ amount of good 1 , and $\mathrm{y}$ amount of good 2. Country B produces $x^{*}$ amount of good 1, and $y^{*}$ amount of good 2. In the case where there is no specialization between the countries, country A produces $\mathrm{x}=\mathrm{q}$ and $\mathrm{y}=1-\mathrm{q}$. Country B produces $x^{*}=q$ and $y^{*}=1-q$, where $\mathrm{q}>0.5$. Therefore the assumption is that production of each good is unitary and that country $i$ is more efficient at good $i$. The two countries can benefit from specialization through economies of scale such that if country A specializes in good 1 , it can produce $\mathrm{x}=\mathrm{Q}>1$, while country $\mathrm{B}$ could produce $\mathrm{y}^{*}=\mathrm{Q}$ of $\operatorname{good} 2$.

The household agents own the firm, and reap the dividends from the production by firms. In period 1, consumers engage in asset trading, and production occurs. Consumer preferences are realized in period 2 , and either good (each with probability 0.5 ) is demanded. The utility function for the consumption of $\mathrm{g}$ amount of either good is denoted as $\mathrm{u}(\mathrm{g})$.

In a closed economy setting, with specialization, country A will produce Q amount of good 1, and very little, if any, of good 2. Normalizing the number of consumers to 1 , the expected utility function is as below:

$$
U_{a}=[u(Q)+u(0)] / 2
$$

If there is local diversification, however, the utility function will take the form of equation (2) below:

$$
U_{b}=[u(q)+u(1-q)] / 2
$$

De Gregorio points out that under the standard concavity of the utility function, and the existence of scale economies, countries will not specialize and so the representative consumer's expected utility function will be given by equation (2).

Under the assumption of an open economy, households can diversify and hold shares in foreign companies outside of the domestic borders. These shares are denoted s. Shares held in domestic firms are denoted (1-s). Expected utility then takes the form below:

$$
U_{c}=\left[u\left(s x+(1-s) x^{*}\right)+u\left(s y+(1-s) y^{*}\right)\right] / 2
$$

De Gregorio then emphasizes two results: countries specialize to maximize production, and thus $\mathrm{x}=\mathrm{Q}, \mathrm{y}^{*}=\mathrm{Q}$, and $\mathrm{x}^{*}=\mathrm{y}=0$. Secondly the representative consumer holds a balanced portfolio with $\mathrm{s}=0.5$. The utility function is then

$$
U_{c}=[u(Q / 2)+u(Q / 2)] / 2
$$

which is greater than $U_{a}$ or $U_{b}$. The general result is then $U_{c}>U_{b}>U_{a}$.

The main conclusions from the model are that representative consumers can smooth consumption across time when they can trade in international assets, and secondly the inability of consumers to 
protect themselves against risk through international asset trading leads to sub-optimal specialization. International risk sharing then leads to a lower variance of consumption: it is $\left(q-\frac{1}{2}\right)^{2}$ in a closed economy but 0 in an open economy. There is also a production effect that increases consumption from 0.5 in a closed economy to $\mathrm{Q} / 2$ in the open economy. Through calibration, De Gregorio goes on to show that countries that stand to gain most from international risk-sharing are developing countries, and that the main reason for these large welfare gains is full financial integration. 


\section{Appendix 2}

Table 12: Chow Tests for Structural Breaks - DCY

\begin{tabular}{|c|c|c|c|c|c|c|c|c|c|c|c|c|c|c|c|}
\hline & AUSTRIA & \multicolumn{2}{|c|}{ DENMARK } & FINLAND & \multicolumn{2}{|c|}{ GREECE } & \multicolumn{2}{|c|}{ IRELAND } & \multicolumn{2}{l|}{ PORTUGAL } & \multicolumn{2}{|c|}{ SPAIN } & SWEDEN & \multicolumn{2}{|c|}{ UK } \\
\hline $\boldsymbol{T B}$ & 1995 & 1973 & 1989 & 1995 & 1981 & 1989 & 1973 & 1989 & 1986 & 1989 & 1986 & 1989 & 1995 & 1973 & 1989 \\
\hline $\boldsymbol{f}$-stat & $\mathbf{4 . 8 2 7}$ & 1.299 & 2.122 & $\mathbf{5 . 2 5 1}$ & 1.913 & 1.501 & 0.516 & 0.552 & $\mathbf{8 . 3 6 9}$ & 0.290 & 2.051 & 1.810 & 1.315 & 0.937 & 3.202 \\
\hline $\begin{array}{c}\boldsymbol{p} \text { - } \\
\text { value }\end{array}$ & $\mathbf{0 . 0 1 2}$ & 0.283 & 0.131 & $\mathbf{0 . 0 0 9}$ & 0.159 & 0.234 & 0.600 & 0.579 & $\mathbf{0 . 0 0 1}$ & 0.749 & 0.140 & 0.175 & 0.278 & 0.399 & 0.049 \\
\hline
\end{tabular}

Table 13: Chow Tests for Structural Breaks - PCY

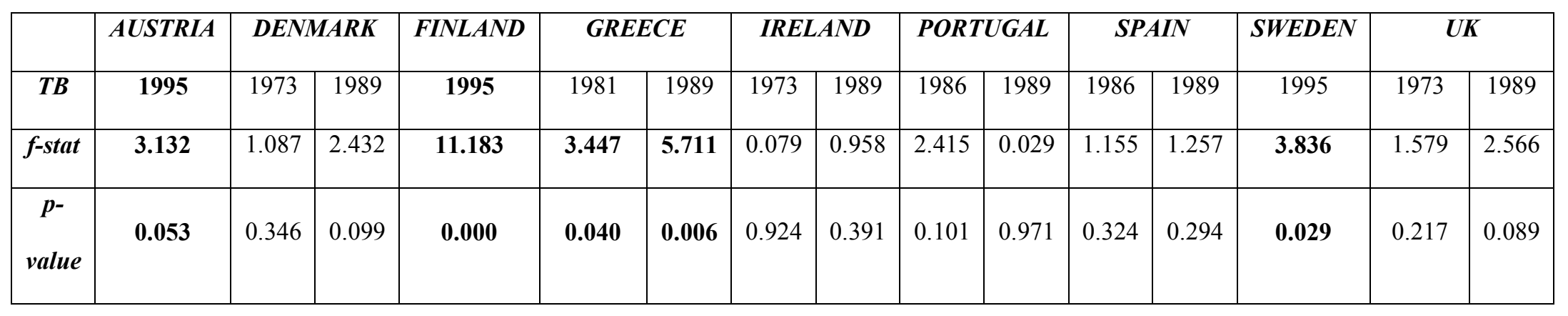


Table 14: Chow Tests for Structural Breaks - DGDP

\begin{tabular}{|c|c|c|c|c|c|c|c|c|c|c|c|c|c|c|c|}
\hline & AUSTRIA & \multicolumn{2}{|c|}{ DENMARK } & FINLAND & \multicolumn{2}{|c|}{ GREECE } & \multicolumn{2}{|c|}{ IRELAND } & \multicolumn{2}{l|}{ PORTUGAL } & \multicolumn{2}{|c|}{ SPAIN } & \multicolumn{2}{l|}{ SWEDEN } & \multicolumn{2}{|c|}{ UK } \\
\hline $\boldsymbol{T B}$ & 1995 & 1973 & 1989 & 1995 & 1981 & 1989 & 1973 & 1989 & 1986 & 1989 & 1986 & 1989 & 1995 & 1973 & 1989 \\
\hline $\boldsymbol{f}$-stat & $\mathbf{4 . 4 4 9}$ & 0.549 & 0.223 & $\mathbf{7 . 9 3 9}$ & 0.241 & $\mathbf{3 . 8 7 9}$ & 0.116 & 2.811 & $\mathbf{5 . 8 7 2}$ & 0.138 & 1.122 & 0.744 & 1.409 & 1.234 & 0.871 \\
\hline $\begin{array}{c}\boldsymbol{p} \text { - } \\
\text { value }\end{array}$ & $\mathbf{0 . 0 1 7}$ & 0.581 & 0.801 & $\mathbf{0 . 0 0 1}$ & 0.787 & $\mathbf{0 . 0 2 7}$ & 0.890 & 0.071 & $\mathbf{0 . 0 0 5}$ & 0.872 & 0.334 & 0.481 & 0.255 & 0.301 & 0.425 \\
\hline
\end{tabular}




\section{Appendix 3}

Table 15: Growth Rates of Real GDP, Average Annual Growth in Percentage, 1991-2003.

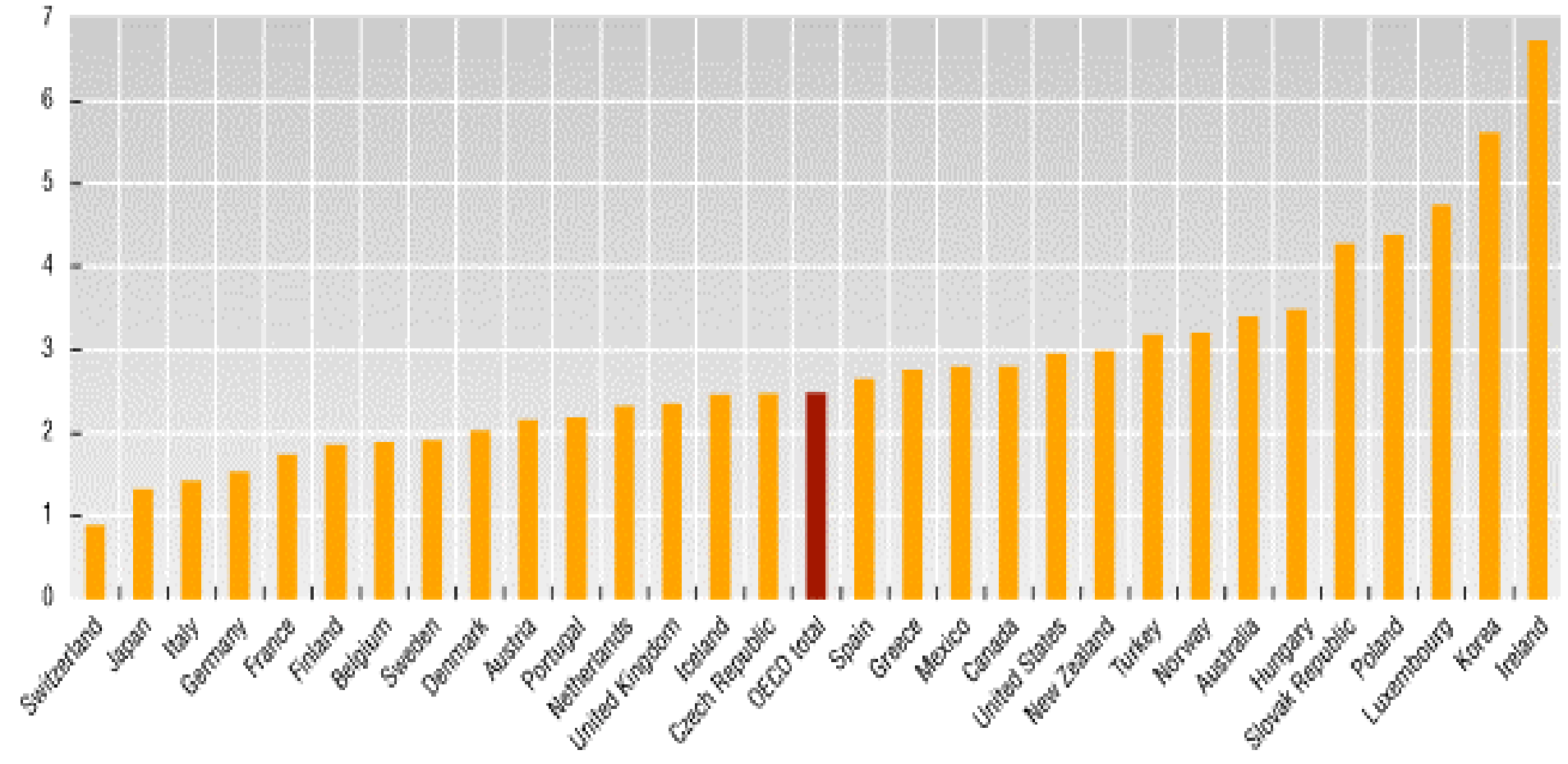

Source: OECD World Factbook, 2005. 


\section{Appendix 4 - Net flows of funds in the form of deposits and currency relative to GDP}
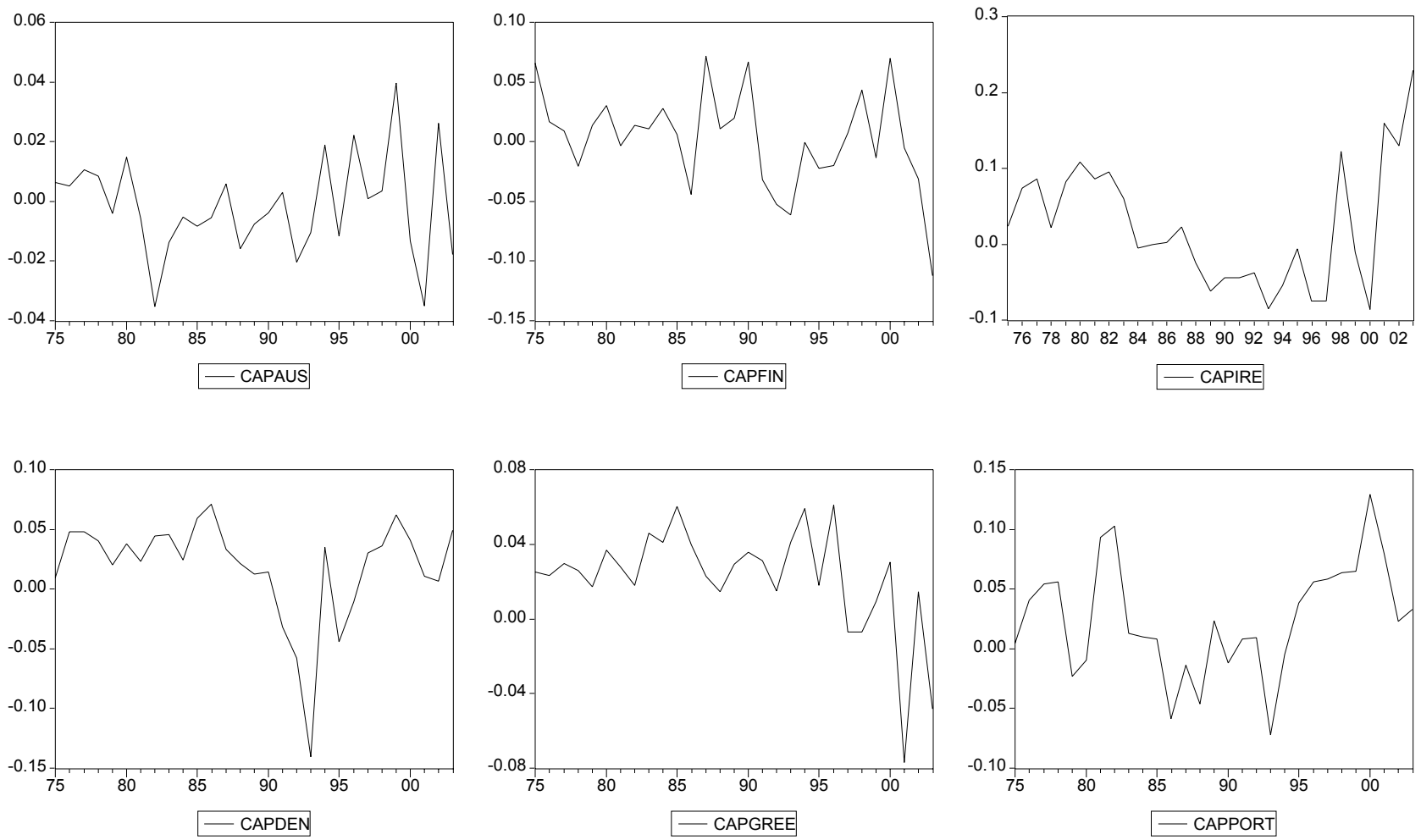
Appendix 4 continued.
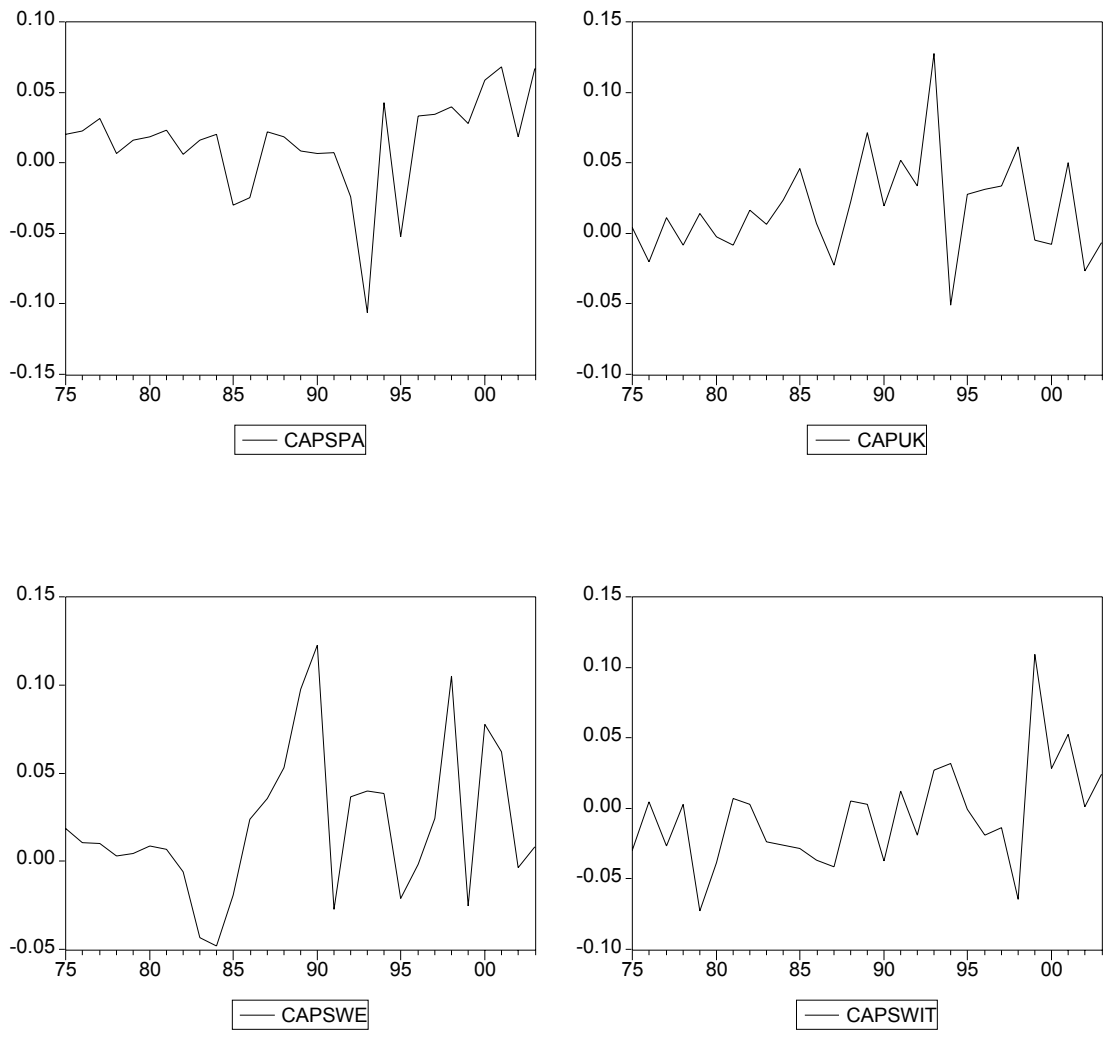